Universidad de Lima

Facultad de Comunicación

Carrera de Comunicación

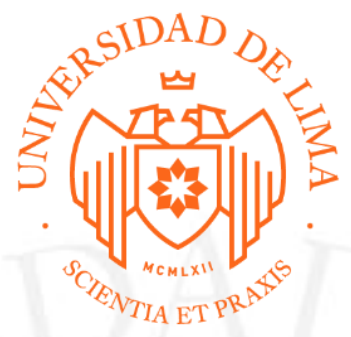

\title{
LOS "YOUTUBERS" COMO MODALIDAD EMERGENTE DE PRODUCCIÓN AUDIOVISUAL EN EL PERÚ
}

Tesis para optar el Título Profesional de Licenciado en Comunicación

\section{Jose Ramon Osorio Bazan \\ Código 20070792}

\section{Asesor}

Alberto Matsuura Sonoda

$$
\text { Lima - Perú }
$$

Febrero de 2020 


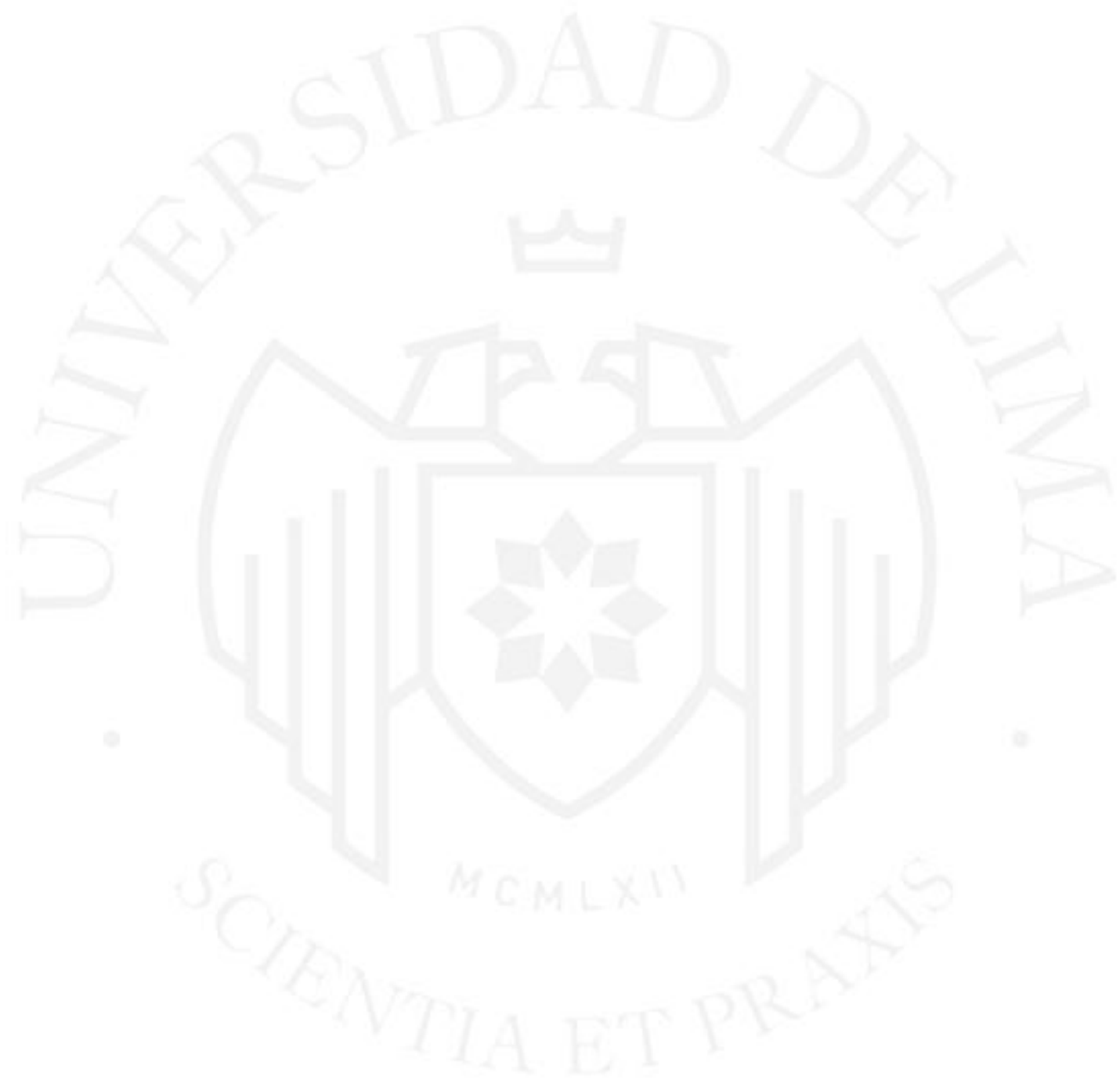




\section{LOS "YOUTUBERS" COMO MODALIDAD EMERGENTE DE PRODUCCIÓN AUDIOVISUAL EN EL PERÚ}


INTRODUCCIÓN .......................................................................................................1

CAPÍTULO I: MARCO TEÓRICO .....................................................................2

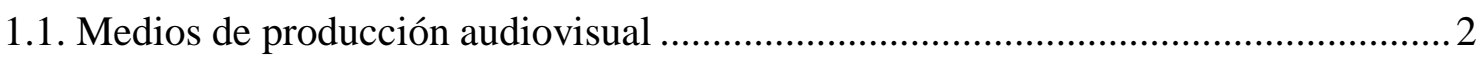

1.1.1. Definición y origen del concepto audiovisual ..................................................2

1.1.2. Etapas de la realización audiovisual................................................................ 3

1.1.3. Avances tecnológicos dentro del mundo audiovisual ........................................ 4

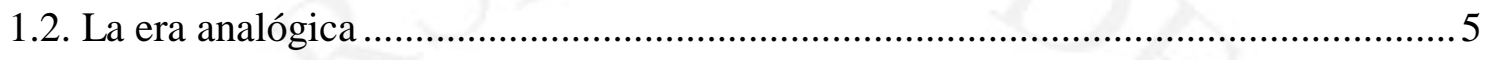

1.3. La era digital: la emergencia de una revolución ................................................ 6

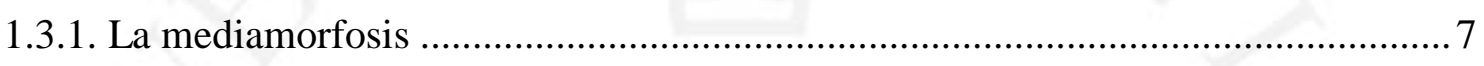

1.4. El fenómeno de los "youtubers" ................................................................ 8

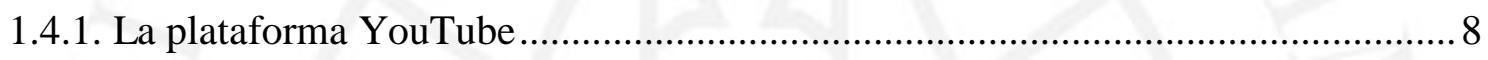

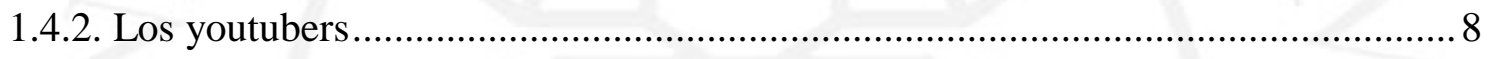

1.4.3. Los youtubers desde una perspectiva comunicacional ...................................... 9

1.4.4. Los youtubers como modalidad emergente de producción audiovisual ................ 10

1.4.5. Comparación entre la producción audiovisual tradicional y la producción

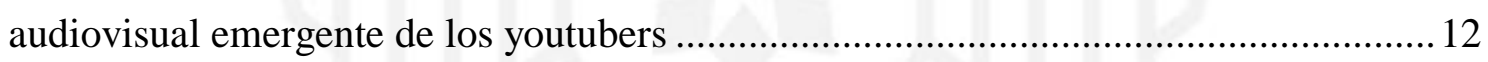

CAPÍTULO II: METODOLOGÍA _.......................................................................... 17

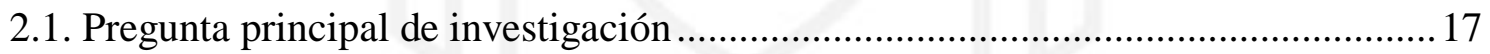

2.2. Preguntas específicas de investigación .............................................................. 17

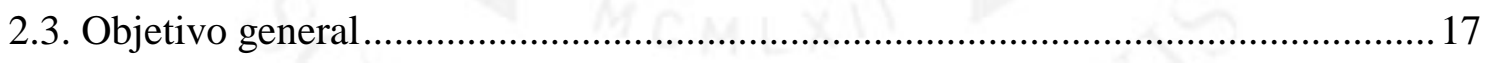

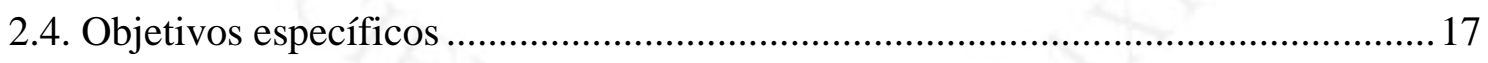

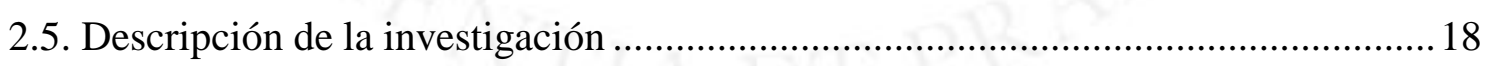

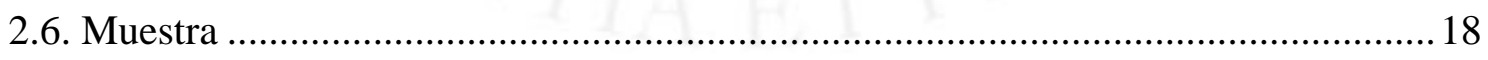

2.7. Técnica e instrumento de recolección de datos.................................................... 18

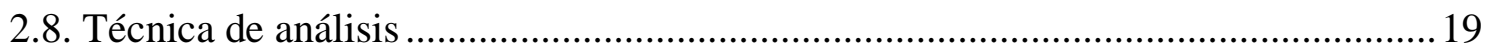

CAPÍTULO III: RESULTADOS .................................................................................. 20

3.1. ¿Cuáles son las características de los medios de producción audiovisual en la era digital y en el contexto peruano?

3.2. ¿Cómo se caracteriza el fenómeno youtubers desde una perspectiva comunicacional? 
3.3. ¿De qué manera influyen los youtubers como modalidad emergente de producción

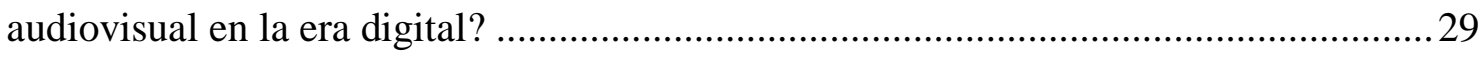

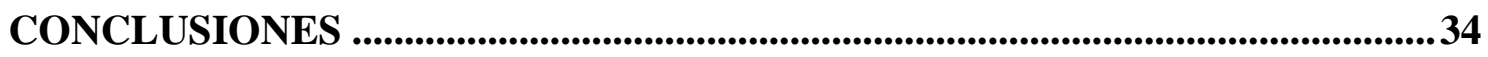

RECOMENDACIONES …......................................................................................38

REFERENCIAS .........................................................................................................39

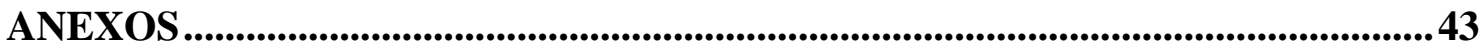




\section{ÍNDICE DE TABLAS}

Tabla 3.1. Características de YouTube en comparación con los medios tradicionales de comunicación 20

Tabla 3.2. Hegemonía de medios de comunicación digital. 22

Tabla 3.3. Valores de producción de los youtubers entrevistados .23

Tabla 3.4. ¿Cómo se caracteriza el fenómeno youtubers desde una perspectiva comunicacional? .27

Tabla 3.5. El youtuber como modalidad emergente de producción audiovisual 30 


\section{ÍNDICE DE FIGURAS}

Figura 1.1. Línea del tiempo de los medios de comunicación....................................... 4 


\section{RESUMEN}

La presente investigación tuvo como objetivo general analizar a los youtubers como modalidad emergente de producción audiovisual en el Perú. Para ello, se trabajó sobre la base del enfoque cualitativo. La muestra del estudio estuvo compuesta por un productor audiovisual, un analista de medios digitales y tres youtubers peruanos; como instrumento de recolección de datos, se utilizó la guía de entrevista. En cuanto a las conclusiones, se destaca cómo los medios digitales siguen las mismas etapas de producción que los medios tradicionales, pero de forma menos rígida y profesional; es así que se obtienen resultados económicos incipientes para el primer grupo. Sin embargo, la interactividad del medio digital y la preferencia del público joven hacia este, ha obligado a los medios tradicionales a transformarse y adaptarse progresivamente; y Perú no ha sido ajeno a esa situación.

Palabras clave: YouTube, youtubers, medios tradicionales, televisión, producción audiovisual, modalidad emergente. 


\begin{abstract}
The purpose of this research was to analyze youtubers as an emerging modality of audiovisual production in Peru. For this, we worked on the basis of the qualitative approach. The study sample was composed of an audiovisual producer, a digital media analyst and three Peruvian youtubers; the interview guide was used as an instrument for data collection. Regarding the conclusions, it is highlighted how digital media follow the same stages of production as traditional media, but in a less rigid and professional way; thus, incipient economic results are obtained for the first group. However, the interactivity that brings the digital platforms and the preference of the young target towards it, has forced the traditional media to transform and adapt progressively; and Peru has not been oblivious to that situation.
\end{abstract}

Keywords: YouTube, youtubers, traditional media, television, audiovisual production, emerging mode. 


\section{INTRODUCCIÓN}

El desarrollo de las nuevas tecnologías de información y comunicación, así como el impacto de las mismas, tienen una cualidad multidimensional, en tanto producen efectos en todos los ámbitos de la vida humana. Es el caso de la creación YouTube y otras plataformas virtuales, abren un gigantesco abanico de alternativas y espacios de creación y comunicación, y, a su vez, impulsan notables cambios en los ámbitos sociales, económicos y culturales.

La presente investigación se propuso analizar el fenómeno de los youtubers, con el fin de establecer si se puede considerar como una modalidad emergente de producción audiovisual en el contexto de la era digital y la sociedad del conocimiento. A tal efecto, se identifican los rasgos identitarios de los medios digitales y tradicionales, y se analiza la participación de los youtubers en los procesos de comunicación y producción audiovisual para el caso peruano.

Con el motivo de lograr los objetivos trazados, en el capítulo I de la presente estructura de la investigación, se desarrolló el marco teórico a partir de tres categorías analíticas y organizadoras: la era digital, el fenómeno de los youtubers y la producción individual. En segundo lugar, se presentó el capítulo II que está compuesto por los siguientes aspectos: preguntas y objetivos de investigación, el diseño de investigación, la muestra y las técnicas de recolección y análisis de datos.

Como siguiente etapa de la estructura de la investigación, se incluyó el capítulo III, referido a la exposición de los resultados de investigación en arreglo a las preguntas y los objetivos de la misma. Asimismo, se presentó una descripción detallada del análisis interpretativo de los contenidos de las entrevistas a productores audiovisuales y youtubers, el cual se enfocó en realizar una contrastación entre las formas tradicionales de producción audiovisual y la modalidad emergente representada por el youtuber. El trabajo cierra con la síntesis de las respuestas a las preguntas y objetivos de investigación, desarrollada mediante la formulación de conclusiones y recomendaciones. 


\section{CAPÍTULO I: MARCO TEÓRICO}

El primer capítulo establece los fundamentos teóricos del presente estudio. En el mismo, se precisan las conceptualizaciones referidas a los youtubers como modalidades novedosas de producción audiovisual en el contexto de una era marcada por la digitalización.

\subsection{Medios de producción audiovisual}

\subsubsection{Definición y origen del concepto audiovisual}

El concepto audiovisual comienza a tener auge en Estados Unidos alrededor de los años 30, luego de que aparece el cine sonoro. Similarmente, este término comienza a usarse de manera frecuente en Francia en los años 50 para hacer referencia a las técnicas de difusión simultáneas. Es entonces cuando el término comienza a ampliarse y utilizarse de manera sustantiva (Bartolomé, 1987). En este sentido, el concepto audiovisual suele hacer referencia a la integración entre lo auditivo y lo visual para generar una realidad o un lenguaje. La percepción suele ser simultánea, creando, de esta manera, realidades sensoriales mediante algunos mecanismos, que según Bartolomé (1987) son: (1) el equilibrio entre el sonido y la imagen correspondiente; (2) el complemento, cada uno aporta lo que al otro le falta; (3) el soporte de las significancias sonoras y visuales persiguen el mismo propósito; y (4) la contratación de la determinación y el significado entre los dos.

La multiplicidad de sus códigos es el objetivo principal del lenguaje audiovisual, aunque existen códigos específicos, tales como los que se generan por el montaje. No obstante, también se encuentran los códigos derivados de la gestualidad, lo corpóreo y la música; formas de comunicación anteriores al lenguaje verbal y escrito. 


\subsubsection{Etapas de la realización audiovisual.}

La realización audiovisual abarca de forma general tres etapas: Preproducción, Producción y Postproducción. A continuación, la descripción de cada una de esas etapas:

\section{Preproducción.}

En esta etapa se tratan de asegurar las condiciones óptimas para la realización audiovisual. Involucra estimar el costo y tiempo de implantación del proyecto; no es necesario tener equipos especiales; y suelen involucrarse muy pocas personas. La preproducción cubre aspectos como: (1) elegir el contenido que se va a informar; (2) elegir el tratamiento audiovisual; (3) elaborar el guion literario y guion técnico; (4) evaluar los guiones; (5) redactar textos y diálogos; y (6) ubicar las locaciones.

La preproducción incluye la elaboración del material gráfico. Algunos autores indican que ese aspecto de elaboración corresponde a la postproducción. No obstante, esta varía en el tiempo y se adecúa a los requerimientos de la producción (Bartolomé, 1987). La preproducción, en general, comprende las actividades propias de preparación para llevar a cabo el rodaje, lo que implica planificar y seleccionar la idea principal que guiará el proceso (León, 2018).

\section{Producción.}

En esta etapa se incluyen los registros sonoros y de imágenes (León, 2018). Esta fase involucra una gran parte de la inversión, y el recurso humano se vuelve vital: intervienen técnicos, intérpretes, entre otros. Asimismo, se requiere de equipos para la preparación de detalles. La producción amerita un esfuerzo para coordinar con anticipación los recursos disponibles, a fin de asegurar la ejecución efectiva del proyecto (Bartolomé, 1987).

\section{Postproducción.}

Esta etapa incluye la edición del material grabado y los recursos estéticos y expresivos que se idearon para transmitir la idea inicial (León, 2018). También es necesario tomar en consideración aspectos como montaje, sonorización, rotulación, evaluación, edición de copias, entre otros. En la postproducción, el número de personas involucradas se 
reduce; sin embargo, se siguen utilizando algunos equipos. La rapidez y eficacia del producto depende de la rigurosidad en la planificación y ejecución de las etapas anteriores (Bartolomé, 1987).

\subsubsection{Avances tecnológicos dentro del mundo audiovisual}

Desde la perspectiva teórica desarrollada por Alonso (2002), la historia de la cultura audiovisual y la influencia que han tenido las nuevas tecnologías en su evolución se puede analizar desde cuatro áreas de influencia o fragmentaciones: (1) fragmentación estética, que refleja cómo algunos cambios de orden técnico integran el proceso artístico dentro del proceso de comunicación, y cómo el arte, a su vez, genera cambios de percepción visual que se impregnan en las diferentes facetas de la vida cotidiana, como la moda, el diseño e ilustración, televisión, música, cine y en casi todos los medios audiovisuales; (2) fragmentación política-social, definida por todos aquellos procesos que construyen el camino hacia la democratización de las sociedades, que están abiertas a nuevos sustentos de conocimientos y que no es posible realizar por la carencia de libertad de expresión, abriendo fronteras ante todo tipo de pensamientos, que promueven las ideas de una forma más general; (3) fragmentación económica, referida a periodos de crisis social y política que se traducen en dificultad para implementar ideas tecnológicas, debido a retardos generados por limitaciones en la inversión económica, lo que ralentiza los progresos en el mundo audiovisual; y (4) fragmentación multimedia, generadora de un proceso integrador de los medios tecnológicos y audiovisuales, que surge en respuesta a la fragmentación económica, y aprovecha las potencialidades y ventajas que el internet ha tributado a los sistemas de comunicación.

En la Figura 1.1 se grafican los principales hitos de los medios de comunicación a lo largo de la historia. Ese devenir coloca en evidencia la rapidez de los cambios experimentados por los medios de comunicación a partir de la digitalización.

Figura 1.1

Línea del tiempo de los medios de comunicación 


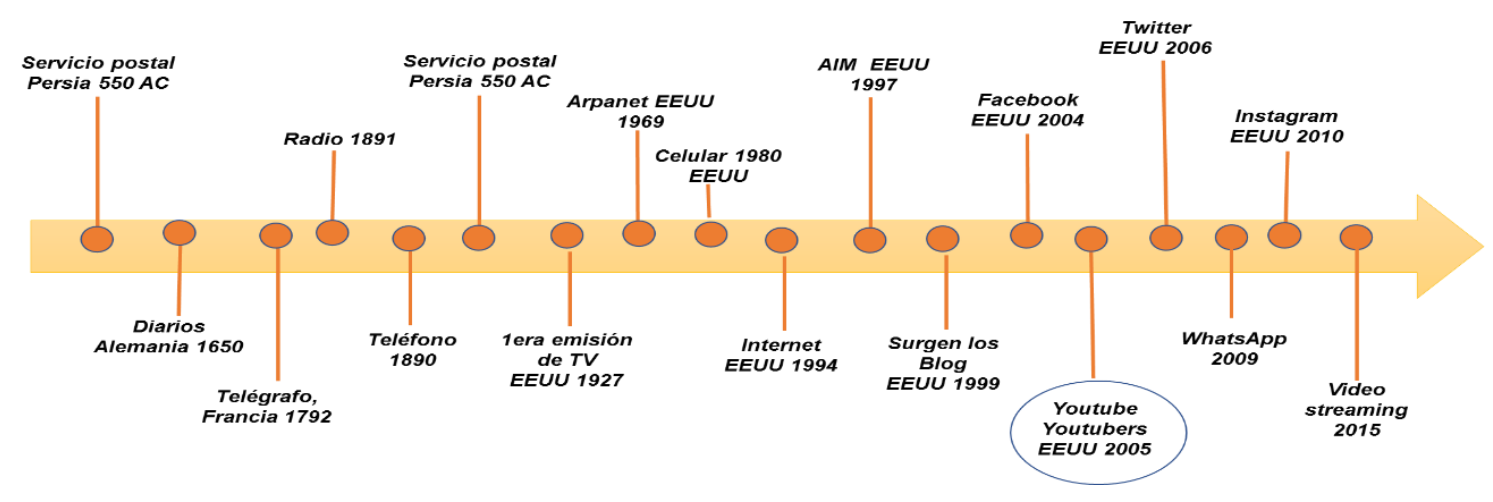

Fuente: Elaboración propia.

\subsection{La era analógica}

La era analógica es una categoría de análisis que hace referencia, básicamente, al periodo que va desde las primeras experiencias con la cámara oscura en el siglo XVI, hasta el surgimiento de las computadoras digitales y la posibilidad de mantener registros digitales. Algunos medios que se incluyen dentro de esta etapa son la cámara fotográfica clásica, el fax, teléfono, la televisión, radio, y los teléfonos móviles analógicos.

La característica esencial de las tecnologías analógicas es que se fundamentan en sistemas cuyas variables son continuas en el tiempo y pueden asumir valores infinitos (al menos en teoría). Hernández (2017) afirma que, durante las últimas décadas, el mayor impacto en el mundo de las telecomunicaciones y la radiodifusión ha sido la migración de lo analógico a lo digital. En efecto, las señales digitales que operan bajo un sistema de variables discretas y poseen un estado definido, pueden ser comprimidas, procesadas y almacenadas con tecnologías informáticas, lo cual facilita la mejora, ampliación, eficiencia, innovación y flexibilidad de los servicios de comunicación.

Desde mediados del siglo XX, la televisión se consagra como la manifestación más notoria de la era analógica y, a partir de ese momento, se producen desarrollos de los sistemas de televisión, tanto estatales como privados. La transmisión de imagen y audio en la televisión analógica se basa en pulsos electrónicos que generan ondas de radio que viajan por el aire a través de bandas VHF y UHF (frecuencia muy alta y frecuencia ultra alta), señales que luego son traducidas mediante dispositivos creados para tal fin. Este mismo sistema es aplicado a otros modos de telecomunicaciones de la era analógica, como la radio o la telefonía (Reyes, 2007). La popularización del medio y la televisión a color fueron dos hitos en su evolución, que dieron paso a su adaptación a la tecnología digital; lo que condujo a un fenómeno conocido, en su momento, como "apagón 
analógico". Esto consistió en el cese definitivo de las transmisiones televisivas mediante tecnologías analógicas.

\subsection{La era digital: emergencia de una revolución}

La llegada de una era signada por el mundo digital es catalogada como la segunda revolución industrial y, tal como se observa en la Figura 1.1 (p. 4), a diferencia de la progresividad y el tiempo lento de la era analógica, su desarrollo ha sido vertiginoso y hegemónico, lo cual se evidencia en el acelerado proceso de transformaciones, producido en menos de 40 años: el salto cualitativo en la calidad, diversidad y complejidad de los servicios desencadena la denominada sociedad de la información, el conocimiento y el riesgo. Estas transformaciones se fundamentan en la aplicación de un conjunto de tecnologías que han expandido las capacidades de comunicación humana, de un modo extraordinario e insospechado (Jódar, 2010).

En este sentido, al hablar de revolución digital, se hace referencia al conjunto de procesos de producción y comunicación que son movidos por el efecto sinérgico de las tecnologías emergentes. Las mismas, entre otros y muchos impactos, provocan la creciente pérdida de autonomía de las personas y organizaciones, en virtud de que la naturaleza de la era digital exige avanzar en el desarrollo de procesos y métodos signados por la flexibilidad, la condición cooperativa y la vocación multidisciplinaria. La comunicación experimenta profundos cambios a partir de la incidencia de las tecnologías de la informática, particularmente en lo que respecta a las formas de registro, procesamiento, almacenamiento y distribución de textos, sonidos, construcciones espaciales e imágenes fijas o en movimiento

Por ello, resulta decisivo comprender y explicar la magnitud, alcance e impacto producido por la apropiación social de las nuevas tecnologías digitales. En este contexto, la tecnología se concibe como mediación entre la ciencia y la sociedad. De esta manera, los adelantos tecnológicos provocados por la ciencia se pueden traducir en dispositivos o servicios que pueden ser comercializados. Asimismo, un medio tecnológico, para sobrevivir en esos tiempos de cambio, necesita transformarse con fines adaptativos (Jódar, 2010).

Los aportes de las tecnologías digitales al desarrollo cultural y social aplicado a la comunicación, hacen referencia a la posibilidad de producir conocimientos que 
respondan a los intereses de los usuarios. Los tecnosuburbios, por ejemplo, ofrecen mayores posibilidades de informarse y obtener trabajo, sin necesidad de que las personas se desplacen geográficamente (Alonso, 2002). Es así como la sociedad del conocimiento, como condición vital para su existencia, exige que quienes formen parte de ella estén siempre conectados e informados, y orienten su comportamiento a la inmediatez.

En este contexto, y como se observó en la Figura 1.1 (p. 4), la creación de YouTube en 2005 marca el punto en el que, podría decirse, que nace el primer youtuber, cuando los cofundadores comparten el video "Me at the Zoo". No obstante, aún no existía esta categoría de profesión ni algo similar. Al año siguiente, 2006, YouTube ya recibía 65.000 videos diarios y eran reproducidos, en promedio, 100 millones de videos al día. Aunque, no es hasta el 2009 cuando comienza a popularizarse la categoría de youtuber, y se conocen los primeros usuarios, catalogados así en España y otros países del mundo.

\subsubsection{La mediamorfosis}

Fidler (1998) hace referencia a la mediamorfosis como la tendencia permanente de adaptación y cambio que experimentan los medios. Cambios que son producidos o empujados por los adelantos tecnológicos y las emergentes demandas de la sociedad. Son indicadores de la evolución de los medios. En sentido darwiniano, la complementariedad existente entre los nuevos y viejos medios es a través de procesos de reconfiguración de usos, lenguajes y ajustes, con el fin de atender las demandas de audiencias objetivas.

La coexistencia de las diferentes tecnologías en la nueva era digital, marca la pauta de los logros, formas y modos técnicos. En este contexto, con el despliegue de los sistemas digitales, las nuevas TIC y los new media, los medios tradicionales se ven obligados a redefinirse para evitar su desaparición. Es así como, por ejemplo, la prensa, a partir del periodismo electrónico, ha logrado evolucionar en procesamiento de información, para poder ofrecer contenidos especializados e inmediatos (Alberich y Roig, 2005).

Alberich y Roig (2005) usan la expresión new old media para referirse a los nuevos medios digitales, mostrando así una evolución con respecto a los denominados mass media. La digitalización de los medios no solo es expresión de los cambios en los medios tradicionales y su adecuación a las nuevas tecnologías, sino que implica la 
reconfiguración del entorno comunicacional, que hace posible profundizar en los temas y facilitar el acceso a los contenidos bajo el manejo arbitrario de los usuarios. Significa, entonces, hacer más interactivos y especializados los procesos de la comunicación.

\subsection{El fenómeno de los "youtubers"}

\subsubsection{La plataforma YouTube}

El sitio web YouTube fue creado por Chad Hurley, Steve Chen y Jawed Karim en febrero de 2005 en California, Estados Unidos. La descripción de esta plataforma es definida como un sitio web de vídeos, que permite que millones de usuarios consigan, vean y compartan videos originales. La conceptualización de usuarios y la acción de compartir, llevan a esta plataforma a formar una red social virtual donde se pueden producir millones de interacciones, creando contenido y compartiendo información similar a otros espacios virtuales como Facebook o Twitter. En los últimos años, la plataforma de YouTube se ha expandido de modo exponencial, convirtiéndose, después del correo electrónico, en el servicio de internet con mayor cantidad de usuarios, con una cifra aproximada de 16 millones de visitas al mes (Gómez, 2014).

En otoño de 2006, Google alcanzó un contrato de compra de más de mil seiscientos millones de dólares, prueba de un compromiso estratégico con los contenidos audiovisuales. No solo por YouTube, sino por actores como Vimeo o Hulu, con una evolución diferente. En los últimos diez años, el poder de influencia de YouTube ha permitido desarrollar una generación de youtubers, para usuarios y consumidores de videos de esta plataforma.

\subsubsection{Los youtubers}

La aparición de las primeras figuras de youtubers en el mundo data del año 2009, que, progresivamente, fueron ganando seguidores e incrementando el número de visualizaciones de sus videos. De esta manera, una actividad que se inicia como un hobby, se convierte luego en una profesión, con marcada orientación a la fama.

Los youtubers son generadores de contenido en YouTube; son personas que graban videos sobre sí mismos o un contexto, y administran el contenido en sus canales 
de YouTube. Es posible encontrar gran variedad de material, como asuntos personales, video juegos, guías o tutoriales, miniseries, música o humor. La etiqueta de youtuber se les asigna a aquellos que han tenido éxito y popularidad en la distribución de videos a través de esta plataforma, independientemente de que el criterio de lo que es exitoso varía por el lugar, momento o sector (Gómez, 2014).

El contenido que generan los youtubers se percibe como el producto de un proceso que inicia con el registro de una información. Con frecuencia contempla la elaboración de un guion, edición de un video, producción (si se precisa) y, ocasionalmente, la interpretación de determinados contenidos.

Un elemento identificador de este proceso de creación audiovisual en YouTube es la periodicidad, esta rapidez e interconexión permanente y directa con una audiencia expectante. La noción de calidad de la producción audiovisual de los youtubers es relativa y parece más asociada a la interacción de los usuarios por su pertenencia a un grupo social que comparte valores y preferencias comunes. Tal inclinación no significa que se soslayen aspectos como el método, la técnica y el contenido con que son elaborados los videos a la hora de evaluar lo que hacen los youtubers.

El éxito de los youtubers tiende a valorarse a partir de los niveles de difusión e ingresos económicos que logran alcanzar, así como la comparación entre ellos. Muchas personas mueven grandes masas de personas, fenómeno que es posible comparar con el de las estrellas de rock. En este fenómeno, hay muchas cosas nuevas y otras que están asociadas con la creatividad y los formatos convencionales (Berzosa, 2017).

\subsubsection{Los youtubers desde una perspectiva comunicacional}

YouTube se convirtió en un fenómeno cultural y mediático, permitiendo el consumo de los recursos que invitan a compartir; así como a la incorporación de videos en otros sitios. Según Martín (1998), se trata de un espacio que facilita al usuario común la posibilidad de desarrollar sus talentos para la producción mediática. Se estima que YouTube cuenta en la actualidad con un millón de usuarios y ocupa el 95\% de los contenidos disponibles en la web.

Las cifras dan cuenta de la dimensión y la relevancia que el sitio adquiere dentro del actual contexto y permite tomar a YouTube, no solo como plataforma mediática, sino 
como un fenómeno comunicacional establecido por medio de él, y en el que se inserta como un reflejo del escenario de mediatización de la sociedad. En este sentido, según Martín (1998), la idea de mediatización surge para dar cuenta del modo cómo se conectan la cultura y los medios, como consecuencia de la participación de los medios en las relaciones de los seres humanos. Por su parte, según Braga (2006) las sociedades mediáticas serían aquellas en las que los procesos sociales y culturales, en todas las esferas, pasan por los medios y tienen en ellas un factor, si no determinante, al menos condicionante, de forma que no hay una distinción clara entre la esfera de los medios y las demás instancias de la sociedad.

Bajo esta misma visión teórica, Braga (2006) toma por base la idea de mediación para elaborar su concepto de sistema social de respuesta; pensar en la mediatización significa pensar en una dinámica comunicacional circular, en el que la transmisión de información no se limita a los procedimientos de emisión y recepción de mensajes considerados por las teorías de la comunicación tradicionales, sino que al tener las condiciones técnicas y culturales de consumir contenidos, así como de producir y difundir informaciones, el público se vuelve capaz de interactuar con los productos mediáticos a través de respuestas que considera productivas, configurando una tercera instancia comunicacional: la circulación.

Para el autor, los dispositivos sociales que surgen, a partir del escenario de mediación, orientados a la producción de contenidos que sirven de respuesta social a los productos mediáticos, pueden interpretarse como los modos de organización de la sociedad para interactuar con los medios, poniendo en circulación temas que son posibles de perfeccionar y reajustar, de acuerdo con las necesidades comunicacionales de grupos específicos.

\subsubsection{Los youtubers como modalidad emergente de producción audiovisual}

Los proveedores de contenido y los usuarios aceptan compartir la gestión, el tratamiento y los códigos de consumo de contenidos. Es importante destacar que el internet, con frecuencia, proporciona acceso gratuito a los productos, y el enfoque de la relación son básicamente diarios, individuales y, a menudo, portátiles. No hay programaciones establecidas o limitaciones que no sean considerados con anterioridad. Mostrar el contenido que YouTube ofrece a los usuarios es una forma de consumo personalizable, 
además de ofertas gratuitas, permite que sus suscripciones ilimitadas aparezcan en sus pantallas.

Los nuevos videos se reciben a través de notificaciones sobre el inicio y la información en la barra de opciones de correo y el canal. Por lo tanto, conecta a los fabricantes y usuarios de la plataforma para diferentes servicios que brindan rutas de acceso múltiples y de fáciles condiciones, adecuadas a los nuevos ritmos y velocidades de los usuarios contemporáneos. Estas condiciones emergentes de producción permitieron multiplicar su propia producción con un alto nivel de personalización. (López, 2016).

Los canales de YouTube se encuentran organizados como una especie de galerías, en las cuales las creaciones audiovisuales son estructuradas cronológicamente, y pueden ser de productores individuales, colectivos o de contratistas de consumo cultural. Dentro de esta interfaz, son diversas las capacidades expresivas, pues los autores interactúan constantemente con los usuarios, lo que permite que estos evalúen su producción, se expresen mediante comentarios y likes, y que compartan el contenido, incluso que carguen sus propios videos en la misma plataforma.

Por tanto, YouTube es una estructura de red abierta a la participación, en la cual juegan un papel relevante la dimensión estética, la imagen personal y la construcción de sentidos a partir del contenido. Dicha estructura, a su vez, facilita la medición de viralización de los videos en internet, y cómo las tecnologías interactivas se conectan con la mediática tradicional (López, 2016).

Las taxonomías que hacen referencia a la estructura del contenido y a las principales modalidades de las personas de habla hispana, describen un fenómeno muy reciente que tiene una gran cantidad de oportunidades para la diversificación de la temática y la complejidad narrativa. Los productores exitosos de YouTube, que gozan de muchos seguidores y reciben muchas visitas, vienen impulsando la idea de desarrollar, junto con sus usuarios, una producción exponencial de contenidos, que abre las puertas a la creatividad existente en toda su audiencia.

En este contexto y circunstancias, las empresas enfocadas en la gestión y desarrollo de contenidos audiovisuales tienen la oportunidad de expandir el mercado de contenidos de modo exponencial, tomando en consideración la participación y aporte de 
una considerable diversidad de usuarios de las nuevas generaciones (denominados por algunos como multipantallas) (López, 2016).

\subsubsection{Comparación entre la producción audiovisual tradicional y la producción audiovisual emergente de los youtubers}

Establecer puntos de comparación entre ambas modalidades de producción audiovisual no es una tarea sencilla, tomando en cuenta que la experiencia de creación de productos audiovisuales en YouTube está estrechamente vinculada con la evolución de la producción audiovisual en sus componentes técnicos, narrativos, de contenidos, de proceso o difusión. Sin embargo, es posible realizar una aproximación a consideraciones de contraste entre ambas formas de producción audiovisual, a saber:

- La lógica de creación/difusión de YouTube convierte a los tradicionales consumidores en productores y difusores autónomos de contenidos audiovisuales. $\mathrm{Al}$ respecto, Bertossi dice: "Hay un cambio en el consumidor, que abandona una posición donde recibe contenidos producidos por un pequeño grupo para pasar a generar, filtrar y distribuir contenidos en un rol más activo" (Como se citó en Quintero, 2017, p. 78). De ello se desprende la creciente "desintermediación entre el autor/productora/distribuidora y el consumidor final" de los productos audiovisuales. Los youtubers asumen todos los roles (en equipos de youtubers, a cada integrante le corresponde asumir varios roles), y ello se traduce en una comunicación de muchos hacia muchos, sin mediación de los medios y actores tradicionales. De esta manera, existen usuarios que producen de forma independiente, alejados de las industrias culturales, y generan formatos novedosos, mediante soluciones ingeniosas y recursos propios. Por otro lado, se percibe a las industrias de producción audiovisual, en sus disímiles procesos de adaptación a los cambios tecnológicos, con nuevos y viejos esquemas (Pérez y Gómez, 2013, p. 5).

- Formas de interacción: en torno a la interacción directa e inmediata con el público, el éxito de los youtubers y de sus productos se encuentra determinado por la reacción del público, y esta es medida con precisión a través de la retroalimentación, caracterizada por la inmediatez que se expresa en los likes, dislikes, comentarios, suscripciones, compartir, calificar y muchos otros 
mecanismos de los que dispone YouTube para la interacción. Existe, inclusive, la posibilidad de interacción en tiempo real de los usuarios a través de las transmisiones en vivo. En esta plataforma se encuentran mecanismos de difusión directos, inmediatos y con ninguna o poca presencia de mediadores, como sí ocurre en las producciones audiovisuales, en las que es posible incorporar líneas telefónicas para promover la participación del público, pero las intervenciones siempre están filtradas y mediadas por los productores, que deben ajustarse a normas más estrictas. De esta manera, los youtubers se conectan con otras redes expandiendo la circulación de sus contenidos, al tiempo que avanzan en la integración de comunidades y el desarrollo de trabajos colaborativos. De la misma forma, en la producción tradicional, se ha logrado una mejor integración a las redes sociales y, en medio de programas, se promueven encuestas, debates por medio de algún hashtag o comentarios directos a la cuenta del medio o programa, lo que quiere decir que el medio tradicional busca emular la sensación de interacción inmediata de medios como YouTube.

- Promoción y viralización: la producción audiovisual emergente de los youtubers está definida por tres características básicas en términos de promoción y viralización: (a) continuidad, pues los youtubers no se definen por una creación única o que llegue a su fin, sino por la permanencia del canal, la regularidad en la publicación de sus creaciones y la satisfacción de la demanda de los usuarios; (b) flujo de información, lo que alude a la característica de circulación y viralización de las creaciones a través de múltiples plataformas (como otras redes sociales), que multiplica las posibilidades de acceso al producto; y (c) popularidad, que se produce desde la construcción de una identidad y el conocimiento de los contenidos que esperan los usuarios, impulsando de ese modo un proceso de identificación y fidelización por parte de la audiencia, que participa activamente en la viralización del contenido. Esto se ve facilitado por lo asincrónico que son los contenidos en YouTube, a diferencia de los medios tradicionales, donde estos son programados en horarios específicos, de modo que, más allá de lograr altos niveles de rating, no es posible obtener efectos similares a los de la viralización, pues la información con potencial viral tardaría más tiempo en transmitirse entre la audiencia objetivo, que lo que dura el programa. De hecho, es más probable que el contenido se haga viral posteriormente, como producto digital, gracias a que el medio o algún espontáneo, lo suban a YouTube u otra red social. 
- Los contenidos: aunque los contenidos de ambos tipos de producción audiovisual se encuentran vinculados de la misma manera con las vivencias humanas, podría decirse que la producción audiovisual de los youtubers se define naturalmente por su irreverencia, desarrollando, en ocasiones, contenidos que han sido poco tocados o abordados de formas más comedidas. A este respecto, Londoño y Castañeda (2014) citan a Mier (2009), quien afirma que YouTube es un espacio abierto a posturas y temas poco comunes, libre de una programación preestablecida, pues responde a las demandas, gustos y tendencias de los usuarios y no a una línea editorial. Adicionalmente, pueden mencionarse algunos formatos novedosos de los youtubers (Pérez y Gómez, 2013), en cuanto a contenido, como los siguientes: remix (adaptación o reelaboración del producto audiovisual a partir de imágenes y sonidos de otros autores), fandom (actividad creativa de un fan que toma como inspiración la obra de otro autor), lip-dub (video musical en el que varias personas doblan, bailan y realizan otras acciones al ritmo de una canción, obra de otro autor), habilidades artísticas (cualidades de un usuario: interpretación musical de un instrumento, canción o coreografía, o habilidad física extraordinaria), vlog (video-blog testimonial, adaptación directa del blog personal textual y del podcast sonoro a las posibilidades del audiovisual), webisodes (un formato a medio camino entre el cortometraje de ficción -por su duración, estructura y carácter de ficción- y la serie de televisión -por la continuidad entre las diferentes unidades narrativas que componen la serie), entre otros. Los medios tradicionales pueden intentar emular algunos de estos formatos, pero siempre resulta menos orgánico, porque no fueron diseñados para la televisión. De la misma forma, los youtubers pueden intentar recrear formatos más complejos en la plataforma, pero resulta poco orgánico y no logra el mismo efecto que en los medios tradicionales.

- Calidad de la producción (nivel de profesionalidad): YouTube se distingue porque coloca a los usuarios en una relación de horizontalidad. Es por ello que es posible encontrar en YouTube y en los youtubers la combinación de trabajos audiovisuales de todos los niveles: profesional, semiprofesional o amateur (Pérez y Gómez, 2013). Asimismo, debe considerarse, además, que usuarios no profesionales pueden generar piezas con alto nivel técnico, o usuarios profesionales generan, en ocasiones, productos con intencionada apariencia 
amateur. Aquí que es importante destacar que la calidad de la producción se asume, entonces, como una categoría compleja, que no está únicamente vinculada al grado de profesionalización, presupuesto y tecnologías disponibles. En este sentido, Londoño y Castañeda (2014) destaca la presencia de youtubers que, a pesar de carecer de una carrera en el mundo de los medios tradicionales o no contar con una formación adecuada en materia audiovisual, logran posicionarse debido su papel destacado en las redes sociales y, gracias al apoyo de los usuarios, comparten sus creaciones. Esta profesionalización progresiva no es permitida en los medios tradicionales, quienes contratan solo profesionales experimentados, que trabajan en equipos, muchas veces sobre bases de manuales de estilo que no les permiten demasiada libertad creativa.

- Otras consideraciones inherentes al proceso de producción audiovisual:

- El tiempo es una variable determinante en Internet, pues se exige mayor brevedad y consistencia en las producciones audiovisuales (menos de 4 minutos de video es lo sugerido, comúnmente).

- El proceso de producción audiovisual de los youtubers sigue las mismas etapas de preproducción, producción y postproducción, pero por lo general, estos se desarrollan de forma más simplificada.

- Es común que el producto se presente al público tal como fue pensado y luego, a partir de sus reacciones, este se va trasformando.

- Los productores audiovisuales de YouTube siguen, en muchos aspectos, a la producción audiovisual tradicional, pero es más usual que sigan a otros youtubers de éxito.

- La producción audiovisual tradicional pasa, regularmente, por una serie de filtros y estudios de prefactibilidad; mientras que la de los youtubers está más abierta a la experimentación, al ensayo y error, al uso de nuevos formatos y métodos, así como al abordaje de nuevos contenidos y narrativas. Pérez y Gómez (2013) afirman en torno a ello que el youtuber no se encuentra sometido, directamente, a las condiciones impuestas por la industria audiovisual, lo que deviene en el ejercicio libre de su creatividad e innovación, en la generación de nuevos formatos y la experimentación con el lenguaje, siendo sus únicas limitaciones: presupuesto, plataforma tecnológica e ingenio. 
- Los youtubers han adoptado y adaptado las técnicas propias de la tradición audiovisual; no obstante, Quintero (2017) destaca algunas particularidades observadas en los canales de YouTube, a saber: (1) cuando el peso expresivo se proyecta sobre la imagen visual, se asume el plano general como escala de planimetría dominante; (2) cuando el texto hablado toma el protagonismo del peso expresivo, la escala de planimetría se mueve entre el plano medio y el primer plano; (3) el zoom in es de uso muy regular y opera como como hipérbole de una expresión gestual somática; (4) mientras el primer plano y el plano medio son, generalmente, planos fijos, el plano general casi siempre es móvil; (5) el uso del texto hablado rápido es inversamente proporcional al uso de la auto-referencialidad, de modo que se cumple eficientemente el ejercicio de la función descriptiva del narrador extradiegético; (6) cuando el narrador es expositivo, su discurso es veloz; no obstante, dicho narrador regula la velocidad del mismo cuando se dirige de manera directa al público.

- Lógica comercial: la creación de YouTube y su popularización dio lugar a la llegada de nuevas lógicas comerciales cuyo rasgo distintivo más apreciable es el establecimiento de relaciones económicas directas, sin los tradicionales intermediarios y múltiples actores involucrados desde el financiamiento, producción, promoción y divulgación de la realización audiovisual. El usuario o youtuber que inicia un proceso de monetización lo hace con Google Inc., o mediante un canje directo con anunciantes específicos. Recientemente, se han popularizado las empresas de asesoramiento y profesionalización para los creadores de contenido, que facilitan ese proceso de monetización. En este entorno digital, por ende, predominan las producciones de bajo presupuesto. 


\section{CAPÍTULO II: METODOLOGÍA}

\subsection{Pregunta principal de investigación}

¿De qué manera los youtubers constituyen una modalidad emergente de producción audiovisual en el Perú?

\subsection{Preguntas específicas de investigación}

- ¿Cuáles son las características identitarias de los medios de producción audiovisual en la era digital y en el contexto peruano?

- ¿Cómo se caracteriza el fenómeno de los youtubers desde una perspectiva comunicacional?

- ¿De qué manera influyen los youtubers como modalidad emergente de producción audiovisual en el Perú?

\subsection{Objetivo general}

Analizar a los youtubers como modalidad emergente de producción audiovisual en el Perú.

\subsection{Objetivos específicos}

- Describir las características identitarias de los medios de producción audiovisual en la era digital y en el contexto peruano.

- Describir el fenómeno de los youtubers desde una perspectiva comunicacional.

- Determinar la influencia de los youtubers como modalidad emergente de producción audiovisual en el Perú. 


\subsection{Descripción de la investigación}

Para Hernández, Fernández y Baptista (2014), la investigación comprende un conjunto de procesos empíricos, sistemáticos y críticos que se aplican para describir, explicar y predecir el comportamiento de un fenómeno, realidad o problema. La misma, generalmente, incluye el enfoque, métodos, técnicas e instrumentos, mediante los cuales se desarrolla el proceso de investigación.

Así, se trató de una búsqueda de naturaleza cualitativa, que implicó el siguiente procedimiento metodológico:

- Identificación de los informantes clave mediante el muestreo intencional.

- Aplicación de las entrevistas a los informantes clave, mediante una entrevista semiestructurada.

- Procesamiento del contenido de las entrevistas, siguiendo las etapas de codificación abierta y axial sugeridas por Strauss y Corbin (2002).

- Resumen de los procesos de codificación abierta y axial en cuadros comparativos, con fines interpretativos.

\subsection{Muestra}

Mediante un muestro intencional, se seleccionaron los siguientes informantes clave: un productor audiovisual, tres youtubers y un analista de medios digitales. Los mismos cumplieron con dos criterios previamente establecidos: conocimiento sobre el tema tratado y disposición a brindar información.

\subsection{Técnica e instrumento de recolección de datos}

Para la recolección los datos cualitativos se utilizó una entrevista cualitativa semiestructurada aplicada a un productor audiovisual de TV (César Arana), un profesorespecialista en producción audiovisual (Profesor Subauste) y tres youtubers, a saber, El Vicho $^{1}$ (booktuber, literatura), Karina Arancibia ${ }^{2}$ (repostería, emprendimiento) y Daniela $\operatorname{Acosta}^{3}$ (fashion vlogger). A tal efecto, se desarrolló una guía de entrevista (Anexo 1)

\footnotetext{
${ }^{1}$ https://bit.ly/2RX4hp6

${ }^{2}$ https://bit.ly/2uFpVWM

${ }^{3}$ https://bit.ly/318zdXE
} 
que versa sobre los aspectos comparativos entre las producciones audiovisuales tradicionales, emergentes y de youtubers, concretamente en lo referente a contenidos, técnicas audiovisuales y formas de interacción, promoción y viralización.

\subsection{Técnica de análisis}

Para los datos cualitativos, se realizó un análisis de forma sistemática a partir de las etapas de codificación abierta y codificación axial, definidos por Strauss y Corbin (2002) en los siguientes términos:

- “Codificación abierta: el proceso analítico por medio del cual se identifican los conceptos y se descubren en los datos sus propiedades y dimensiones" (p. 110).

- "Codificación axial: proceso de relacionar las categorías a sus subcategorías, denominado "axial" porque la codificación ocurre alrededor del eje de una categoría, y enlaza las categorías en cuanto a sus propiedades y dimensiones" ( $p$. 134). 


\section{CAPÍTULO III: RESULTADOS}

A continuación, se presentan los resultados de la investigación acerca de la figura del youtuber en la producción audiovisual. Estos se generaron a partir de entrevistas a tres tipos de informantes clave: youtubers, productores audiovisuales y analistas de medios digitales. Los resultados fueron organizados para responder las preguntas que orientaron la realización del presente estudio.

\section{1. ¿Cuáles son las características de los medios de producción audiovisual en la era digital y en el contexto peruano?}

Para responder a esta interrogante, se presentan las siguientes tablas de análisis. La Tabla 3.1 se enfoca en la comparación de las características que presenta el medio digital, objeto de la presente investigación (YouTube) y los medios tradicionales. La Tabla 3.2 (p. 22) se enfoca en las características que presentan los medios digitales que los hacen hegemónicos en el espectro comunicacional del mundo en general, y de Perú en particular. Finalmente, la Tabla 3.3 (p. 23) presenta un cuadro comparativo sobre los valores de producción de los canales de YouTube de los tres youtubers entrevistados.

Tabla 3.1

Características de YouTube en comparación con los medios tradicionales de comunicación

\begin{tabular}{|l|l|l|}
\hline \multicolumn{1}{|c|}{ Aspectos } & \multicolumn{1}{|c|}{ Características de YouTube } & \multicolumn{1}{c|}{ Medios tradicionales } \\
\hline Información & $\begin{array}{l}\text { Diversa, segmentada y ajustada a los } \\
\text { requerimientos de los usuarios. }\end{array}$ & Difundida para todos los públicos. \\
\hline $\begin{array}{l}\text { Participación de los } \\
\text { usuarios }\end{array}$ & $\begin{array}{l}\text { Productores, electores y receptores } \\
\text { de contenidos. }\end{array}$ & Receptor de contenidos. \\
\hline $\begin{array}{l}\text { Posibilidades de } \\
\text { crecimiento }\end{array}$ & En plena expansión. & $\begin{array}{l}\text { En proceso de adaptación a la era } \\
\text { digital. }\end{array}$ \\
\hline Interactividad & Total. & Limitada. \\
\hline $\begin{array}{l}\text { Complementariedad con } \\
\text { otros medios }\end{array}$ & Comunidad multiplataforma. & $\begin{array}{l}\text { En proceso de adaptación a la era } \\
\text { digital. }\end{array}$ \\
\hline
\end{tabular}

Fuente: Entrevistas a youtubers, productores audiovisuales y analistas de medios digitales. 
En la Tabla 3.1 (p. 20) se presentan las características de YouTube como medio de comunicación digital en comparación con los medios tradicionales. La primera característica analizada se refiere a la información. Allí se establece que la información ofrecida por YouTube es "Diversa, segmentada y ajustada a los requerimientos de los usuarios". Diversa, porque los usuarios disponen de una gigantesca cantidad de información referida a muchos ámbitos temáticos. Segmentada y ajustada a requerimientos, debido a que los usuarios en YouTube pueden localizar información para dar respuesta a sus intereses particulares de búsqueda. Estas características difieren de los medios tradicionales, donde el usuario carece de la posibilidad de adecuar la información que recibe a sus necesidades personales.

La otra característica que ofrece YouTube, según la Tabla previamente mencionada, es que los usuarios tienen la oportunidad de participar como receptores (reciben), electores (eligen) y productores (crean) de contenidos, características que facilitan el acondicionamiento del medio a las necesidades particulares e intereses de los usuarios, al tiempo que ofrece infinitas posibilidades para la creación del trabajo asociativo entre quienes participan en esta red social. Ese amplio abanico de oportunidades de participación que ofrece YouTube, contrasta con los medios tradicionales, donde los usuarios juegan un rol pasivo y generalmente solo actúan como receptores de información.

La Tabla 3.1 (p. 20) también expresa el consenso existente entre todos los entrevistados en cuanto a que YouTube, así como todos los medios digitales, se encuentra desde hace varias décadas en proceso de expansión, lo cual ha sido favorecido el contexto cultural y tecnológico que ofrece la denominada sociedad de la información o el conocimiento. Mientras tanto, los medios tradicionales, para sobrevivir a esta era de cambios, vienen manteniendo un comportamiento adaptativo que, básicamente, consiste en la migración hacia plataformas digitales.

La interactividad entre productores y usuarios de contenidos, según la Tabla 3.1 (p. 20), es otra de las características que ofrece YouTube como medio de comunicación digital. La dinámica de estos medios, a partir de esa interactividad, conlleva a la conformación de pequeñas, medianas y grandes comunidades, lo mismo que las redes, que incrementan los niveles de interactividad. En los medios tradicionales, las posibilidades de interacción son limitadas. 
Finalmente, con referencia a YouTube, en la Tabla 3.1 (p. 20) se observa que otra de sus características es la complementariedad entre los medios digitales y tradicionales a través de las multiplataformas. Este proceso tiene su asiento en el hecho de que las TIC, y la sociedad del conocimiento, en general, se fundamentan en una visión sistémica, compleja y de redes. Particularmente, los medios tradicionales vienen insertándose progresivamente a la dinámica de la mediática digital.

Tabla 3.2.

Hegemonía de medios de comunicación digital

\begin{tabular}{|l|l|l|}
\hline \multicolumn{1}{|c|}{ Aspecto } & \multicolumn{1}{|c|}{ Medios digitales } & \multicolumn{1}{c|}{ Medios tradicionales } \\
\hline Consumo del medio & En fase de crecimiento, elevada. & En decrecimiento, baja. \\
\hline Participación de los usuarios & $\begin{array}{l}\text { Receptores, electores y } \\
\text { productores de contenidos. }\end{array}$ & $\begin{array}{l}\text { El medio determina los } \\
\text { contenidos. }\end{array}$ \\
\hline Cadena medio- empresas & En fase de crecimiento. & En decrecimiento. \\
\hline Proyección futura & Liderazgo de los millenials. & $\begin{array}{l}\text { En proceso adaptativo a la era } \\
\text { digital. }\end{array}$ \\
\hline $\begin{array}{l}\text { Confiabilidad de la } \\
\text { información }\end{array}$ & Baja. & Elevada. \\
\hline Economía de medios & Bajos costos. & Insostenibilidad de los costos. \\
\hline
\end{tabular}

Fuente: Elaboración propia.

En otro esfuerzo por ofrecer una panorámica de los medios digitales, la Tabla 3.2 identifica una serie de características que explican la creciente hegemonía que, en la actualidad y hacia el futuro, tienen los medios de comunicación digital. Las tendencias muestran un elevado y creciente consumo de los medios digitales en contraste con el decrecimiento de los medios tradicionales. Asimismo, las amplias oportunidades de participación que ofrecen estos medios, hacen prever en el futuro inmediato el compromiso y la expansión de estos medios en la población del mundo en general y en Perú en particular.

De igual modo, los entrevistados coinciden en que los medios de comunicación digital cada vez se articulan más con los sectores empresariales, interesados en anunciar sus productos, relacionar a sus empresas y formar a los trabajadores a través de estos medios. Articulación que es fundamental para la sostenibilidad económica de los medios digitales. 
El liderazgo de los millenials es un fenómeno cultural que asegura y consolida la hegemonía de los medios de comunicación digital. Esta generación ya viene asumiendo, a partir de sus vínculos con la tecnología digital, la conducción de la mayoría de los espacios de la vida cotidiana de las sociedades actuales.

Uno de los aspectos negativos de los medios digitales, que emergieron en el desarrollo de las entrevistas, es mostrado en la Tabla 3.2 (p. 22) que consiste en el explícito reconocimiento de la baja confianza existente en mucha de la información que circula en los medios digitales. De esta situación, se abren posibilidades a los medios de comunicación tradicionales en el rol de referentes, para el cotejo de las informaciones publicadas por los medios digitales.

Finalmente, en cuanto a los factores que determinan la hegemonía presente y futura de los medios de comunicación digital, según muestra la Tabla 3.2 (p. 22), se identifican los bajos costos implicados en los medios digitales, que contrastan con los elevados presupuestos que demandan los medios tradicionales. A continuación, se presenta la Tabla 3.3, que describe los valores de producción de los youtubers entrevistados.

Tabla 3.3.

Valores de producción de los youtubers entrevistados

\begin{tabular}{|l|l|l|l|}
\hline & \multicolumn{1}{|c|}{ El Vicho } & \multicolumn{1}{c|}{ Daniela Acosta } & \multicolumn{1}{c|}{ Karina Arancibia } \\
\hline $\begin{array}{l}\text { Contenido de } \\
\text { producción }\end{array}$ & $\begin{array}{l}\text { - Booktuber. } \\
\text { - Literatura. }\end{array}$ & - Fashion Vlogger. & $\begin{array}{l}\text { - Repostería. } \\
\text { - Emprendimiento. }\end{array}$ \\
\hline Cámara usada & Canon Rebel T5i. & Sony Alpha A5100. & Canon Rebel T4i. \\
\hline Puntuación & $\mathbf{4}$ & 60 & 47 \\
\hline $\begin{array}{l}\text { Equipo de } \\
\text { iluminación }\end{array}$ & 53 & $\begin{array}{l}\text {-Soft box Godox. } \\
\text { - Ring Light. }\end{array}$ & No posee. \\
\hline $\begin{array}{l}\text { Equipo de audio } \\
\text { Programas de edición } \\
\text { utilizados }\end{array}$ & $\begin{array}{l}\text { Micrófono Saramonic } \\
\text { Shotgun. }\end{array}$ & $\begin{array}{l}\text { - Micrófono pechero. } \\
\text { - iPhone XR. }\end{array}$ & Micrófono externo. \\
\hline
\end{tabular}

(continúa)

\footnotetext{
${ }^{4}$ SnapSort (2019a; 2019b)
} 
(continuación)

\begin{tabular}{|c|c|c|c|}
\hline Recursos de terceros & $\begin{array}{l}\text { - Banco de música de } \\
\text { YouTube. } \\
\text { - Pexels. } \\
\text { - Google Images. }\end{array}$ & $\begin{array}{l}\text { - Banco de música de } \\
\text { YouTube. }\end{array}$ & $\begin{array}{l}\text { - Banco de música de } \\
\text { YouTube. } \\
\text { - Imágenes de stock. }\end{array}$ \\
\hline Equipo humano & Trabaja solo. & $\begin{array}{l}\text { Cuenta con editor de } \\
\text { videos y fotógrafo. }\end{array}$ & $\begin{array}{l}\text { Cuenta con editor de } \\
\text { video. }\end{array}$ \\
\hline Suscriptores $^{5}$ & $23.2 \mathrm{~K}$ & $94.2 \mathrm{~K}$ & $6.61 \mathrm{~K}$ \\
\hline Total de vistas ${ }^{5}$ & $1.34 \mathrm{M}$ & $7.4 \mathrm{M}$ & $181.85 \mathrm{~K}$ \\
\hline Cantidad de videos ${ }^{5}$ & 531 & 169 & 29 \\
\hline $\begin{array}{l}\text { Posición ocupada en } \\
\text { Perú / Mundo }\end{array}$ & $2.613 / 543.786$ & $909 / 193.596$ & $5.338 / 1.174 .115$ \\
\hline $\begin{array}{l}\text { Ganancias / } \\
\text { Motivación }\end{array}$ & $\begin{array}{l}\text { No comercial. } \\
\text { Compartir contenido. }\end{array}$ & $\begin{array}{l}\text { Comercial. Aspira que } \\
\text { sea fuente principal de } \\
\text { ingresos. }\end{array}$ & $\begin{array}{l}\text { Comercial. Espera que } \\
\text { el canal sea una } \\
\text { plataforma para su } \\
\text { negocio principal } \\
\text { (pastelería). }\end{array}$ \\
\hline Fases de producción & $\begin{array}{l}\text { - Escribe guiones } \\
\text { informales } \\
\text { (manuscritos). } \\
\text { - Graba de } 1 \text { a } 3 \\
\text { guiones en un mismo } \\
\text { día (con cambio de } \\
\text { vestuario incluido). } \\
\text { - Edita el material en } \\
\text { cola, paulatinamente, } \\
\text { en su tiempo libre. } \\
\text { - Programa la } \\
\text { publicación en } \\
\text { YouTube y, durante la } \\
\text { subida del video, diseña } \\
\text { banners y define los } \\
\text { elementos para el SEO. }\end{array}$ & $\begin{array}{l}\text { - No escribe guiones. } \\
\text { - Realiza la gestión con } \\
\text { las marcas anunciantes } \\
\text { para la preparación del } \\
\text { video. } \\
\text { - Graba y, sobre la base } \\
\text { de dicho trabajo, } \\
\text { redacta una pauta de } \\
\text { postproducción. } \\
\text { - La edición es } \\
\text { realizada por un tercero } \\
\text { contratado. } \\
\text { - La fotografía también } \\
\text { es realizada por un } \\
\text { tercero contratado. }\end{array}$ & $\begin{array}{l}\text { - No escribe guiones. El } \\
\text { hilo conductor es el } \\
\text { paso a paso de la receta } \\
\text { a realizar, que sí es } \\
\text { preparada. } \\
\text { - Prepara el set, los } \\
\text { ingredientes y } \\
\text { utensilios de cocina } \\
\text { requeridos, se maquilla } \\
\text { y peina, todo por cuenta } \\
\text { propia. } \\
\text { - Graba en fechas } \\
\text { definidas (suele tomar } 6 \\
\text { horas en promedio). } \\
\text { - La edición se realiza } \\
\text { un día diferente (toma } \\
\text { al menos } 10 \text { horas). } \\
\text { - El material se publica } \\
\text { martes y jueves. }\end{array}$ \\
\hline
\end{tabular}

(continúa)

\footnotetext{
${ }^{5}$ NoxInfluencers (2020a; 2020b; 2020c).
} 


\begin{tabular}{|c|c|c|c|}
\hline Métricas & $\begin{array}{l}\text { - En el último año ha } \\
\text { publicado un video } \\
\text { semanal en promedio, } \\
\text { se inició el } 21 \text { de marzo } \\
\text { del } 2014 . \\
\text { - Trabaja solo y a veces } \\
\text { en compañía de un } \\
\text { conocido, pero la } \\
\text { mayoría de sus trabajos } \\
\text { son personales. } \\
\text { - Cuenta con } 23.200 \\
\text { suscriptores y } 531 \\
\text { vídeos. } \\
\text { - Su canal cuenta con } \\
\text { 1.343.226 } \\
\text { visualizaciones en total. } \\
\text { - El vídeo con más } \\
\text { vistas tiene } 214.799 \\
\text { visualizaciones, y fue } \\
\text { subido hace un año. } \\
\text { (Que NO hacer en Perú } \\
1 \text { japonés en Perú) con } \\
19462 \text { likes y } 6987 \\
\text { comentarios. }\end{array}$ & $\begin{array}{l}\text { - En el último año ha } \\
\text { publicado un video } \\
\text { mensual en promedio, } \\
\text { se abrió el canal el } 14 \\
\text { de agosto del } 2010 . \\
\text { - Su contenido lo } \\
\text { trabaja con otras } \\
\text { personas, que son las } \\
\text { encargadas de grabar y } \\
\text { editar. } \\
\text { - Cuenta con } 94.200 \\
\text { suscriptores y } 169 \\
\text { vídeos. } \\
\text { - Su canal cuenta con } \\
7.404 .576 \\
\text { visualizaciones en total. } \\
\text { - El vídeo con más } \\
\text { vistas tiene } 325.999 \\
\text { visualizaciones y fue } \\
\text { subido hace tres años. } \\
\text { (GAMARRA: Dónde y } \\
\text { Cómo Comprar / Todo } \\
\text { sobre Gamarra) con } \\
7620 \text { likes y } 624 \\
\text { comentarios. }\end{array}$ & $\begin{array}{l}\text { - En el último año ha } \\
\text { publicado un video } \\
\text { mensual en promedio, } \\
\text { se inició el } 31 \text { de julio } \\
\text { de } 2018 . \\
\text { - Su contenido lo } \\
\text { trabaja ella sola y las } \\
\text { grabaciones son, en su } \\
\text { mayoría ella sola. } \\
\text { Algunas veces (pocas), } \\
\text { con ayuda. } \\
\text { - Cuenta con } 6630 \\
\text { suscriptores y } 29 \\
\text { vídeos. } \\
\text { - Su canal cuenta con } \\
182.462 \text { visualizaciones } \\
\text { en total. } \\
\text { - El vídeo con más } \\
\text { vistas tiene } 111.950 \\
\text { visualizaciones y fue } \\
\text { subido hace } 9 \text { meses. } \\
\text { (TORTA HÚMEDA } \\
\text { DE CHOCOLATE: } \\
\text { Receta y secretos) con } \\
3155 \text { likes y } 153 \\
\text { comentarios. }\end{array}$ \\
\hline
\end{tabular}

Fuente: Entrevistas a youtubers.

Elaboración propia.

Como se puede comprobar en la tabla anterior, los valores de producción de los tres youtubers entrevistados son similares entre sí y diferentes a los que manejan los medios. Las cámaras utilizadas son semiprofesionales y, dentro de ese espectro, de gama media. Las puntuaciones de cada una (SnapSort, 2019) indican que están en un rango muy similar. Para el medio de YouTube, resultan más que suficiente, ya que permiten grabar videos ajustados a los estándares de calidad de la plataforma, mientras que esto sería insuficiente para los medios tradicionales. Algo similar ocurre con los equipos de iluminación y audio. De los tres youtubers entrevistados, solo Daniela Acosta utiliza equipos de iluminación, lo cual es consistente con la temática de su canal (fashion vlogger), que requiere de un tratamiento más adecuado de la imagen de la presentadora, en tanto que la misma sirve como valor agregado para la promoción de marcas. Por otro lado, El Vicho es el único que trabaja con equipos de audio más especializados, aunque esto no necesariamente ofrece un valor agregado que sea requisito para su rubro o modelo de negocio. 
En cuanto a los programas de edición, todos utilizan Adobe Premiere Pro. No especifican la versión utilizada, ni tampoco el grado de dominio del mismo, pero al realizar un análisis de los tres canales, se puede concluir que el uso que hacen de dicho programa es limitado y, por ende, de menor "riqueza" que el que es posible encontrar en los medios tradicionales. Sin embargo, en los tres casos, se ajustan al estándar de la mayoría de youtubers, tanto del Perú como de otros países. En esa misma línea, en los tres casos se ve el uso de material de terceros, libre de derechos de autor, de modo que no invierten en material extra de pago que les ofrezca exclusividad en el uso de los mismos. Esto incide en la identificación de cada canal de YouTube, en tanto que el material usado por muchos dificulta la asociación con un solo youtuber. No obstante, de la misma forma que se ha mencionado hasta ahora, es una práctica común en el medio de YouTube, que tiene como fundamento abaratar costos y evitar reclamos innecesarios de copyright, para mantener operativa la plataforma.

Finalmente, en el proceso de producción es en donde se encuentran las mayores diferencias. En la fase de preproducción, tanto El Vicho como Karina Arancibia trabajan con pautas simples, el primero con un guion manuscrito y la segunda con la guía que le ofrece la receta del día. Solo Daniela Acosta escribe su pauta recién después de grabar, como guía para el proceso de postproducción. Tanto Karina como Daniela, requieren de una puesta de set, que incluye la recolección de materiales (ingredientes e implementos de cocina, en el caso de Karina: y vestuario y maquillaje en el caso de Daniela), lo mismo que maquillaje y peinado (ambas se lo proporcionan a sí mismas). Únicamente El Vicho toma la precaución de contar con cambios de ropa, suficientes para la cantidad de videos que grabe en un día.

Ya en la fase de producción, los tres youtubers graban sus propios videos, aunque Daniela cuenta con una fotógrafa, que se encarga de las sesiones finales cada prenda de ropa utilizada. En el caso de El Vicho, no lleva un control de calidad de lo grabado, de modo que es posible que llegue a notar que la calidad de un video es baja recién en la fase de postproducción, ante lo cual se deshace de dicho material. Por último, en la fase de postproducción, solo Daniela cuenta con editor de video. Los demás lo realizan por su cuenta; Karina con una agenda programada y, El Vicho en su tiempo libre, al final de cada jornada laboral. Todos estos son factores similares a los descritos por otros youtubers, pero que resultan muy simples o insuficientes para los medios tradicionales. 


\section{2. ¿Cómo se caracteriza el fenómeno de los youtubers desde una perspectiva comunicacional?}

En la Tabla 3.4, que se verá a continuación, se presenta una caracterización del fenómeno social de los youtubers desde el punto de vista comunicacional, que, de algún modo, también pudiera explicar el posicionamiento presente y futuro de esos actores sociales y culturales de la era digital. La primera característica consiste en la empatía que estos personajes han logrado con sus públicos. En buena medida, el éxito de los youtubers pudiera estar asociado a su capacidad para colocarse en el lugar de los usuarios y comprender, cabalmente, sus necesidades y problemas más acuciantes, al tiempo que generen alternativas de solución u orientación.

Otro aspecto que destacan los entrevistados como características de los youtubers en el plano de la comunicación, es la cualidad que estos presentan como productores de los contenidos que difunden. Este hecho contrasta con los medios de comunicación tradiciones, en los cuales, quienes producen los contenidos, son diferentes de quienes los difunden. No obstante, este rol tiende a ser compartido en la medida en que se incrementa el número de seguidores, la fama y el presupuesto que manejan los youtubers.

Una de las características que presentan los youtubers entrevistados, es que su objetivo es generar soluciones a problemas y necesidades que presentan los usuarios, mediante alternativas que están al alcance de ellos mismos.

Tabla 3.4.

¿Cómo se caracteriza el fenómeno youtubers desde una perspectiva comunicacional?

\begin{tabular}{|l|l|l|}
\hline \multicolumn{1}{|c|}{ Aspecto } & \multicolumn{1}{|c|}{ Youtuber } & \multicolumn{1}{c|}{$\begin{array}{c}\text { Presentación de producción } \\
\text { tradicional }\end{array}$} \\
\hline Empatía & Elevada. & Baja. \\
\hline $\begin{array}{l}\text { Generación de } \\
\text { contenido }\end{array}$ & Generador de contenidos. & Otros generan los contenidos. \\
\hline Objetivos & $\begin{array}{l}\text { Solución de problemas y } \\
\text { necesidades de los usuarios. }\end{array}$ & Información y entretenimiento. \\
\hline $\begin{array}{l}\text { Pedagogía de la } \\
\text { comunicación }\end{array}$ & $\begin{array}{l}\text { Pedagogía de lo fácil y la } \\
\text { facilitación. Enfocada en } \\
\text { públicos específicos. }\end{array}$ & Pedagogía general. \\
\hline $\begin{array}{l}\text { Conexión personal } \\
\text { con el publico }\end{array}$ & $\begin{array}{l}\text { Compartes gustos y preferencias. } \\
\text { Cercanía. }\end{array}$ & Relación distante. \\
\hline
\end{tabular}

(continuación) 
(continúa)

\begin{tabular}{|l|l|l|}
\hline Publicidad & $\begin{array}{l}\text { Compromiso personal con los } \\
\text { productos que anuncia. }\end{array}$ & Publicidad impersonal. \\
\hline $\begin{array}{l}\text { Conocimientos sobre } \\
\text { los temas tratados }\end{array}$ & $\begin{array}{l}\text { Tiende a ser expertos en los } \\
\text { temas que trata y se enfoca en } \\
\text { ellos. }\end{array}$ & $\begin{array}{l}\text { Se prepara en los temas para } \\
\text { hacer los programas. }\end{array}$ \\
\hline $\begin{array}{l}\text { Fidelidad de los } \\
\text { seguidores }\end{array}$ & Elevada y emocional. & Baja y distante. \\
\hline Profesionalidad & $\begin{array}{l}\text { Flexibilidad en la } \\
\text { profesionalidad. Generalmente } \\
\text { responde a experiencias y } \\
\text { convicciones personales del } \\
\text { youtuber. }\end{array}$ & Elevado nivel profesional. \\
\hline $\begin{array}{l}\text { Segmentación del } \\
\text { mercado }\end{array}$ & Elevada segmentación. & Relativa segmentación. \\
\hline
\end{tabular}

Fuente: Elaboración propia.

Esta situación contrasta con los comunicadores tradicionales que, generalmente, tienen como objetivo informar y entretener. No obstante, también existen youtubers que cumplen las funciones de comunicadores sociales. Aun así, la muestra de entrevistas solo generó resultados referidos a comunicadores digitales que se enfocan en brindar soluciones a los problemas e inquietudes de sus seguidores o suscriptores.

Otra característica de los youtubers de éxito, que emerge de las entrevistas y que se puede observar en la Tabla 3.4 (p. 27), es que logran desarrollar lo que se puede denominar "una pedagogía de lo fácil" que, consecuentemente, facilita a los usuarios la solución de problemas y necesidades personales. En contraste, los comunicadores tradicionales, dadas las funciones esenciales de entretener e informar, apelan a lo que pudiera denominarse una pedagogía general, pensada para diversos públicos.

Una cualidad de los youtubers que logran trascender en cuanto a seguidores y suscriptores, según los entrevistados y lo visto en la Tabla 3.4 (p. 27), logran establecer una relación cercana y personal con sus seguidores (o al menos crean esa sensación), que es propiciada por el hecho de compartir valores y preferencias comunes. Esto se diferencia de los comunicadores tradicionales, donde las condiciones estructurales de los medios no facilitan el acercamiento entre comunicadores y usuarios.

Según la Tabla 3.4 (p. 27), otro rasgo que distingue a los youtubers de éxito consiste en asumir un compromiso personal con los productos que anuncian en su publicidad, de los cuales, generalmente, son consumidores. Hecho que contrasta con los 
comunicadores sociales tradicionales, quienes por lo general asumen la publicidad como un asunto de carácter profesional.

Otra característica común en los youtubers que logran un elevado número de suscriptores, es que manejan amplios y profundos conocimientos sobre los temas que tratan, con los cuales, además, unen vínculos personales y vocacionales. En los comunicadores tradicionales, esta situación presenta una condición de carácter contingente.

Según los entrevistados, los youtubers logran mayores niveles de fidelidad con sus seguidores cuando se les compara con los comunicadores tradicionales. Quizás los rasgos de estos actores de la mediática digital, mencionados hasta ahora, puedan resultar explicativos de esa fidelidad.

La flexibilidad en la profesionalidad y los vínculos personales del youtubers con los contenidos que comunican, constituyen otros de los rasgos que presentan los youtubers desde el punto de vista comunicacional. Se puede así afirmar que, la mayoría de los youtubers, en sus inicios, parten de su propia experiencia de vida y, en la medida en que aumentan los seguidores y los niveles de ingreso, asumen sus funciones con mayores niveles de profesionalidad.

Finalmente, el otro rasgo del éxito comunicacional de los youtubers, según la Tabla 3.4 (p. 27), consiste en tener la capacidad o intuición para segmentar, de modo pertinente, el mercado en el que desean enfocarse, así como para identificar las necesidades o problemas sobre los que deben enfocar los contenidos que va a difundir.

\section{3. ¿De qué manera influyen los youtubers como modalidad emergente de producción audiovisual en el Perú?}

En esta sección, se aborda la problemática de los youtubers como una modalidad emergente de la producción audiovisual en la era digital. En la siguiente tabla, se describen las características de esa modalidad. 
Tabla 3.5.

El youtuber como modalidad emergente de producción audiovisual

\begin{tabular}{|c|c|c|}
\hline Características & Youtuber & Tradicional \\
\hline $\begin{array}{l}\text { Fases de la } \\
\text { producción }\end{array}$ & $\begin{array}{l}\text { Aplicación flexible de los procesos de } \\
\text { la producción audiovisual. La } \\
\text { flexibilidad disminuye en la medida } \\
\text { que aumenta la profesionalización de } \\
\text { youtuber. }\end{array}$ & $\begin{array}{l}\text { Aplicación rígida de las siguientes } \\
\text { fases: investigación, preproducción, } \\
\text { producción, realización, } \\
\text { postproducción y mercadeo. }\end{array}$ \\
\hline Inversión & $\begin{array}{l}\text { Bajo presupuesto. Puede aumentar con } \\
\text { la profesionalización y fama del } \\
\text { youtuber. }\end{array}$ & $\begin{array}{l}\text { Alto presupuesto por requerimientos de } \\
\text { personal especializado e } \\
\text { infraestructura. }\end{array}$ \\
\hline $\begin{array}{l}\text { Producción de } \\
\text { contenidos }\end{array}$ & $\begin{array}{l}\text { El youtuber produce el contenido. La } \\
\text { situación puede variar en dependencia } \\
\text { de la profesionalización y la fama. }\end{array}$ & $\begin{array}{l}\text { Existen especialistas para la } \\
\text { producción de contenidos. }\end{array}$ \\
\hline $\begin{array}{l}\text { Público de } \\
\text { mayor impacto }\end{array}$ & $\begin{array}{l}\text { Millenial, público juvenil. } \\
\text { Alejamiento de los medios } \\
\text { tradicionales. }\end{array}$ & Adultos contemporáneos. \\
\hline $\begin{array}{l}\text { Acceso a los } \\
\text { contenidos }\end{array}$ & Abierto y democrático. & Restringido a quien pueda pagarlos. \\
\hline Profesionalidad & $\begin{array}{l}\text { Tendencia al trabajo empírico, aunque } \\
\text { la profesionalización se vuelve } \\
\text { imperativa con el prestigio del } \\
\text { youtuber. Generalmente se opta por } \\
\text { autoformación por medios } \\
\text { tecnológicos. }\end{array}$ & $\begin{array}{l}\text { Equipo de especialistas en los } \\
\text { diferentes aspectos de la producción. }\end{array}$ \\
\hline
\end{tabular}

Fuente: Entrevistas a youtubers, productores audiovisuales y analistas de medios. 2019.

Elaboración propia.

La modalidad tradicional de producción audiovisual establece que la misma se cumple, de manera lineal, en las siguientes fases: investigación de mercado, preproducción, producción, realización, postproducción y mercadeo. Teóricamente, se supone que el cumplimiento de estas fases es una condición importante para el éxito de la misma. No obstante, según la Tabla 3.5, los entrevistados coinciden en que los youtubers manejan el proceso de producción audiovisual de un modo flexible, particularmente en sus inicios, y luego, en la medida del crecimiento de sus seguidores y recursos económicos, tienden a concebir su trabajo de un modo más profesional, atendiendo a los fundamentos teóricos del marketing digital, lo cual supone, de alguna manera, cumplir con las fases de producción audiovisual tradicional.

En los que respecta a los niveles de inversión, los entrevistados coinciden en que la producción audiovisual tradicional supera con creces a la producción audiovisual de los youtubers. Mientras que la primera amerita la participación de un equipo de 
especialistas, así como el uso de sofisticados equipos tecnológicos, además de una logística adecuada; en muchas de las producciones de los youtubers solo participan ellos, de modo individual, apelando al uso de un teléfono inteligente.

El youtuber como productor de contenidos, el enfoque a la población millenial que se encuentra alejada de los medios tradicionales, el acceso democrático a los contenidos y el carácter no profesional de la comunicación, según la Tabla 3.4 (p. 27), constituyen rasgos característicos que soportan la idea de los youtubers, como una modalidad emergente de la producción audiovisual frente a las modalidades usadas por los medios tradicionales.

En este sentido, tanto el productor audiovisual de TV, César Arana, y un especialista en el tema, el profesor Subauste, comparten la percepción de que los youtubers representan una forma diferente de producción audiovisual respecto a los medios tradicionales. Básicamente, la diferencia está marcada por la velocidad en la creación, la interactividad con el público, el tipo de público al que se dirigen, la reducción en los costos y presupuestos, así como en la forma de crear contenidos y en el impacto a nivel de la transmisión de información.

Por su parte, el Prof. Subauste comenta: "La interactividad es lo primero que marcó la diferencia con los medios tradicionales; la cuestión de la emisión en vivo ha sido un proceso posterior, pero, para comenzar, el hecho de que tú pudieras conectarte en directo a través de solo texto, significó gradualmente la aparición del chat como un mecanismo de comunicación inmediato, que cambió y transformó la lógica de otros medios de comunicación" (entrevista personal, Subauste, 2019).

Complementariamente, César Arana comenta: "Estamos hablando de variables de producción completamente distintas, completamente diferentes; eso ha permitido que se abaraten costos, que se popularice, se democratice un poco el contenido para plataformas digitales. Ellos pueden producir su contenido desde un celular sin inconvenientes. Entonces son formas de producir completamente distintas" (entrevista personal, C. Arana, 2019).

Entre los entrevistados, se perciben algunas divergencias, pues el productor considera que el proceso de producción audiovisual se cumple con rigurosidad y sistematicidad en los medios tradicionales, mientras que la producción audiovisual de los youtubers es más informal, espontánea y menos sistemática. Por otra parte, el especialista 
en medios digitales menciona que el proceso que va desde la concepción de la idea, la preproducción, producción y postproducción también se cumplen en muchos de los casos de youtubers, pero con la diferencia de velocidad y facilidad con que se ejecutan tales procesos, que no exigen una complejidad estructural y recursos para ello.

Tales diferencias se pueden apreciar en los siguientes fragmentos de sus discursos: "El proceso de producción tradicional pasa por diferentes etapas claramente diferenciadas. Tienes una primera etapa de investigación y de preparación del proyecto, una segunda etapa de preproducción del proyecto, tienes una tercera etapa de producción y realización en sí y tienes una última etapa de postproducción y, dependiendo del tipo de proyecto que hayas abordado, tienes una cuarta etapa en la cual te dedicas a ver temas de promoción, distribución y lanzamiento. Por lo poco que sé acerca de la forma de producir de los youtubers, yo no creo que estén respetando mucho ese proceso" (entrevista personal, C. Arana, 2019).

Por otro lado, se afirma al respecto: "No ha cambiado el concepto de producción en los streaming o medios digitales; lo que ha cambiado es la dinámica y la facilidad de reaccionar y tomar decisiones. Lo que tú encuentras cuando analizas el sistema de producción de los youtubers más reconocidos es que finalmente también efectúan un proceso similar" (entrevista personal, Subauste, 2019).

Otro criterio diferencial entre los entrevistados radica en que, según el primero, la confianza en las publicaciones de los medios virtuales es relativamente baja, situación que empuja a los usuarios al cotejo de las mismas con los referentes que ofrecen los medios tradicionales, que, según él, ofrecen mayor veracidad: "Siempre el público va a pretender recurrir a una plataforma oficial tradicional para confirmar si eso que está viendo en Facebook, Instagram o cualquier otra plataforma digital es realmente cierto o no" (entrevista personal, C. Arana, 2019).

Paralelamente, el especialista en medios digitales, considera que progresivamente los medios tradicionales deben ir ajustando sus modos y formas a las plataformas virtuales, si no quieren ser sustituidos por completo: “Con el pasar de los años, los usos y costumbres van a cambiar y los millenials van a estar en la cabeza, y ellos son los principales usuarios de medios digitales. Ya hoy en día es raro ver a alguien escuchando radio o viendo televisión. Es más común ver a gente pegada a una Tablet o a su teléfono celular" (entrevista personal, Subauste, 2019). 
Sobre el tema de los recursos económicos para la producción audiovisual, los entrevistados concuerdan en que los medios digitales han representado una disminución de costos significativa, que ha revolucionado el acceso a la producción, difusión e impacto de las creaciones audiovisuales, en ese sentido, el especialista en medios señala que "Los medios convencionales siguen demandando inversiones muy altas en el tema de equipos, infraestructura y de acceso a los mecanismos de distribución y difusión de estos contenidos; mientras que lo digital siempre, desde un principio, ha abaratado costos. Entonces, la diferencia marcada es en lo que es el tema económico para una producción más trabajada" (entrevista personal, Subauste, 2019).

Asimismo, el productor complementa: "en el sistema de producción tradicional te hablo de un mayor costo de producción a todo nivel: a nivel de inversión, personal, a nivel de recurso. Lo que es la producción para plataformas digitales como los youtubers, manejan otro nivel de inversión, ya que estamos hablando de un tipo de contenido totalmente diferente que maneja otras variables. Un youtuber puede generar su contenido propio, él mismo, sin necesidad de un equipo que trabaje con él" (entrevista personal, C. Arana, 2019). 


\section{CONCLUSIONES}

Los medios de producción audiovisual en la era digital se agrupan principalmente en los “tradicionales", lo que alude a su carácter no virtual o no mediados por el Internet, y aquellos que sí lo están, que se conocen como medios digitales o new media. Como se ha podido observar en los resultados obtenidos, ambos poseen algunos aspectos que podrían considerarse semejanzas, mientras que existen otros que establecen una distinción clara entre ellos. Una conclusión al respecto es que, aunque en los medios digitales se cumpla la misma serie de etapas para obtener un producto audiovisual, las formas en que estas se completan, difieren del modo en que se ejecutan en los medios tradicionales, especialmente si se considera el tiempo de producción y los recursos utilizados.

En los medios tradicionales, el proceso de concepción de una idea base, la preproducción, la producción y la postproducción, son etapas que se ajustan a ciertos cronogramas, dependiendo del talento humano con el que se cuenta, del presupuesto disponible, de la planificación, logística y coordinación; mientras que muchos youtubers desarrollan actividades puntuales que podrían representar, a grandes rasgos, tales procesos y etapas; sin embargo, la relación dinámica y acelerada entre ellas marca la diferencia que se expresa, a su vez, en el resultado, tiempo de respuesta y público al que se dirigen. Lo mismo aplica para los instrumentos que utilizan (cámaras, equipos de iluminación y audio, programas de edición, recursos de terceros, etc.) para su producción, siendo de carácter menos profesional o dándole un uso más limitado, en el caso de los youtubers en contraste con los medios tradicionales.

Ahora bien, es preciso ubicar el fenómeno youtuber en el contexto de las transformaciones sociales, culturales y tecnológicas de la era digital y la sociedad del conocimiento, los cuales actúan como factores estructurales, que direccionan las creaciones de los youtubers hacia el segmento de los niños y jóvenes, al tiempo que su incidencia en los restantes grupos etarios es relativamente baja. Otra característica es la presencia de múltiples modos de interacción, que permite una comunicación de los productores con los usuarios en un tiempo real o al menos en un muy corto lapso de tiempo, mediante los chats, el número de vistas, los comentarios, los likes, suscripciones, las veces que el contenido es compartido, entre otras estrategias. Finalmente, en la 
distinción entre ambas modalidades de producción audiovisual, destaca el aspecto referido a la inversión, pues, generalmente, en los medios tradicionales esta conlleva una inversión de una significativa cantidad de recursos humanos, materiales y financieros; mientras que muchos youtubers requieren una cantidad mínima de recursos para generar sus productos audiovisuales (por ejemplo, solo usan materiales de terceros libres de derechos de autor).

En cuanto a los youtubers con más vistas en Perú, la lista está liderada por los siguientes: (1) "Shidori Drawblogs", con 1.31 mil millones de vistas; (2) "whatdafaqshow", con 714.1 millones de vistas (3) "Whatthechic", con 467.15 millones de vistas; (4) “ElioDt”, con 477.62 millones de vistas; (4) “Esperanza y Ana Celia Rosas”, con 406.5 millones de vistas; y, por último, (5) "tallermanualperu”, con 261.22 millones de vistas ${ }^{6}$. Este dato es importante, pues refleja que el Perú maneja cifras similares a los demás países latinoamericanos, en términos de la cantidad de vistas que tienen sus youtubers más exitosos, descartando casos muy puntuales de México, Argentina, Ecuador y Chile, que superan por mucho esta cantidad de vistas, y en realidad compiten con los youtubers con más vistas de Estados Unidos y Europa.

En cuanto a la pregunta de investigación “¿de qué manera influyen los youtubers como modalidad emergente de producción audiovisual en la era digital?", es importante acotar que existe cierto consenso en relación a considerar a los youtubers como una modalidad nueva y emergente de producción audiovisual, que desafía las formas, métodos y contenidos de la producción audiovisual tradicional, revelando exigencias de transformación de esta para adaptarse a las condiciones de la nueva era digital. Se considera que la producción de los youtubers está dirigida fundamentalmente a un público joven e infantil pero progresivamente esta modalidad avanza en la conquista de nuevos públicos y nuevos espacios. Es conveniente señalar, además, el uso complementario y adaptativo que vienen dando los medios de comunicación tradicionales a los espacios virtuales de los que disponen.

Adicionalmente, es importante hacer notar que los youtubers, como modalidad emergente de producción audiovisual, ponen al descubierto el advenimiento de nuevas lógicas comerciales, en las que privan relaciones económicas poco mediadas, más directas, que devienen del proceso de monetización impulsado por la extraordinaria

\footnotetext{
${ }^{6} \mathrm{https} / / /$ es.noxinfluencer.com/youtube/channel-calculator/UCDNedXg30zdGBBe4RlvLM1Q
} 
rapidez con que algunos productores de contenido en YouTube llegan a un significativo número de usuarios, espacios ideales para la promoción de bienes y servicios de empresas ubicadas dentro de un territorio y más allá de sus fronteras.

Finalmente, podría destacarse que la creación audiovisual de los youtubers se define por su apertura hacia la experimentación, el ensayo y error, nuevos formatos, métodos, contenidos y narrativas; aun cuando desde este espacio se haga un uso innovador de técnicas desarrolladas en el seno de los medios tradicionales de producción audiovisual. En consecuencia, es posible concluir que los youtubers constituyen una forma emergente de encarar la producción audiovisual que es necesario comprender en el contexto de las particularidades culturales y tecnológicas de la era digital que experimenta la humanidad.

De esta manera, se puede llegar a la conclusión de que realmente los youtubers representan una modalidad emergente de producción audiovisual que debe ser analizada en el contexto de la naturaleza cambiante y compleja de esta era digital, pero que es importante destacar que, para el momento, las ganancias derivadas de la monetización con la plataforma son incipientes e insuficientes, como para que puedan dedicarse a sus canales de forma profesional o como principal fuente de ingreso. Esta es una realidad que se observa sin distinción, también, en el contexto peruano.

En ese sentido, y tomando en cuenta experiencias como las derivadas de YouTube Red, que contrata a youtubers de gran acogida para realizar producciones similares a las de los medios tradicionales, o la de los medios tradicionales, que migran parcialmente hacia portales como YouTube; se entiende que es poco probable que los medios tradicionales desaparezcan del todo. En el Perú se observa solo lo segundo, pues las plataformas de streaming aún no invierten en youtubers peruanos para sus producciones. La cuestión es que, para poder subsistir, ambas partes tendrán que adaptarse. Los youtubers cada vez tendrán más competencia, y esto les exigirá profesionalizarse para lograr la distinción entre sus competidores, y los medios tradicionales tendrán que acercarse al público de forma más directa, por redes sociales y plataformas de video como YouTube.

El ecosistema comunicacional, como cualquier otro ecosistema, evoluciona a partir de las interacciones entre las diferentes partes de la cadena de poder, y es por eso que no se puede asegurar que el futuro de los medios ha quedado sellado y definido dentro 
de YouTube. La dinámica actual todavía tiene tensiones complejas por resolver, que podrían cambiar el panorama de manera radical en los próximos años, hacia escenarios como los pronosticados, como también a otros, muy diferentes a estos. 


\section{RECOMENDACIONES}

A continuación, se detallarán las recomendaciones:

- Debe fomentarse el desarrollo de investigaciones vinculadas a las prácticas de los youtubers y el impacto de estas en los métodos de producción audiovisual.

- Los medios tradicionales de producción audiovisual deben analizar los mecanismos y procesos de adaptación a la era digital, que les permitan ganar nuevos espacios entre los usuarios y hacer sostenible su actividad.

- Se sugiere monitorear y sistematizar los nuevos desarrollos de los medios de producción audiovisual, con el fin de identificar los saltos cualitativos que provoca la revolución tecnológica en los modos de vida actual y futura.

- Es relevante idear estrategias para potenciar los usos educativos, instructivos e informativos de los canales de YouTube, a fin de que estos se posicionen en las preferencias de los usuarios. Así, se busca que estos contribuyan a fortalecer los niveles educativos de la población. 


\section{REFERENCIAS}

Aguilar, J. (2018). YouTube como herramienta para la construcción de la sociedad del conocimiento. ReHuSo: Revista de Ciencias Humanísticas y Sociales. 3(1), 1-16. Recuperado de www.revistas.utm.edu.ec/index.php/Rehuso

Alberich, P., y Roig, A. (2005). Comunicación audiovisual digital. Nuevos medios, nuevos usos, nuevas formas. Barcelona: Editorial UOC.

Almaraz, I, González, M., y Ors, C. (2013). Análisis de los mensajes audiovisuales del Tercer Sector en YouTube. Revista Latina de Comunicación Social, (68), 14-27. Recuperado de https://dialnet.unirioja.es/servlet/articulo?codigo=4209719

Alonso, R. (2002). La influencia de las nuevas tecnologías en la cultura audiovisual contemporánea. Tarbiya, revista de Investigación e Innovación Educativa, (31). 67-80. Recuperado de https://revistas.uam.es/tarbiya/article/view/7397

Antolín Prieto, R. (2012). YouTube como paradigma del vídeo y la televisión en la web 2.0. Tesis de doctorado. Universidad Complutense de Madrid, Madrid, España.

Bartolomé, A. (1987). Análisis de la producción y aplicación de programas audiovisuales didácticos. Barcelona: Universitat de Barcelona.

Berzosa, M. (2017). Youtubers y otras especies. Barcelona: Ariel-Fundación Telefónica.

Braga, J. (2011). Dispositivos interacionais. Encontro Anual da Compós, 20, 1-15. Recuperado de http://www.compos.org.br/data/biblioteca_1657.pdf

Collarte, E. (2009). Los jóvenes y su visión de mundo. Producción y publicación de videos en Youtube. Revista F@ ro-Tesis, 5(9), 1-7. Recuperado de http://web.upla.cl/revistafaro/EduardoMacíasCollarte

De Oliveira, M. (2017). Direito à Comunicação no YouTube: perspectivas teóricas nas pesquisas da Intercom. $40^{\circ}$ Congresso Brasileiro de Ciências da Comunicação Curitiba. Universidade de São Paulo. Brasil.

Fidler, R. (1998). Mediamorfosis: comprender los nuevos medios. Buenos Aires: Saber.

Gallardo, J., y Jorge, A. (2010). La baja interacción del espectador de vídeos en Internet: caso Youtube España. Revista Latina de Comunicación Social, 10(3). 421-435. Recuperado de https://repositorio.ucjc.edu/handle/20.500.12020/622

Gómez, N. (2014). Youtubers: fenómeno de la comunicación y vehículo de transmisión cultural para la construcción de identidad adolescente. Tesis de maestría. Universidad de Cantabria, Cantabria, España.

Gómez, O. (2018). Análisis de la narrativa audiovisual de los Youtubers y su impacto en los jóvenes colombianos. Tesis de doctorado. Universidad de Málaga, Málaga, España. 
González, E, y Chica, D. (2018). Conducta de los suscriptores en YouTube: estudio de caso del canal EnchufeTv. Dixit, (28), 56-71. Recuperado de http://www.scielo.edu.uy/scielo.php?pid=S0797-

36912018000100056\&script=sci_abstract\&tlng=en

Guzmán, A, y Moral, M. (2014). Tendencias de uso de YouTube: optimizando la comunicación estratégica de las universidades iberoamericanas. Observatorio, 8(1), 69-94. Recuperado de http://obs.obercom.pt

Hernández, C. (2017). Transición de la tecnología analógica a la digital. Recuperado de http://cidac.org/esp/uploads/1/Transici_n_de_la_televisi_n_anal_gica_a_la_dig ital_PDF.pdf

Hernández, R., Fernández, C., y Baptista, M. (2014). Metodología de la investigación. (6ta ed.). México D.F.: McGraw-Hill.

Hidalgo, T., y Segarra, J. (2017). El fenómeno youtuber y su expansión transmedia. Análisis del empoderamiento juvenil en redes sociales. Fonseca, Journal of Communication, 15, 43-56. Recuperado de http://revistas.usal.es/index.php/21729077/article/view/fjc2017154356

Jódar, J. (2010). La era digital: nuevos medios, nuevos usuarios y nuevos profesionales. Razón y Palabra, 15(71), 1-11. Recuperado de https://www.redalyc.org/html/1995/199514914045/

León, L. (2018). Niños youtubers y el proceso de creación de videos: evidencia de competencias transmedia en acción. Comunicación y Sociedad, 33(15), 115-137. doi:10.32870/cys.v0i33.7080

Lloret, N., y Canet, F. (2008). Nuevos escenarios, nuevas formas de expresión narrativa: La Web 2.0 y el lenguaje audiovisual. Hipertext.net, 6. Recuperado de https://www.upf.edu/hipertextnet/numero-6/lenguajeaudiovisual.html\#Conclusiones

Londoño, E., y Castañeda, J. (2014). Caracterización del youtuber. A partir de El Penúltimo TV e Internautismo Crónico como casos de estudio. Recuperado de https://issuu.com/elizabethlondono/docs/caracterizaci_n_del_rol_del_youtub

López, A. (2016). Youtubers. Nueva lógica comercial y narrativa en la producción de contenidos para la web. Letra. Imagen. Sonido: Ciudad Mediatizada, (15), 225241. Recuperado de https://dialnet.unirioja.es/servlet/articulo?codigo=5837809

Losada, I. (2016). Poder audiovisual: YouTube como aliado de los medios de comunicación tradicionales en España para la difusión de contenido. Tesis de pregrado. Universidad Central de Cataluña, Cataluña, España.

Márquez, I., y Ardévol, E. (2018). Hegemonía y contrahegemonía en el fenómeno youtuber. Desacatos. Revista de Ciencias Sociales, (56), 34-49. doi:10.29340/56.1876

Martín, J. (1998). De los medios a las mediaciones: comunicación, cultura y hegemonía. Caracas: Convenio Andrés Bello. 
Montesinos, I. (2014). Youtube como recurso audiovisual para el desarrollo de la comunicación oral del idioma inglés en estudiantes del 2 do de bachillerato de la especialidad Secretariado Bilingüe del Instituto Tecnológico Superior Gran Colombia, período lectivo 2012-2013. Tesis de pregrado. Universidad Central del Ecuador, Quito, Ecuador.

NoxInfluencers (2020a). Clasificación de Daniela Acosta. Recuperado el 29 de enero de 2020 de https://es.noxinfluencer.com/youtube/channelcalculator/UCDCeDvdivmwyEW18i7hDLxQ

NoxInfluencers (2020b). Clasificación de El Vicho. Recuperado el 29 de enero de 2020 de https://es.noxinfluencer.com/youtube/channelcalculator?url=https\%3A\%2F\%2Fwww.youtube.com\%2Fuser\%2FMakeupbyDa nia

NoxInfluencers (2020c). Clasificación de Fucsia Pastelería Casual. Recuperado el 29 de enero de 2020 de https://es.noxinfluencer.com/youtube/channelcalculator/UCDNedXg30zdGBBe4RlvLM1Q

NoxInfluencers (2020d). Los 250 youtubers con más suscriptores en Perú. Recuperado el 29 de enero de 2020 de https://es.noxinfluencer.com/youtube/channelcalculator/UCDNedXg30zdGBBe4RlvLM1Q

Onaindia, J., y Madedo, F. (2013). La industria audiovisual. Palermo Business Review, 18, 183-217. Recuperado de https://www.palermo.edu/economicas/cbrs/pdf/rwe8/PBRespecial_05onaindiaW EB.pdf

Pérez, J., y Gómez, F. (2013). Nuevos formatos audiovisuales en Internet: cuando el usuario es quien innova. En M. De Salas y E. Mira, Prospectivas y tendencias para la comunicación en el siglo XXI (167-187). Madrid: CEU Ediciones.

Reyes, P. (2007). La televisión analógica digital y estándares mpeg. Recuperado de http://www.icicm.com/files/TV_DIGITAL_ANALOGICA_Y_MPEG.doc

Quintero, D. (2017). Códigos comunicativos de la producción audiovisual masiva en YouTube. Revista Comunicación, 15, 77-90. Recuperado de http://www.revistacomunicacion.org/pdf/n15/Articulos/A6_Quintero-Codigoscomunicativos-de-la-produccion-audiovisual-masiva-en-YouTube.pdf

Rodríguez, I. (2017). Marketing experiencial con influencers: los nuevos impulsores de la industria cinematográfica. Tesis de pregrado. Universidad del País Vasco, Vizcata, España.

Roger, V. (2010). Nuevas tecnologías aplicadas a la realización de la información audiovisual y retransmisiones deportivas. Tesis de doctorado. Universidad Politécnica de Valencia, Valencia, España.

Rufí, J., y Pérez, F. (2013). Nuevos formatos audiovisuales en Internet: cuando el usuario es quien innova. Prospectivas y tendencias para la comunicación en el siglo XXI. Recuperado 
https://www.uchceu.es/actividades_culturales/2013/congresos/documentos/Fco_ Javier_Gomez_Perez_Jose_Patricio_Perez_Rufi.pdf

Sabich, M. y Steinberg, L. (2017). Discursividad youtuber: afecto, narrativas y estrategias de socialización en comunidades de Internet. Revista Mediterránea de Comunicación/Mediterranean Journal of Communication, 8(2), 171-188. doi:10.14198/MEDCOM2017.8.2.12

SnapSort (2019a). Canon Rebel T4i vs Sony Alpha A5100. Recuperado de http://snapsort.com/compare/Canon-Rebel-T4i-vs-Sony-Alpha-A5100

SnapSort (2019b). Canon Rebel T5i vs Sony Alpha A5100. Recuperado de http://snapsort.com/compare/Canon-Rebel-T5i-vs-Sony-Alpha-A5100

Sora, C. (2015). Etapas, factores de transformación y modelo de análisis del nuevo audiovisual interactivo online. El profesional de la información, 24(4), 424-431. Recuperado de https://recyt.fecyt.es/index.php/EPI/article/view/epi.2015.jul.09

Strauss, A. y Corbin, J. (2000). Bases para la investigación cualitativa. Técnicas y procedimientos para desarrollar la teoría fundamentada. Antioquia: Universidad de Antioquia.

Tórtola, A. (2017). La televisión en la era de las nuevas tecnologías. Tesis de maestría. Universidad de Buenos Aires, Buenos Aires, Argentina. 
ANEXOS 


\section{ANEXO 1: Entrevista sobre comparación entre la producción audiovisual tradicional y la producción audiovisual emergente de los youtubers}

A continuación, se presentan algunas interrogantes que pretenden guiar la entrevista con un productor audiovisual de TV y un especialista en el tema de la producción audiovisual, cuyo propósito es conocer sus apreciaciones e interpretaciones sobre los elementos que distinguen a la producción audiovisual emergente de los youtubers, de la producción audiovisual tradicional, en el marco de aspectos técnicos, linguíísticos, económicos, entre otros.

1. Según su apreciación ¿qué distingue a la producción audiovisual emergente (youtuber) de la producción audiovisual tradicional en cuanto al ejercicio de los roles inherentes a una creación audiovisual (actor, autor, productor, difusor y consumidor)?

2. ¿Cuál es su apreciación sobre las formas de interacción productor (creador) audiencia que definen a las producciones audiovisuales tradicionales y a las emergentes (o de los youtubers)?

3. En términos de la promoción y viralización de los productos audiovisuales ¿cuáles son, según su opinión, los rasgos distintivos de los youtubers y de los productores estándar?

4. En cuanto a los contenidos abordados ¿qué diferencias aprecia usted entre la producción audiovisual estándar (tradicional) y la producción audiovisual emergente (youtubers)?

5. ¿Qué observaciones podría exponernos usted sobre la calidad de las producciones y nivel de profesionalidad de las producciones audiovisuales de los youtubers, respecto a las producciones audiovisuales tradicionales?

6. ¿Qué propósitos de la producción audiovisual en los youtubers los diferencia o los asemeja a los productores audiovisuales estándar?

7. ¿Qué piensa usted acerca del tiempo de duración de las producciones audiovisuales tradicionales y de las desarrolladas por los youtubers? ¿qué diferencias y qué lógicas intervienen en relación a este factor? 
8. Sobre el proceso de preproducción - producción - postproducción ¿cómo se desarrollan en la producción audiovisual tradicional y en la emergente (youtuber)?

9. ¿Cómo percibe usted el proceso de retroalimentación en ambos tipos de producciones audiovisuales (tradicionales y emergentes)?

10. En torno a la experimentación, ensayo y error, nuevos formatos y contenidos ¿cómo se asumen estos elementos en cada una de estas categorías de producción audiovisual: tradicional y de youtuber?

11. De acuerdo a sus experiencias y análisis ¿cuáles son las semejanzas y diferencias en cuanto a técnicas audiovisuales que usan con mayor regularidad los youtubers y los empleados por los productores tradicionales?

12. ¿Qué cambios aprecia usted en la lógica económica (comercial) de la producción audiovisual de los youtubers respecto a la producción audiovisual tradicional?

13. ¿Qué otros aspectos considera usted están marcando diferencias entre ambos tipos de producción audiovisual: tradicional y de youtubers? 


\section{ANEXO 2: Matriz de análisis de contenido}

\begin{tabular}{|c|c|c|c|c|c|c|c|c|c|}
\hline $\mathbf{N}$ & $\begin{array}{l}\text { Nombre y } \\
\text { apellido }\end{array}$ & Fuente & Tipo de estudio & Año & País & Título & Categoría & Subcategoría & $\begin{array}{c}\text { Fuente } \\
\text { Excluida/Incluida }\end{array}$ \\
\hline 1 & $\begin{array}{l}\text { Almaraz, I, } \\
\text { González, } \\
\text { M., y Ors, C. }\end{array}$ & Dialnet & $\begin{array}{l}\text { Análisis de } \\
\text { contenido. }\end{array}$ & 2013 & España & $\begin{array}{l}\text { Análisis de los mensajes audiovisuales } \\
\text { del Tercer Sector en YouTube. }\end{array}$ & $\begin{array}{l}\text { Producción } \\
\text { audiovisual }\end{array}$ & $\begin{array}{l}\text { Mensajes } \\
\text { audiovisuales }\end{array}$ & Incluida \\
\hline 2 & Antolín, R. & $\begin{array}{l}\text { Google } \\
\text { Académico }\end{array}$ & $\begin{array}{l}\text { Análisis de } \\
\text { contenido. }\end{array}$ & 2012 & España & $\begin{array}{l}\text { YouTube como paradigma del vídeo y } \\
\text { la televisión en la web } 2.0\end{array}$ & No aplica & No aplica & Excluida \\
\hline 3 & Losada, I. & $\begin{array}{l}\text { Google } \\
\text { Académico }\end{array}$ & Estudio de caso. & 2016 & España & $\begin{array}{l}\text { Poder audiovisual: YouTube como } \\
\text { aliado de los medios de comunicación } \\
\text { tradicionales en España para la difusión } \\
\text { de contenido. }\end{array}$ & $\begin{array}{l}\text { Producción } \\
\text { audiovisual }\end{array}$ & $\begin{array}{l}\text { Mensajes } \\
\text { audiovisuales }\end{array}$ & Incluida \\
\hline 4 & $\begin{array}{l}\text { Sabich, M. y } \\
\text { Steinberg, L. }\end{array}$ & $\begin{array}{l}\text { Google } \\
\text { Académico }\end{array}$ & Artículo original. & 2017 & Argentina & $\begin{array}{l}\text { Discursividad youtuber: afecto, } \\
\text { narrativas y estrategias de socialización } \\
\text { en comunidades de Internet. }\end{array}$ & No aplica & No aplica & Excluida \\
\hline 5 & $\begin{array}{l}\text { Montesinos, } \\
\text { I. }\end{array}$ & $\begin{array}{l}\text { Google } \\
\text { Académico }\end{array}$ & $\begin{array}{l}\text { Cuantitativo con } \\
\text { diseño de } \\
\text { investigación } \\
\text { cuasiexperimental. }\end{array}$ & 2014 & Ecuador & $\begin{array}{l}\text { Youtube como recurso audiovisual para } \\
\text { el desarrollo de la comunicación oral } \\
\text { del idioma Inglés en estudiantes del } \\
\text { 2do de bachillerato de la especialidad } \\
\text { Secretariado Bilingüe del Instituto } \\
\text { Tecnológico Superior Gran Colombia, } \\
\text { período lectivo 2012-2013. }\end{array}$ & $\begin{array}{l}\text { Producción } \\
\text { audiovisual }\end{array}$ & $\begin{array}{l}\text { Mensajes } \\
\text { audiovisuales }\end{array}$ & Incluida \\
\hline 6 & Aguilar, J. & $\begin{array}{l}\text { Google } \\
\text { Académico }\end{array}$ & $\begin{array}{l}\text { Diseño } \\
\text { bibliográfico de } \\
\text { tipo documental. }\end{array}$ & 2018 & Ecuador & $\begin{array}{l}\text { YouTube como herramienta para la } \\
\text { construcción de la sociedad del } \\
\text { conocimiento }\end{array}$ & No aplica & No aplica & Excluida \\
\hline 7 & López, A. & Dialnet & Artículo original. & 2016 & Argentina & $\begin{array}{l}\text { Youtubers. Nueva lógica comercial y } \\
\text { narrativa en la producción de } \\
\text { contenidos para la web. }\end{array}$ & $\begin{array}{l}\text { Producción } \\
\text { audiovisual }\end{array}$ & $\begin{array}{l}\text { Narrativa } \\
\text { audiovisual }\end{array}$ & Incluida \\
\hline 8 & Tórtola, A. & $\begin{array}{l}\text { Google } \\
\text { Académico }\end{array}$ & $\begin{array}{l}\text { Análisis de } \\
\text { contenido. }\end{array}$ & 2017 & Argentina & $\begin{array}{l}\text { La televisión en la era de las nuevas } \\
\text { tecnologías. }\end{array}$ & No aplica & No aplica & Excluida \\
\hline 9 & Alonso, R. & $\begin{array}{l}\text { Google } \\
\text { Académico }\end{array}$ & Artículo original. & 2002 & España & $\begin{array}{l}\text { La influencia de las nuevas tecnologías } \\
\text { en la cultura audiovisual } \\
\text { contemporánea. }\end{array}$ & $\begin{array}{l}\text { Producción } \\
\text { audiovisual }\end{array}$ & $\begin{array}{l}\text { Lenguaje } \\
\text { audiovisual }\end{array}$ & Incluida \\
\hline
\end{tabular}




\begin{tabular}{|c|c|c|c|c|c|c|c|c|c|}
\hline 10 & $\begin{array}{l}\text { Hidalgo, T, } \\
\text { y Segarra, J. }\end{array}$ & $\begin{array}{l}\text { Google } \\
\text { Académico }\end{array}$ & $\begin{array}{l}\text { Análisis de } \\
\text { contenido. }\end{array}$ & 2017 & España & $\begin{array}{l}\text { El fenómeno youtuber y su expansión } \\
\text { transmedia. Análisis del } \\
\text { empoderamiento juvenil en redes } \\
\text { sociales. }\end{array}$ & Youtubers & Juvenil & Incluida \\
\hline 11 & Gómez, N. & $\begin{array}{l}\text { Google } \\
\text { Académico }\end{array}$ & $\begin{array}{l}\text { Análisis de } \\
\text { contenido. }\end{array}$ & 2014 & España & $\begin{array}{l}\text { Youtubers: fenómeno de la } \\
\text { comunicación y vehículo de } \\
\text { transmisión cultural para la } \\
\text { construcción de identidad adolescente. }\end{array}$ & Youtubers & Juvenil & Incluida \\
\hline 12 & $\begin{array}{l}\text { De Oliveira, } \\
\text { M. }\end{array}$ & $\begin{array}{l}\text { Google } \\
\text { Académico }\end{array}$ & Artículo original. & 2017 & Brasil & $\begin{array}{l}\text { Derecho a la comunicación en } \\
\text { YouTube: perspectivas teóricas en las } \\
\text { encuestas de Intercom. }\end{array}$ & No aplica & No aplica & Excluida \\
\hline 13 & Collarte, E. & $\begin{array}{l}\text { Google } \\
\text { Académico }\end{array}$ & Multimodal & 2009 & Chile & $\begin{array}{l}\text { Los jóvenes y su visión de mundo. } \\
\text { Producción y publicación de videos en } \\
\text { Youtube. }\end{array}$ & Youtubers & Juvenil & Incluida \\
\hline 14 & Gómez, O. & $\begin{array}{l}\text { Google } \\
\text { Académico }\end{array}$ & $\begin{array}{l}\text { Análisis de } \\
\text { contenido. }\end{array}$ & 2018 & España & $\begin{array}{l}\text { Análisis de la narrativa audiovisual de } \\
\text { los Youtubers y su impacto en los } \\
\text { jóvenes colombianos. }\end{array}$ & $\begin{array}{l}\text { Producción } \\
\text { audiovisual }\end{array}$ & $\begin{array}{l}\text { Narrativa } \\
\text { audiovisual }\end{array}$ & Incluida \\
\hline 15 & Jódar, J. & Redalyc & Artículo original. & 2010 & México & $\begin{array}{l}\text { La era digital: nuevos medios, nuevos } \\
\text { usuarios y nuevos profesionales. }\end{array}$ & No aplica & No aplica & Incluida \\
\hline 16 & $\begin{array}{l}\text { González, E, } \\
\text { y Chica, D. }\end{array}$ & Scielo & Multimodal. & 2018 & Ecuador & $\begin{array}{l}\text { Conducta de los suscriptores en } \\
\text { YouTube: estudio de caso del canal } \\
\text { EnchufeTv. }\end{array}$ & No aplica & No aplica & Excluida \\
\hline 17 & $\begin{array}{l}\text { Rufí, J. y } \\
\text { Pérez, F. }\end{array}$ & $\begin{array}{l}\text { Google } \\
\text { Académico }\end{array}$ & $\begin{array}{l}\text { Análisis de } \\
\text { contenido. }\end{array}$ & 2013 & España & $\begin{array}{l}\text { Nuevos formatos audiovisuales en } \\
\text { Internet: cuando el usuario es quien } \\
\text { innova. }\end{array}$ & $\begin{array}{l}\text { Producción } \\
\text { audiovisual }\end{array}$ & $\begin{array}{l}\text { Mensajes } \\
\text { audiovisuales }\end{array}$ & Incluida \\
\hline 18 & Braga, J. & \begin{tabular}{|l} 
Google \\
Académico
\end{tabular} & $\begin{array}{l}\text { Análisis de } \\
\text { contenido. }\end{array}$ & 2011 & Brasil & Dispositivos interactivos. & No aplica & No aplica & Excluida \\
\hline 19 & $\begin{array}{l}\text { Márquez, I., } \\
\text { y Ardévol, } \\
\text { E. }\end{array}$ & $\begin{array}{l}\text { Google } \\
\text { Académico }\end{array}$ & Artículo original. & 2018 & España & $\begin{array}{l}\text { Hegemonía y contrahegemonía en el } \\
\text { fenómeno youtuber. }\end{array}$ & No aplica & No aplica & Excluida \\
\hline 20 & $\begin{array}{l}\text { Onaindia, J., } \\
\text { y Madedo, } \\
\text { F. }\end{array}$ & Researchgate & Artículo original. & 2013 & Argentina & La industria audiovisual. & $\begin{array}{l}\text { Producción } \\
\text { audiovisual }\end{array}$ & $\begin{array}{l}\text { Narrativa } \\
\text { audiovisual }\end{array}$ & Incluida \\
\hline 21 & Rodríguez, I. & $\begin{array}{l}\text { Google } \\
\text { Académico }\end{array}$ & Multimodal. & 2017 & España & $\begin{array}{l}\text { Marketing experiencial con } \\
\text { influencers: los nuevos impulsores de } \\
\text { la industria cinematográfica. }\end{array}$ & No aplica & No aplica & Excluida \\
\hline
\end{tabular}




\begin{tabular}{|c|c|c|c|c|c|c|c|c|c|}
\hline 22 & Roger, V. & $\begin{array}{l}\text { Google } \\
\text { Académico }\end{array}$ & $\begin{array}{l}\text { Análisis de } \\
\text { contenido. }\end{array}$ & 2010 & España & $\begin{array}{l}\text { Nuevas tecnologías aplicadas a la } \\
\text { realización de la información } \\
\text { audiovisual y retransmisiones } \\
\text { deportivas. }\end{array}$ & Youtubers & Deporte & Incluida \\
\hline 23 & León, L. & $\begin{array}{l}\text { Google } \\
\text { Académico }\end{array}$ & Artículo original. & 2018 & Perú & $\begin{array}{l}\text { Niños youtubers y el proceso de } \\
\text { creación de videos: evidencia de } \\
\text { competencias transmedia en acción. }\end{array}$ & Youtubers & Infantil & Incluida \\
\hline 24 & Sora, C. & Researchgate & Artículo original. & 2015 & España & $\begin{array}{l}\text { Etapas, factores de transformación y } \\
\text { modelo de análisis del nuevo } \\
\text { audiovisual interactivo online. }\end{array}$ & $\begin{array}{l}\text { Producción } \\
\text { audiovisual }\end{array}$ & $\begin{array}{l}\text { Narrativa } \\
\text { audiovosual }\end{array}$ & Incluida \\
\hline 25 & $\begin{array}{l}\text { Lloret, N. y } \\
\text { Canet, F. }\end{array}$ & $\begin{array}{l}\text { Google } \\
\text { Académico }\end{array}$ & Artículo original. & 2008 & España & $\begin{array}{l}\text { Nuevos escenarios, nuevas formas de } \\
\text { expresión narrativa: La Web } 2.0 \text { y el } \\
\text { lenguaje audiovisual. }\end{array}$ & $\begin{array}{l}\text { Producción } \\
\text { audiovisual }\end{array}$ & $\begin{array}{l}\text { Lenguaje } \\
\text { audiovisual }\end{array}$ & Incluida \\
\hline 26 & $\begin{array}{l}\text { Gallardo, J., } \\
\text { y Jorge, A. }\end{array}$ & $\begin{array}{l}\text { Google } \\
\text { Académico }\end{array}$ & $\begin{array}{l}\text { Análisis de } \\
\text { contenido. }\end{array}$ & 2010 & España & $\begin{array}{l}\text { La baja interacción del espectador de } \\
\text { vídeos en Internet: caso Youtube } \\
\text { España }\end{array}$ & No aplica & No aplica & Excluida \\
\hline 27 & $\begin{array}{l}\text { Guzmán, A, } \\
\text { y Moral, M. }\end{array}$ & Scielo & Multimodal. & 2014 & Portugal & $\begin{array}{l}\text { Tendencias de uso de YouTube: } \\
\text { optimizando la comunicación } \\
\text { estratégica de las universidades } \\
\text { iberoamericanas }\end{array}$ & No aplica & No aplica & Excluida \\
\hline
\end{tabular}


Anexo 3: Artículos según criterio de análisis

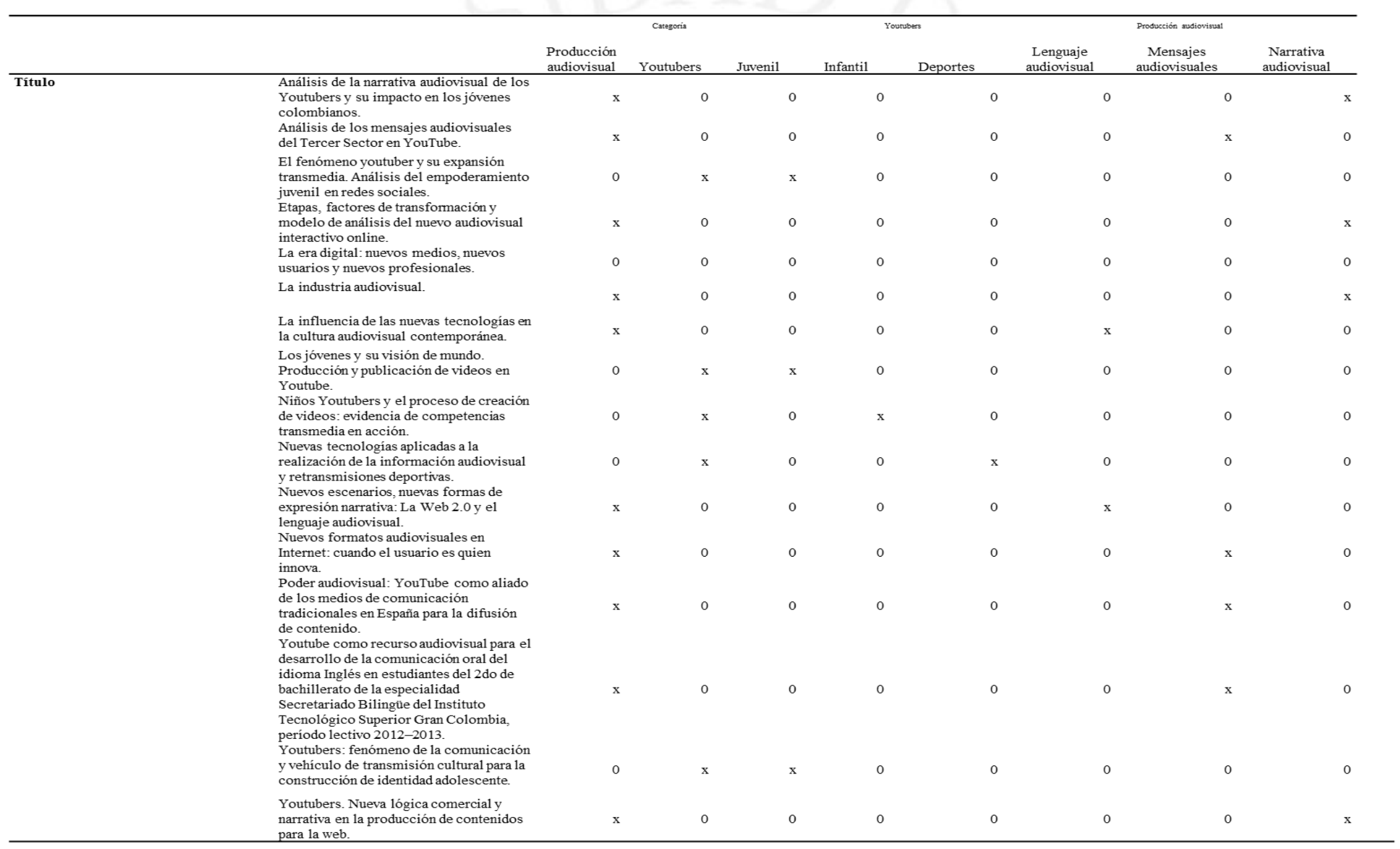




\section{ANEXO 4: Entrevista a Productor Audiovisual}

\section{ENTREVISTA PRODUCTOR CÉSAR ARANA}

\section{¿Que implica el sistema de producción tradicional y su diferenciación con el sistema de producción de los youtubers?}

Tienes que partir de varias cosas. Tienes que partir del tipo de contenido que estés trabajando, del tipo de proyecto que quieras trabajar; tienes que partir un poco del género y del formato que te interese abarcar. Tienes que partir conociendo muy bien a tu público, el público al cual quieres llegar. Deberías tomar en cuenta una investigación sobre el tema que vas a abordar, que vas a tocar; mientras mejor conozcas a tu público, mejor conozcas el tema, vas a manejar muchas y mejores variables. Tienes que tomar en cuenta en qué tipo de plataforma vas a emitir tu contenido. Es a partir de esas variables que tienes que definir, en primer lugar, el decir tipo de público, tipo de plataforma, tipo de contenido. El proceso de producción tradicional pasa por diferentes etapas claramente diferenciadas. Tienes una primera etapa de investigación y de preparación del proyecto, una segunda etapa de preproducción del proyecto, tienes una tercera etapa de producción y realización en sí y tienes una última etapa de postproducción y, dependiendo del tipo de proyecto que hayas abordado, tienes una cuarta etapa en la cual te dedicas a ver temas de promoción, distribución y lanzamiento. Por lo poco que sé acerca de la forma de producir de los youtubers, yo no creo que estén respetando mucho ese proceso.

\section{¿Entonces los youtubers son más espontáneos?}

Yo creo que, en esa área, como lo mencionas, estamos hablando de un proceso de producción mucho más espontáneo e informal, algo más inmediato. Cuando tú trabajas bajo un método de producción tradicional, en la etapa de investigación, tienes que tratar de conocer a tu público, tu plataforma, el tipo de contenido. Si estuvieras trabajando un proyecto de ficción, tienes que ver el tema del guion, buscar rostros que interpreten a tus personajes y, si no es ficción, también tienes que pensar en rostros, en quiénes van a ser la imagen. En la etapa de preproducción tienes que preparar todo lo que vayas a necesitar 
para la etapa de realización; tienes que elaborar un cronograma de trabajo, tienes que escoger a tu equipo, tienes que pensar o saber qué recursos vas a tener, con qué recursos vas a contar a nivel técnico, a nivel de dinero, a nivel de personal, tiene que estar todo completamente detallado, planificado, estructurado. En la etapa de realización, tienes que tratar de cumplir con todo lo establecido en la etapa de preproducción; no puedes exceder tiempos, no puedes excederte de presupuestos, tienes que mantener un nivel de la producción y en la etapa de post producción igual tienes que cumplir con plazos. El sistema de los youtubers creo que debe estar manejado de una manera mucho más aleatoria, mucho más informal como te venía diciendo. No sé qué tanto grado de planificación, de preparación puedan estar manejando ahí, pero bajo un sistema de producción formal debes tener en cuenta los pasos que te he mencionado.

\section{Dentro de su experiencia propia en lo que son producciones nacionales, ¿cree que el público tiene más aceptación hacia las producciones de los youtubers que a las producciones nacionales tradicionales?}

Depende de qué tipo de público hablamos. Si hablamos de un público adulto, o sea de alguien que tiene una experiencia más duradera con plataformas tradicionales como lo es el cine y la televisión, definitivamente sí se va a ir por lo tradicional. En cambio, el contenido de los youtubers te habla de un público joven, un público millenial, un público juvenil, el cual es un público que no está dispuesto a consumir información mediante los medios tradicionales y en ese sentido básicamente los contenidos que hacen estas personas que han aparecido en los últimos años está dirigido a ellos.

\section{¿Cómo percibe el proceso de retroalimentación que hay en las producciones} tradicionales?

Bueno, y, dependiendo del proyecto que estés trabajando, es muy importante que midas la respuesta de tu público; eso te va a decir de alguna manera si tu propuesta está funcionando, si tu contenido está funcionando $\mathrm{y}$, de acuerdo a eso, tienes que hacer ajustes, cambios y modificaciones. En el caso de los youtubers, también considero que es importante tener una retroalimentación; saber qué variables tendrán ellos, pues el número de vistas, el número de likes, que es para ellos lo que en la producción tradicional es el rating y la audiencia, mientras más seguidores tengan, tendrán en claro que lo que están 
haciendo, produciendo, está funcionando, de alguna manera pensando en el público al cual se están dirigiendo.

\section{¿En el plano económico los youtubers manejarían un presupuesto algo reducido comparado a las producciones tradicionales?}

Claro. Hay niveles de inversión completamente diferentes; en el sistema de producción tradicional te hablo de un mayor costo de producción a todo nivel: a nivel de inversión, personal, a nivel de recurso. Lo que es la producción para plataformas digitales como los youtubers, manejan otro nivel de inversión, ya que estamos hablando de un tipo de contenido totalmente diferente que maneja otras variables. Un youtuber puede generar su contenido propio, él mismo, sin necesidad de un equipo que trabaje con él. Estamos hablando de variables de producción completamente distintas, completamente diferentes; eso ha permitido que se abaraten costos, que se popularice, se democratice un poco el contenido para plataformas digitales. Ellos pueden producir su contenido desde un celular sin inconvenientes. Entonces son formas de producir completamente distintas.

\section{¿Usted cree que con el tiempo YouTube se volverá el principal medio de} información?

Yo no sé si termine siendo la principal plataforma de información. Yo creo que, en lo que respecta a información, siempre va a haber una necesidad por parte del público de recurrir a una fuente confiable. Ha pasado y ha ocurrido muchas veces que las plataformas digitales no son muy confiables; o sea, tú no sabes hasta qué punto lo que están diciendo o están poniendo, si hablamos de información, es $100 \%$ segura. Siempre el público va a pretender recurrir a una plataforma oficial tradicional para confirmar si eso que está viendo en Facebook, Instagram o cualquier otra plataforma digital es realmente cierto o no. Entonces, siempre ambas van a tener un espacio y, de hecho, están cambiando las formas de consumir; se están definiendo nuevos públicos, se están definiendo nuevas formas de producir contenido. Yo creo que estamos dentro de un proceso que está terminando de definirse. 


\title{
ANEXO 5: Entrevista a Especialista en Producción Audiovisual
}

\author{
ENTREVISTA PROFESOR SUBAUSTE. ANALISTA DE CONTENIDOS \\ DIGITALES
}

\section{En los medios tradicionales tenemos el pre, la producción y la post. ¿En los medios digitales también se pasa por ese proceso?}

No ha cambiado el concepto de producción en los streaming o medios digitales; lo que ha cambiado es la dinámica y la facilidad de reaccionar y tomar decisiones. Lo que tú encuentras cuando analizas el sistema de producción de los youtubers más reconocidos es que finalmente también efectúan un proceso similar, porque esto tiene que ver con la capacidad de planificar; cuando tú planificas mínimamente, tienes la capacidad de prever resultados y de ajustar productos deseados en su versión final. Algunos de los youtubers más conocidos, de hecho, tú te das cuenta que hay la concepción de un tema, el diseño de una estructura y que, a partir de ahí, ellos desarrollan una propuesta ante cámaras que incluso luego editan regularmente; aunque también está el otro caso, de que sea una transmisión en vivo, donde también puedes tener una pauta previa que te permite lanzarte en directo y hacer un live streaming, donde ya no necesitas de la producción y esto sale tal cual. Si nosotros hablamos de eso, podríamos hablar de otra tendencia que implica un emisor más empírico, que produce y que crea contenido conforme se enfrenta al medio. Entonces, improvisa el manejo de contenidos, porque está en función del instante, del momento y esta capacidad no implica necesariamente tener una planificación en la lógica de lo convencional (pre producción, producción). El vivo del digital lo que ha modificado es justamente la facilidad, el acceso y la velocidad con la que tú puedes crear y producir contenido, frente a lo que significaba producir en vivo por el medio tradicional, que demandaba fundamentalmente, por esas condiciones, una configuración de personal, equipo e infraestructura para sacar al aire una producción de esa naturaleza. El digital rompe todos los esquemas. 
En términos de interacción con el público, ¿no cree usted que los medios digitales tienen mucha más interacción con el público que la que pueden tener los medios tradicionales?

Por supuesto. Eso es inherente, ya que es la principal característica del medio digital. La interactividad es lo primero que marcó la diferencia con los medios tradicionales; la cuestión de la emisión en vivo ha sido un proceso posterior, pero, para comenzar, el hecho de que tú pudieras conectarte en directo a través de solo texto, significó gradualmente la aparición del chat como un mecanismo de comunicación inmediato, que cambió y transformó la lógica de otros medios de comunicación. Ya hablando específicamente de mecanismos de contacto, no nos podemos olvidar, y esto probablemente la gente más joven no lo sabe, pero los orígenes, aparece el teléfono celular y el teléfono celular se digitaliza y comienza a ofrecer una serie de prestaciones adicionales. Ya el hecho de que apareciera la telefonía celular comenzó a marcar un poco esa entrada como fórmula de interacción. La digitalización de este dispositivo igualmente fue superada cuando aparecen en medios digitales las primeras redes sociales. El Messenger, creado por Hotmail, que fue toda una transformación, porque implicó la posibilidad de ir gradualmente cambiando los comportamientos de la forma de interacción y de contacto del público y, luego de eso, una serie de servicios se vieron afectados y terminaron desapareciendo. A eso tenemos que sumarle que probablemente se dice que fue iPhone, pero Apple, a partir de la configuración ya de una tecnología digital a través de un dispositivo móvil de la telefonía inteligente, ahí es donde se marca otro hito en el gran cambio de lo que significa esta fórmula de interacción y de transformación de los contenidos frente a los medios convencionales, a tal punto que los medios convencionales no saben bien cómo hacerlo, pero tienen que ver la manera de cómo integrar día a día mecanismos digitales para los contenidos que producen.

\section{¿En el punto económico donde se ve que hay mayor inversión en los medios digitales o tradicionales?}

Los medios convencionales siguen demandando inversiones muy altas en el tema de equipos, infraestructura y de acceso a los mecanismos de distribución y difusión de estos contenidos; mientras que lo digital siempre, desde un principio, ha abaratado costos. 
Entonces, la diferencia marcada es en lo que es el tema económico para una producción más trabajada.

\section{¿Son más profesionales los medios tradicionales que los medios digitales?}

No es que sean más profesionales, sino que los medios digitales son una experiencia más empírica para el que la realiza. Siempre su contenido va a ser algo espontaneo y basado en la experiencia, y eso va a depender del uso que le dé al dispositivo que tiene para grabar el contenido en el momento exacto.

\section{¿Qué opina del tema de los auspicios en los medios digitales?}

Eso ha cambiado muchísimo, y sobre todo en los últimos años, ya que la penetración de estos mecanismos, como redes sociales y medios digitales, ha hecho despertar a las marcas y a las empresas interesadas en llegar a un nuevo público, y eso ha derivado en que se ha convertido y se ha reconfigurado el mercado de los anuncios. A las marcas siempre les va a convenir hacer tratos con un nuevo público, como es el que tienen los youtubers, que es un público joven.

\section{¿Cree usted que los medios digitales sean el principal medio de acceso a la información?}

Creo que tarde o temprano esto va a ocurrir, porque ya estamos en esta lógica. Ya se ve en varias investigaciones un gran consumo de medios digitales en comparación de los tradicionales; gran parte de los estudios que hay sobre los medios convencionales indican que hay un descenso notable en lo que es el servicio de información y entretenimiento, debido a los medios digitales. La televisión y los medios convencionales no tienen respuesta hacia el boom de los medios digitales y tienen que buscar adaptarse y digitalizar sus servicios, e incluso los vemos en las aplicaciones que han lanzado para ver una programación vía Internet y ya no por tv. Con el pasar de los años, los usos y costumbres van a cambiar y los millenials van a estar en la cabeza, y ellos son los principales usuarios de medios digitales. Ya hoy en día es raro ver a alguien escuchando radio o viendo televisión. Es más común ver a gente pegada a una Tablet o a su teléfono celular. 


\section{ANEXO 6: Guía de entrevista a youtuber}

1. ¿Consideras que hay diferencias entre la televisión y YouTube? ¿Cuáles crees que son las principales diferencias?

2. ¿Consideras a YouTube un medio emergente? ¿Por qué?

3. ¿De qué manera crees que han impactado los youtubers en el público en general, respecto a los medios tradicionales?

4. Para comunicar tus ideas y proyectos, ¿qué plataformas digitales utilizas y cómo las utilizas?

5. ¿Qué sensaciones o emociones buscas generar en tu público objetivo?

6. ¿Es posible para un youtuber profesionalizarse en su trabajo, tanto en lo económico como en los aspectos técnicos, sin correr el riesgo de perder lo que atrae a su público de este medio?

7. Ahora cerremos con unas preguntas más personales. ¿Por qué decidiste ser youtuber?

8. ¿Te consideras un influencer? ¿Cuál es la diferencia entre un influencer y un youtuber?

9. ¿Cuáles son tus referentes en YouTube, tanto a nivel nacional como internacional y por qué?

10. ¿Cómo crees que será el futuro de YouTube?

11. Finalmente, ¿puede detallar los siguientes aspectos de su producción?

a. Cámara(s) usada(s).

b. Equipo de iluminación.

c. Equipo de audio.

d. Programas de edición utilizados.

e. Recursos de terceros.

f. Fases de producción que aplica y cómo. 


\section{ANEXO 7: Entrevista a youtuber}

\section{ENTREVISTA A YOUTUBER VICHO}

1. ¿Consideras que hay diferencias entre la televisión y YouTube? ¿Cuáles crees que son las principales diferencias?

Sí existen diferencias, en cuanto a interacción medio-viewer, la evaluación de métricas es más exacta que en la tv, la elección de a qué hora, y cuando ver un video de YouTube, frente a los horarios fijos de la tv. El Youtuber no está necesariamente presionado por el auspiciador, por lo que tiene mayor libertad de acción.

2. ¿Consideras a YouTube un medio emergente? ¿Por qué?

Entre emergente y a ser parte de los medios tradicionales de comunicación. Los medios tradicionales, ya están considerando a Youtube como medio de información, incluso están empezando a interactuar con él, tal es el caso de Andysane y Latina Tv.

3. ¿De qué manera crees que han impactado los youtubers en el público en general, respecto a los medios tradicionales?

La torta está inclinándose a favor de Youtube. Pero los medios tradicionales siguen teniendo mayor credibilidad.

4. Para comunicar tus ideas y proyectos, ¿qué plataformas digitales utilizas y cómo las utilizas?

Youtube para mis videos e Instagram.

5. ¿Qué sensaciones o emociones buscas generar en tu público objetivo?

Risa, en algunos casos indignación. 
6. ¿Es posible para un youtuber profesionalizarse en su trabajo, tanto en lo económico como en los aspectos técnicos, sin correr el riesgo de perder lo que atrae a su público de este medio?

Claro que sí, siempre y cuando no pierda el sentido de su contenido.

7. Ahora cerremos con unas preguntas más personales. ¿Por qué decidiste ser youtuber?

Porque mi cabeza es un amasijo de ideas que necesitan salir

8. ¿Te consideras un influencer? ¿Cuál es la diferencia entre un influencer y un youtuber?

Todos somos influencers. Un youtuber simplemente es una persona que tiene un canal de Youtube. Pero si la persona por sí misma, no llega a persuadirte para algo en específico, entonces no es influencer. Ejemplo: un canal de YouTube que muestra a su perro comiendo, sin contexto alguno y sin ningún fin.

9. ¿Cuáles son tus referentes en YouTube, tanto a nivel nacional como internacional y por qué?

Nigahiga, porque es chévere, lo he visto desde sus inicios cuando no tenía nada, era pura creatividad y he sido testigo de cómo fue creciendo.

10. ¿Cómo crees que será el futuro de YouTube?

Crecerá o será comprado por otra empresa, con internet todo es incierto.

11. Finalmente, ¿puede detallar los siguientes aspectos de su producción?

a. Cámara(s) usada(s): Canon t5i

b. Equipo de iluminación.: Luz natural

c. Equipo de audio. Saramonic shotgun mic

d. Programas de edición utilizados.: Premier, photoshop y audition

e. Recursos de terceros: Stock de youtube, pexels, e imagenes de google.

f. Fases de producción: https://www.youtube.com/watch?v=ODXg2cmm60s 


\section{ANEXO 8: Entrevista a youtuber}

\section{ENTREVISTA A YOUTUBER KARINA ARANCIBIA}

1. ¿Consideras que hay diferencias entre la televisión y YouTube? ¿Cuáles crees que son las principales diferencias?

En YouTube, tu entras directamente a lo que quieres elegir, ósea tú buscas de frente, no estas esperando como en la televisión a que llegue la información si no que, aquí tienes el link de libre acceso para buscar directamente lo que necesitas, sin necesidad de establecer un horario o saltándote de ver contenidos extras.

Pero también, está la contraparte de que en YouTube para que llegues a un canal o información específica por encima te van a salir opciones que no son de tu país u otros contenidos distintos y tienes que darte tiempo para llegar a la información que finalmente vas a utilizar.

Una vez que llegas a un tema te lleva a temas relacionados de tu interés y es algo que te sirve para que el tiempo de búsqueda sea menor.

2. ¿Consideras a YouTube un medio emergente? ¿Por qué?

Considero que ha sido un medio emergente, pero hoy en día ya está establecido porque ya la gente que entra a YouTube es gente que ya sabe específicamente lo que ha ido a buscar, años atrás, en el 2007 cuando yo estaba en el colegio, YouTube recién comenzaba incluso el contenido que había antes, era completamente distinto, ahora se genera contenido para cada uno de los géneros que se necesite, historia, pastelería, viajes, gamers, hay más variedad y eso es lo que lo ha convertido en medio emergente, porque siempre hay gente que quiere contar algo y nunca habían tenido una plataforma que les permita llegar a todos, sin necesidad de un casting como lo es en la televisión, ahora todos pueden comunicar algo y si es de valor se vuelve de interés hacía los demás.

3. ¿De qué manera crees que han impactado los youtubers en el público en general, respecto a los medios tradicionales? 
Han generado fidelidad con sus seguidores, porque finalmente les están dando contenido de calidad, si tú ves digamos a escalas de años anteriores a ahora, incluso los mismos youtubers han ido evolucionando sus canales, han ido agregándoles más contenido, el tema de edición ha sido mucho más pulido, porque si tú ves en retrospectiva antes lo hacían en escenarios más simples, ahora ponen escenarios más sofisticados y te dan opciones para ofrecer diferentes estilos eso en el modo audio visual.

Esto se da a medida de las respuestas que tienes de tu público y eso hace que tú mismo te retes a mejorar, es como en cualquier otro trabajo, si tú no vas mejorando tus estándares de calidad, a la larga la gente lo va a dejar de ver, es igualito a lo que pasa en la tv, si tú no vas modificando los programas a largo plazo la gente se satura y deja de verlos.

A diferencia de un programa de tv, YouTube, te permite tener mucha más cercanía con el público que te está viendo, te permite por ejemplo en mi caso que yo hago recetas te permite que abajo la gente comente preguntándote sobre esa receta o si les ha quedado alguna duda cosa que en la tv no se puede hacer, porque a veces para llegar al personaje que está detrás de la tv es como que no te permite tener esa cercanía y es lo que hay y se acabó, en cambio lo que se ha creado a través del YouTube son comunidades donde el creador de contenido tiene mucha más cercanía y acceso a poder conversar con sus seguidores o su público objetivo hasta cierto punto, que eso a parte ya se viene reforzando a través de otras redes sociales que vas involucrando además de YouTube ósea para tener un canal de comunicación mucho más directo o también la plataforma que ahora tiene YouTube que tú puedes lanzar el video inbox y durante el lanzamiento del video tú estás conectado y puedes ir respondiéndoles las dudas a las personas que están ahí.

4. Para comunicar tus ideas y proyectos, ¿qué plataformas digitales utilizas y cómo las utilizas?

Yo utilizo YouTube para hacer videos de recetas, Instagram y Facebook para poder comunicarme y como medio de venta.

Cuando empecé con YouTube, ósea hace años yo quería hacerlo, pero no sé, me daba vergüenza de repente, o decía de repente el contenido que voy a hacer no le va a interesar a la gente, que se yo, pero hasta que un día dije, ok, lo voy a probar y vamos a ver qué tal me va y tuve muy buena respuesta, lo que hago para complementar porque obviamente al entrar a YouTube es un terreno nuevo para mí, porque YouTube funciona o sea la 
manera cómo funciona YouTube sobre cómo obtener seguidores es muy distinta a la de Facebook o Instagram, porque en YouTube tú tienes que realmente generar un gran interés con tu suscriptor para que el apriete el botoncito , no es como el otro, que pones me gusta, no me gusta, te sigo o no, si no que en YouTube, para que tú puedas generar una empatía con tu suscriptor él tiene que ver unos 4 o 5 vídeos de su interés para decidirse a poner el clic en la ventanita de suscribir, ahora como hago yo, para complementar eso porque obviamente YouTube es el medio menos conocido para mí, es que empecé a través de las redes sociales tipo Facebook o Instagram a hacer rondas de preguntas sobre que vídeos quieren que coloqué en YouTube, ósea involucro a todas las redes sociales, por ejemplo hago la ronda de preguntas a través de Instagram, donde aprovecho para contestar dudas a la gente, que va viendo los videos sobre las recetas o que de repente quieran empezar a hacer un negocio y no saben cómo hacerlo, yo trato de responderles por ahí, de todos los pedidos, lo que ellos quieren, es que les enseñe como hacer la cotización de un producto para no perder plata, para ganar. A través de Instagram, he tenido una temática para lanzarla en YouTube, al final todo está involucrado o, por ejemplo, cuando yo subo un vídeo en YouTube, dónde publico mi receta es en Facebook y en la cajita de descripción te pongo el vínculo que te lleva a mi vídeo en YouTube. Al final, uno todas las redes sociales, porque estoy generando una comunidad multiplataforma y eso es el medio por el que empecé a trabajar desde el año pasado, que arranque con lo del YouTube y que he tratado de mantener hasta ahora y de hecho me ha dado buenos resultados

5. ¿Qué sensaciones o emociones buscas generar en tu público objetivo?

Impulsarlos a que emprendan sus negocios, pero también enseñarles, a que pueden hacer pastelería o cocinar, sin que les sea algo difícil, normalmente cuando yo he visto algún tipo de video y es en lo que yo me he tratado de enfocar más, al haber trabajado en recetarios para diferentes revistas es que había miles de recetarios y miles de videos donde te dicen esto se hace de esta manera u otra, pero no te dan las pautas ni las cantidades necesarias y cuando el usuario lo realizaba, no le salía como debería salirle, entonces cuando empecé a escribir en revistas y una de mis políticas era revisar que todo lo que decían en las recetas estaban bien y si había algo mal que la arreglen y me la vuelvan a dar para poder dar la información correcta, de esa manera aprendía a leer recetas antes de que estudiar pastelería, eso me ha ayudado a tener una imagen de chef en línea generando 
que me pregunten cosas acerca de recetas y yo les respondo para que puedan realizar su cocina de la mejor manera.

6. ¿Es posible para un youtuber profesionalizarse en su trabajo, tanto en lo económico como en los aspectos técnicos, sin correr el riesgo de perder lo que atrae a su público de este medio?

Ahora la profesionalización no es tan necesaria, por el mismo avance de la tecnología y con el pasar del tiempo, está al alcance de todos, es por eso, que para comunicar o generar contenido, no necesitas tanto equipo ni producción como en la Tv.

7. Ahora cerremos con unas preguntas más personales. ¿Por qué decidiste ser youtuber?

Al principio, me daba vergüenza o pensaba que no iba a generar interés por lo que quiero comunicar, pero es cuestión de perder el miedo y soltarte, al final de cuentas si tú crees que tu contenido es de valor, va a servir y vas a tener seguidores, siempre y cuando hagas caso a lo que la gente pide y necesite de acuerdo a tu rubro

8. ¿Te consideras un influencer? ¿Cuál es la diferencia entre un influencer y un youtuber?

Creo que en el aspecto de pastelería sí, lo que pasa es que creo, que hay unas mediciones para tipos de influencers, como son los microinfluencers, que es algo mucho más puntual para un solo aspecto , una cantidad de seguidores más pequeña que es lo que yo considero que tengo ahorita , pero si considero que influyo de manera positiva en la gente que está viendo el producto que yo hago, porque a través de mi trabajo, ellos me están mandando mensajes y un montón de gente me ha escrito, para decir que empezaron a hacer su negocio de pastelería cuando empezaron a ver a mis videos o que los tips que les doy les han servido, otras personas me dicen, me compré la batidora que me recomendaste y bacán y al final, si te das cuenta que tienes un impacto positivo en la gente.

Influencer se le llama a la persona que ya bien sea youtuber o instagramer, impacta de manera positiva en los seguidores que tiene, pero hay niveles para nombrar influencers o microinfluencers, de acuerdo a las medidas que tienen las empresas de marketing.

Y estos grupos pequeños, los microinfluencers, tiene seguidores más fieles que los macros influencers. 
9. ¿Cuáles son tus referentes en YouTube, tanto a nivel nacional como internacional y por qué?

Bueno lo más loco, es que yo no sigo o no tengo referentes de canales de pastelería, pero lo que si hago es seguir estilos por ejemplo del canal, "Mis pastelitos", luego a veces me pongo a ver tutoriales de diferentes youtubers a nivel mundial.

Si tengo que darte un referente sería el de "Mis pastelitos" ya que da información importante, me gusta su estilo y si me voy a otros youtubers, sigo youtubers de lecturas, que recomiendan libros y hacen críticas y te resumen series y películas, en si sigo YouTube para relajarme.

10. ¿Cómo crees que será el futuro de YouTube?

Que se mantenga siendo una plataforma que le da libre acceso a la información a la gente, creo que YouTube hasta cierto punto, ha ayudado a que el mundo globalizado se haya podido converger en un solo sitio, ósea tienes acceso a mucha información de todo el mundo y de diferentes rubros y para mi es importante, que YouTube siga siendo una plataforma de acceso para todos y ahora existe el YouTube Premium y ahora puedes ver contenido sin publicidad y es algo bueno, pero tampoco estoy en contra de la publicidad porque entiendo que los youtubers, están monetizando sus contenidos y les pagan por ese trabajo.

YouTube va a seguir mejorando como lo ha hecho hasta ahora, que puedes editar videos y poner efectos y música y eso es bueno y muchas veces es gracias a la publicidad.

Que continúe teniendo esa facilidad para unir al mundo con diferentes temáticas y generando esa confianza de que vas a subir tu video de manera rápida y segura.

11. Finalmente, ¿puede detallar los siguientes aspectos de su producción?

a. Cámara(s) usada(s): Sony Alpha 5100.

b. Equipo de iluminación: Tengo 2 soft box de marca godox y 1 ring light.

c. Equipo de audio: Tengo micro pechero, uso el grabador de audio de mi Iphone XR.

d. Programas de edición utilizados: Uso Adobe Premier.

e. Recursos de terceros: música/imágenes/video de stock. Tengo editora de videos y Fotógrafo. Banco de música sin $\mathrm{CR}$ de youtube. 
f. Fases de producción: Cada mes planeo qué videos podrían ir para el canal y siempre tengo que conversar con las marcas previamente, para decirles si quieren participar en el video y cuál sería el costo por participar. Cuando es un video de una sola marca, toda la producción es pagada por el cliente y se hace un cronograma de cuándo se va a grabar a la tienda o cuándo se va a grabar el video con su ropa. Lo mismo para los videos de Instagram. Luego, viene la coordinación con la editora. Por ejemplo, si grabo en la tardenoche de un viernes, yo le estoy pasando los videos a más tardar el sábado y la idea es que ella lo tenga listo en un máximo de dos días. Yo antes editaba mis videos; algunos todavía los edito yo, como los video blogs, pero, por temas de tiempo, los videos que son elaborados se los envío a ella. Para eso le mando un pauteo. Yo no hago un guion o un pauteo, pero si lo hago al momento de revisar el video, donde le indico de qué minuto a qué minuto quiero que aparezca y qué tipo de cortes quiero que tenga. 


\section{ANEXO 9: Entrevista a youtuber}

\section{ENTREVISTA A YOUTUBER DANIELA ACOSTA}

1. ¿Consideras que hay diferencias entre la televisión y YouTube? ¿Cuáles crees que son las principales diferencias?

En YouTube tú tienes el control, vas a tu ritmo, no tienes que esperar una hora determinada para sentarte a ver algo, tú decides lo que quieras, ver al momento que tu desees ver y el contenido también lo eliges, de acuerdo a tus gustos, en cambio en la tv hay una plancha de contenido y tu tendrías que escoger en que momento verlo, aparte hoy en día, con toda la tecnología móvil, puedes verlo donde sea, no tienes que estar sentado frente a la tv.

2. ¿Consideras a YouTube un medio emergente? ¿Por qué?

Ya no sé si tan emergente, emergente fue unos años atrás, yo creo que hoy en día es una plataforma de contenido que está ya en una edad media, es decir no está en pañales, está empezando a desarrollarse con más potencia, ya hay youtubers con más de 30 millones de suscriptores, entonces creo que ya está bastante avanzado. No lo veo en auge y siento más bien que este camino a ser una plataforma gigante en entretenimiento.

3. ¿De qué manera crees que han impactado los youtubers en el público en general, respecto a los medios tradicionales?

El youtuber es un generador de contenido vs el celebrity o artista de tv que está en un contenido impuesto, al celebrity se le contrata para determinado contenido, determinada plancha de contenido, ya establecida, mientras que el youtuber, genera su propio contenido, entonces hay un valor agregado en eso, que es una persona como tú o como yo, que está generando un contenido para un público que piensa como él y que tiene los mismos gustos de él, entonces tiene más empatía. 
4. Para comunicar tus ideas y proyectos, ¿qué plataformas digitales utilizas y cómo las utilizas?

Básicamente Instagram es una de las redes más fuerte que tengo después de YouTube, Instagram Historias, me permite estar cerca de mis seguidores en el día a día, Facebook es una plataforma que sirve mucho más a las personas que tienen trabajo de oficina y tienen abierta esa red social en la computadora como distracción, pero más es una herramienta para compartir memes, información, pero ya no es tanto el target, mientras que Instagram ahorita, luego de YouTube es una de las redes más fuertes que tengo.

5. ¿Qué sensaciones o emociones buscas generar en tu público objetivo?

Lo que busco es que tengan la moda al alcance del bolsillo, la intención de mi canal, no solo es mostrar moda porque sí, 'por las tendencias o conseguir lo caro, ósea el primer grupo de influencers en el tema, estaba dedicado a mostrar marcas caras mientras que había un mercado desatendido y entonces como que dije, puedes vestirte igual de bien, puedes verte increíble pero, a bajo presupuesto, entonces creo que una de las cosas que busco es mostrar ofertas, mostrar cosas que la mayoría de personas puede tener y vestirse bien.

6. ¿Es posible para un youtuber profesionalizarse en su trabajo, tanto en lo económico como en los aspectos técnicos, sin correr el riesgo de perder lo que atrae a su público de este medio?

En lo económico, las brechas son grandes pero eso, no genera mucha diferencia, creo yo, en el gusto del consumidor, podríamos hablar de lo que tú me dices, los auspicios, en el caso de la tv lo que es auspiciado, es el programa , mientras que nosotros los youtubers como marcas personales, somos los que manejamos los auspicios, aparte, lo ideal es que trabajo con marcas en las que yo creo y que consumo y veo que es favorable para recomendar a mis seguidores mientras que en la tv, en la menciones, te imponen y haces publicidad a productos que no usas, sin saber realmente si son buenas o malas, en cambio, en mi caso, si bien es cierto, hay un intercambio de dinero si yo menciono o recomiendo una marca, es porque la uso la voy a usar y creo en ella. 
7. Ahora cerremos con unas preguntas más personales. ¿Por qué decidiste ser youtuber?

Hace muchísimos años, cuando estaba en la universidad, quería compartir mis conocimientos de maquillaje y en ese entonces, porque mis primeras publicaciones fueron sobre maquillajes y entonces, tener la cantidad de suscriptores era bastante para el momento de YouTube en ese entonces, de hecho, Yuya, que hoy tiene más de 3 millones de seguidores, en ese entonces tenía cinco mil, seis mil seguidores y era muchísimo para ese entonces. Entonces yo quise compartir mis conocimientos y mis espectadores empezaron siendo mis amigos; luego lo dejé y cuando lo retomé y lo que quería era seguir mostrando mis conocimientos y generando contenido. Quería compartir lo que yo hacía de una forma dinámica y alcanzar a las personas con ese tipo de conocimiento. Entonces no es que yo quise ser youtuber si no que quise compartir conocimientos y cosas que me gustaban para un grupo de chicas que tenían mis mismos gustos.

8. ¿Te consideras un influencer? ¿Cuál es la diferencia entre un influencer y un youtuber?

Un youtuber es un influencer, un influencer es una persona que está influyendo en lo demás con opiniones, consejos, recomendaciones con tips, etc. Siendo así, sí me considero influencer, porque con lo que yo hago estoy influyendo a las personas no solo en opinión si no en acción, lo que yo digo y recomiendo, lo compran y van a la marca y dicen vengo por Daniela y es por eso que me buscan y me auspician y es toda una cadena digamos digital-comercial, donde lo que está de por medio es mi recomendación, mi influencia y sí me considero influencer, y un youtuber también puede ser un influencer.

9. ¿Cuáles son tus referentes en YouTube, tanto a nivel nacional como internacional y por qué?

Bueno, Yuya es un ejemplo, porque ahorita es en maquillaje y estilo de vida una de las latinas con más seguidores a nivel mundial, pero en YouTube, puede que sea Joryck que hace todo lo que es moda, que tiene un estilo muy lindo a nivel audiovisual y de vestimenta, en maquillaje hay muchísimas, sobre todo en US y en España está Happy Funny Flowers, quien es una española que tiene muchos años en YouTube y ha generado un buen lazo con sus seguidores. En Instagram, sigo a Jelac, que tiene cosas parecidas a 
lo que yo hago y así tengo varios referentes a los que sigo y me inspiran y que tomo como ejemplo.

10. ¿Cómo crees que será el futuro de YouTube?

Hoy en día los celebrity, que son la gente de tv y medios tradicionales, también están generando contenido en YouTube, tienen muchas vistas, pero no tienen fidelidad de seguidores.

Yo creo que va a haber variedad, los celebrity que pueden generar vistas y van a seguir, los influencer, que son los que finalmente tienen ese enganche con el público, entonces veo a YouTube con una diversidad, con canales con más seguidores porque es el medio que reemplaza a la tv.

Por ejemplo, los programas de farándula o los chismes, no tengo que verlos en vivo, solo abro YouTube y ahí está, ya no es necesario estar frente a la tv, para enterarte de las cosas. El YouTube va a ser la tv acompañante, la que llevas a todos lados y puedes ver en cualquier momento.

Va a terminar dejando de lado a los medios tradicionales y muchos de esos programas tradicionales ya han visto eso y es por eso que ahora todos o casi todos cuelgan sus programas en YouTube.

11. Finalmente, ¿puede detallar los siguientes aspectos de su producción?

a. Cámara(s) usada(s): Canon t4i con lente $18-55 \mathrm{~mm}$ y $50 \mathrm{~mm}$.

b. Equipo de iluminación: No tengo por ahora.

c. Equipo de audio: Micrófono externo.

d. Programas de edición utilizados: Adobe Premiere.

e. Recursos de terceros: Biblioteca de audio de YouTube y las imágenes son mías o de stock libres.

f. Fases de producción: No desarrollo un guion como tal ya que se trata de una receta. En realidad, manejo un método de paso a paso y algunas pautas con respecto a la receta que vamos a tratar en ese video. Cómo producción siempre defino una fecha para grabar, ya que al menos me toma 6 horas; veo que el ambiente esté bien decorado, que los ingredientes estén completos (no pueden faltar en pleno video), me realizo un maquillaje y peinado básico, preparo la cámara y con todo listo procedo a realizar la grabación. Para la post producción se pautea otro día porque la edición toma al menos 10 horas. Lo trabajo en una sola fecha y los videos por lo general se comparten entre martes y jueves. 


\section{Codificación abierta pa1-ca}

Tipo de informante: Productor Audiovisual

Nombre y apellido del informante: César Arana

Código: pa1-ca

\section{Preguntas que orientan la codificación abierta}

\section{Pregunta principal de investigación}

¿De qué manera los youtubers con más vistas en el Perú constituyen una modalidad emergente de producción audiovisual en la era digital?

\section{Preguntas específicas de investigación}

- ¿Cuáles son los distintos medios de producción audiovisual en la era digital?

- ¿Cómo se caracteriza el fenómeno youtubers desde una perspectiva comunicacional?

- ¿Cuáles son los youtubers con más vistas en el Perú?

- ¿De qué manera influyen los youtubers como modalidad emergente de producción audiovisual en la era digital?

\begin{tabular}{|l|l|}
\hline Entrevista & Categorías \\
\hline ¿Que implica el sistema de & Tipo de contenido (1-pa1-ca) \\
producción tradicional y su & Tipo de proyecto (2-pa1-ca) \\
diferenciación con el sistema de & Genero (3-pa1-ca) \\
producción de los youtubers? & Formato (4-pa1-ca) \\
Tienes que partir de varias cosas. & "Tienes que partir de varias cosas. Tienes \\
Tienes que partir del tipo de contenido & que partir del tipo de contenido que estés \\
(1) que estés trabajando, del tipo de & trabajando, del tipo de proyecto que quieras \\
proyecto que quieras trabajar (2); & trabajar; tienes que partir un poco del género \\
tienes que partir un poco del género & y del formato que te interese abarcar" (4-pa1- \\
(3) y del formato que te interese & ca) (3-pa1-ca) (2-pa1-ca) (1-pa1-ca). \\
abarcar (4). Tienes que partir & Público meta (5-pa1-ca) \\
conociendo muy bien a tu público, el & "Tienes que partir conociendo muy bien a tu \\
público al cual quieres llegar. & público, el público al cual quieres llegar" (5- \\
Deberías tomar en cuenta una & pa1-ca). \\
investigación sobre el tema que vas a & Investigación temática (6-pa1-ca) \\
abordar (6), que vas a tocar; mientras & "Deberías tomar en cuenta una investigación \\
mejor conozcas a tu público, mejor & sobre el tema que vas a abordar, que vas a \\
conozcas el tema, vas a manejar & tocar" (6-pa1-ca). \\
muchas y mejores variables (7) Tienes & Investigación temática (7-pa1-ca) \\
que tomar en cuenta en qué tipo de & "mientras mejor conozcas a tu público, mejor \\
plataforma vas a emitir tu contenido & conozcas el tema, vas a manejar muchas y \\
(8). Es a partir de esas variables que & mejores variables" (7-pa1-ca). \\
tienes que definir, en primer lugar, el & Tipo de plataforma (8-pa1-ca) \\
decir tipo de público, tipo de & \\
\hline
\end{tabular}


plataforma, tipo de contenido. (9). El proceso de producción tradicional (10) pasa por diferentes etapas claramente diferenciadas. Tienes una primera etapa de investigación y de preparación del proyecto, una segunda etapa de preproducción del proyecto, tienes una tercera etapa de producción y realización en sí y tienes una última etapa de postproducción $y$, dependiendo del tipo de proyecto que hayas abordado, tienes una cuarta etapa en la cual te dedicas a ver temas de promoción, distribución y lanzamiento. Por lo poco que sé acerca de la forma de producir de los youtubers (11), yo no creo que estén respetando mucho ese proceso.

¿Entonces los youtubers son más espontáneos?

(11) Yo creo que, en esa área, como lo mencionas, estamos hablando de un proceso de producción mucho más espontáneo e informal, algo más inmediato. Cuando tú trabajas bajo un método de producción tradicional, en la etapa de investigación (12), tienes que tratar de conocer a tu público, tu plataforma, el tipo de contenido. Si estuvieras trabajando un proyecto de ficción, tienes que ver el tema del guion, buscar rostros que interpreten a tus personajes y, si no es ficción, también tienes que pensar en rostros, en quiénes van a ser la imagen. (10) En la etapa de preproducción tienes que preparar todo lo que vayas a necesitar para la etapa de realización; tienes que elaborar un cronograma de trabajo, tienes que escoger a tu equipo, tienes que pensar o saber qué recursos vas a tener, con qué recursos vas a contar a nivel técnico, a nivel de dinero, a nivel de personal, tiene que estar todo completamente detallado, planificado, estructurado. En la etapa de realización, tienes que tratar de cumplir con todo lo establecido en la etapa de preproducción; no puedes exceder tiempos, no puedes excederte
"Tienes que tomar en cuenta en qué tipo de plataforma vas a emitir tu contenido" (8-pa1ca).

Conocimiento multidimensional (9-pa1-ca) "Es a partir de esas variables que tienes que definir, en primer lugar, el decir tipo de público, tipo de plataforma, tipo de contenido" (9-pa1-ca).

\section{Etapas de la producción audiovisual tradicional (10-pa1-ca)}

"El proceso de producción tradicional pasa por diferentes etapas claramente diferenciadas. Tienes una primera etapa de investigación y de preparación del proyecto, una segunda etapa de preproducción del proyecto, tienes una tercera etapa de producción y realización en sí y tienes una última etapa de postproducción $y$, dependiendo del tipo de proyecto que hayas abordado, tienes una cuarta etapa en la cual te dedicas a ver temas de promoción, distribución y lanzamiento" (10-pa1-ca).

Modo youtubers de producción audiovisual (11-pa1-ca)

"Por lo poco que sé acerca de la forma de producir de los youtubers, yo no creo que estén respetando mucho ese proceso... Yo creo que, en esa área, como lo mencionas, estamos hablando de un proceso de producción mucho más espontáneo e informal, algo más inmediato" (11-pa1-ca).

Etapa de investigación (12-pa1-ca)

"Cuando tú trabajas bajo un método de producción tradicional, en la etapa de investigación, tienes que tratar de conocer a tu público, tu plataforma, el tipo de contenido. Si estuvieras trabajando un proyecto de ficción, tienes que ver el tema del guion, buscar rostros que interpreten a tus personajes $y$, si no es ficción, también tienes que pensar en rostros, en quiénes van a ser la imagen" (12-pa1-ca). Etapas de la producción audiovisual tradicional (10-pa1-ca)

"En la etapa de preproducción tienes que preparar todo lo que vayas a necesitar para la etapa de realización; tienes que elaborar un cronograma de trabajo, tienes que escoger a tu equipo, tienes que pensar o saber qué recursos vas a tener, con qué recursos vas a contar a nivel técnico, a nivel de dinero, a nivel de 
de presupuestos, tienes que mantener un nivel de la producción y en la etapa de post producción igual tienes que cumplir con plazos. El sistema de los youtubers creo que debe estar manejado de una manera mucho más aleatoria, mucho más informal como te venía diciendo. (11) No sé qué tanto grado de planificación, de preparación puedan estar manejando ahí, pero bajo un sistema de producción formal debes tener en cuenta los pasos que te he mencionado.

Dentro de su experiencia propia en lo que son producciones nacionales, ¿cree que el público tiene más aceptación hacia las producciones de los youtubers que a las producciones nacionales tradicionales?

Depende de qué tipo de público hablamos. Si hablamos de un público adulto (13), o sea de alguien que tiene una experiencia más duradera con plataformas tradicionales como lo es el cine y la televisión, definitivamente sí se va a ir por lo tradicional. En cambio, el contenido de los youtubers (14) te habla de un público joven, un público millenial, un público juvenil, el cual es un público que no está dispuesto a consumir información mediante los medios tradicionales y en ese sentido básicamente los contenidos que hacen estas personas que han aparecido en los últimos años está dirigido a ellos.

¿Cómo percibe el proceso de retroalimentación que hay en las producciones tradicionales?

Bueno, y, dependiendo del proyecto que estés trabajando, es muy importante que midas la respuesta de tu público (15) ; eso te va a decir de alguna manera si tu propuesta está funcionando, si tu contenido está funcionando $\mathrm{y}$, de acuerdo a eso, tienes que hacer ajustes, cambios y modificaciones. En el caso de los youtubers, también considero que es personal, tiene que estar todo completamente detallado, planificado, estructurado. En la etapa de realización, tienes que tratar de cumplir con todo lo establecido en la etapa de preproducción; no puedes exceder tiempos, no puedes excederte de presupuestos, tienes que mantener un nivel de la producción y en la etapa de post producción igual tienes que cumplir con plazos".

Modo youtubers de producción audiovisual (11-pa1-ca)

"El sistema de los youtubers creo que debe estar manejado de una manera mucho más aleatoria, mucho más informal como te venía diciendo. No sé qué tanto grado de planificación, de preparación puedan estar manejando ahí, pero bajo un sistema de producción formal debes tener en cuenta los pasos que te he mencionado" (11-pa1-ca).

Público de la producción audiovisual tradicional (13-pa1-ca)

"Depende de qué tipo de público hablamos. Si hablamos de un público adulto, o sea de alguien que tiene una experiencia más duradera con plataformas tradicionales como lo es el cine y la televisión, definitivamente sí se va a ir por lo tradicional" (13-pa1-ca).

\section{Público del youtubers (14-pa1-ca)}

"En cambio, el contenido de los youtubers te habla de un público joven, un público millenial, un público juvenil. el cual es un público que no está dispuesto a consumir información mediante los medios tradicionales y en ese sentido básicamente los contenidos que hacen estas personas que han aparecido en los últimos años está dirigido a ellos" (14-pa1-ca).

Valorar la respuesta del público (15-pa1ca)

"Bueno, y, dependiendo del proyecto que estés trabajando, es muy importante que midas la respuesta de tu público; eso te va a decir de alguna manera si tu propuesta está funcionando, si tu contenido está funcionando $y$, de acuerdo a eso, tienes que hacer ajustes, cambios y modificaciones" (15-pa1-ca).

Retroalimentación de los youtubers (16pa1-ca)

"En el caso de los youtubers, también considero que es importante tener una 


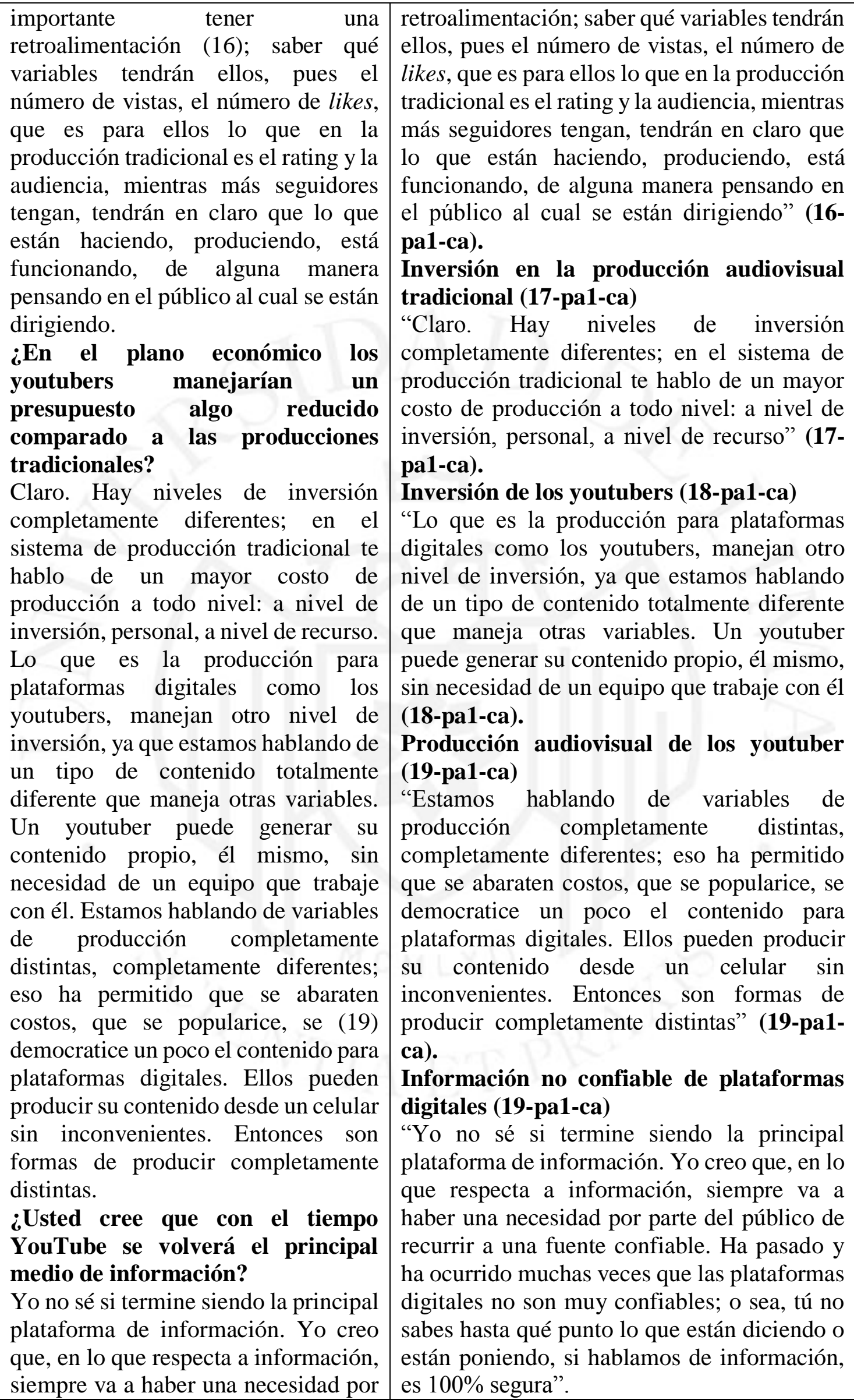


parte del público de recurrir a una fuente confiable. Ha pasado y ha ocurrido muchas veces que las plataformas digitales no son muy confiables; o sea, tú no sabes hasta qué punto lo que están diciendo o están poniendo, si hablamos de información, es $100 \%$ segura. Siempre el público va a pretender recurrir a una plataforma oficial tradicional (20) para confirmar si eso que está viendo en Facebook, Instagram o cualquier otra plataforma digital es realmente cierto o no. Entonces, siempre (21) ambas van a tener un espacio y, de hecho, están cambiando las formas de consumir; se están definiendo nuevos públicos, se están definiendo nuevas formas de producir contenido. Yo creo que estamos dentro de un proceso que está terminando de definirse.
Confianza en los medios tradicionales (20pa1-ca)

"Siempre el público va a pretender recurrir a una plataforma oficial tradicional para confirmar si eso que está viendo en Facebook, Instagram o cualquier otra plataforma digital es realmente cierto o no".

Espacios diferentes de medios tradicionales y redes (21-pa1-ca)

"Entonces, siempre ambas van a tener un espacio y, de hecho, están cambiando las formas de consumir; se están definiendo nuevos públicos, se están definiendo nuevas formas de producir contenido. Yo creo que estamos dentro de un proceso que está terminando de definirse" (21-pa1-ca).

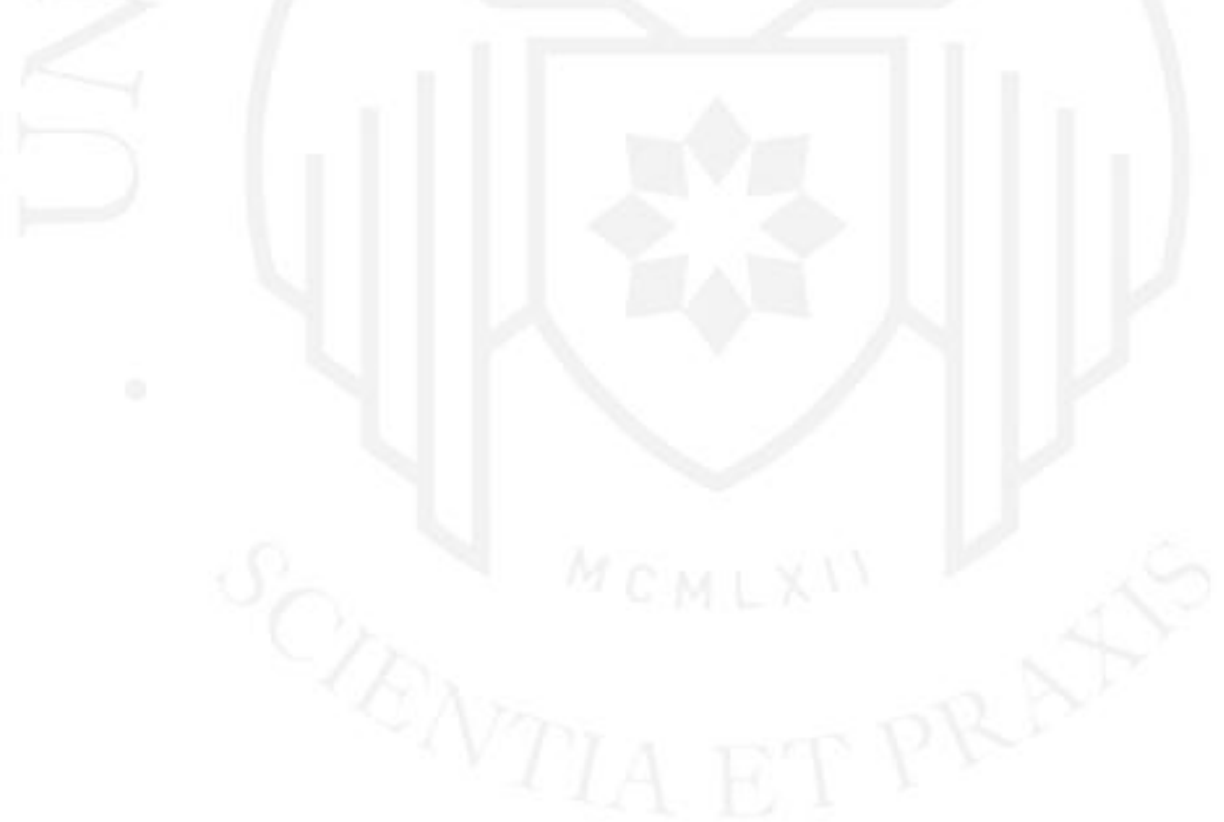




\section{Codificación abierta e-1ps}

Tipo de informante: Productor Audiovisual

Nombre y apellido del informante: Cesár Subauste

Código: e-1ps

\section{Preguntas que orientan la codificación abierta}

\section{Pregunta principal de investigación}

¿De qué manera los youtubers con más vistas en el Perú constituyen una modalidad emergente de producción audiovisual en la era digital?

\section{Preguntas específicas de investigación}

- ¿Cuáles son los distintos medios de producción audiovisual en la era digital?

- ¿Cómo se caracteriza el fenómeno youtubers desde una perspectiva comunicacional?

- ¿Cuáles son los youtubers con más vistas en el Perú?

- ¿De qué manera influyen los youtubers como modalidad emergente de producción audiovisual en la era digital?

Entrevista
En los medios tradicionales tenemos el
pre, la producción y la post. iEn los
medios digitales también se pasa por
ese proceso?
No ha cambiado el concepto de
producción (1) en los streaming o medios
digitales; lo que ha cambiado es la
dinámica y la facilidad de reaccionar y
tomar decisiones. Lo que tú encuentras
cuando analizas el sistema de producción
de los youtubers (2) más reconocidos es
que finalmente también efectúan un
proceso similar, porque esto tiene que ver
con la capacidad de planificar; cuando tú
planificas mínimamente, tienes la
capacidad de prever resultados y de
ajustar productos deseados en su versión
final. Algunos de los youtubers más
conocidos, de hecho, tú te das cuenta que
hay la concepción de un tema, el diseño
de una estructura y que, a partir de ahí,
ellos desarrollan una propuesta ante
cámaras que incluso luego editan
regularmente; (3) aunque también está el

\section{Categorías}

Cambios en la dinámica de producción de los medios digitales (1e-1ps)

"No ha cambiado el concepto de producción en los streaming o medios digitales; lo que ha cambiado es la dinámica y la facilidad de reaccionar y tomar decisiones" (1e-1ps).

Producción planificada de los youtubers reconocidos (2e-1ps)

"Lo que tú encuentras cuando analizas el sistema de producción de los youtubers más reconocidos es que finalmente también efectúan un proceso similar, porque esto tiene que ver con la capacidad de planificar; cuando tú planificas mínimamente, tienes la capacidad de prever resultados y de ajustar productos deseados en su versión final. Algunos de los youtubers más conocidos, de hecho, tú te das cuenta que hay la concepción de un tema, el diseño de una estructura y que, a partir de ahí, ellos desarrollan una propuesta ante cámaras que incluso luego editan regularmente" (2e-1ps).

Producción en vivo de los youtubers reconocidos (3e-1ps) 
otro caso, de que sea una transmisión en vivo, donde también puedes tener una pauta previa que te permite lanzarte en directo y hacer un live streaming, donde ya no necesitas de la producción y esto sale tal cual. Si nosotros hablamos de eso, podríamos hablar de otra tendencia que implica un emisor más empírico (4), que produce y que crea contenido conforme se enfrenta al medio. Entonces, improvisa el manejo de contenidos, porque está en función del instante, del momento y esta capacidad no implica necesariamente tener una planificación en la lógica de lo convencional (pre producción, producción). El vivo del digital lo que ha modificado es justamente la facilidad, el acceso y la velocidad con la que tú puedes crear y producir contenido, frente a lo que significaba producir en vivo por el medio tradicional, que demandaba fundamentalmente, por esas condiciones, una configuración de personal, equipo e infraestructura para sacar al aire una producción de esa naturaleza. El digital rompe todos los esquemas.

En términos de interacción con el público, ¿no cree usted que los medios digitales tienen mucha más interacción con el público que la que pueden tener los medios tradicionales?

Por supuesto. Eso es inherente, ya que es la principal característica del medio digital. La interactividad (6) es lo primero que marcó la diferencia con los medios tradicionales; la cuestión de la emisión en vivo ha sido un proceso posterior, pero, para comenzar, el hecho de que tú pudieras conectarte en directo a través de solo texto, significó gradualmente la aparición del chat como un mecanismo de comunicación inmediato, que cambió y transformó la lógica de otros medios de comunicación. Ya hablando específicamente de mecanismos de contacto, no nos podemos olvidar, y esto probablemente la gente más joven no lo sabe, pero los orígenes, aparece el teléfono celular y el teléfono celular se digitaliza y comienza a ofrecer una serie "aunque también está el otro caso, de que sea una transmisión en vivo, donde también puedes tener una pauta previa que te permite lanzarte en directo y hacer un live streaming, donde ya no necesitas de la producción y esto sale tal cual" (3e-1ps).

Productor audiovisual empírico (4e-1ps)

"Si nosotros hablamos de eso, podríamos hablar de otra tendencia que implica un emisor más empírico, que produce y que crea contenido conforme se enfrenta al medio. Entonces, improvisa el manejo de contenidos, porque está en función del instante, del momento y esta capacidad no implica necesariamente tener una planificación en la lógica de lo convencional (pre producción, producción)" (4e-1ps).

Modo digital de producción audiovisual (5e-1ps)

"El vivo del digital lo que ha modificado es justamente la facilidad, el acceso y la velocidad con la que tú puedes crear y producir contenido, frente a lo que significaba producir en vivo por el medio tradicional, que demandaba fundamentalmente, por esas condiciones, una configuración de personal, equipo e infraestructura para sacar al aire una producción de esa naturaleza. El digital rompe todos los esquemas" (5e-1ps).

Interactividad con el público de los medios digitales (6e-1ps)

"Por supuesto. Eso es inherente, ya que es la principal característica del medio digital. La interactividad es lo primero que marcó la diferencia con los medios tradicionales" (6e1ps).

Chat como cambio en la lógica de los medios (6e-1ps)

"el hecho de que tú pudieras conectarte en directo a través de solo texto, significó gradualmente la aparición del chat como un mecanismo de comunicación inmediato, que cambió y transformó la lógica de otros medios de comunicación" (6e-1ps).

\section{EI teléfono celular (7e-1ps)}

"Ya hablando específicamente de mecanismos de contacto, no nos podemos olvidar, y esto probablemente la gente más joven no lo sabe, pero los orígenes, aparece 
de prestaciones adicionales. Ya el hecho de que apareciera la telefonía celular comenzó a marcar un poco esa entrada como fórmula de interacción. La digitalización de este dispositivo igualmente fue superada cuando aparecen en medios digitales las primeras redes sociales. (8) El Messenger, creado por Hotmail, que fue toda una transformación, porque implicó la posibilidad de ir gradualmente cambiando los comportamientos de la forma de interacción y de contacto del público $\mathrm{y}$, luego de eso, una serie de servicios se vieron afectados y terminaron desapareciendo. A eso tenemos que sumarle que probablemente se dice que fue iPhone, pero Apple, a partir de la configuración ya de una tecnología digital a través de un dispositivo móvil de la telefonía inteligente, ahí es donde se marca otro hito en el gran cambio de lo que significa esta fórmula de interacción $\mathrm{y}$ de transformación de los contenidos frente a los medios convencionales, a tal punto que los medios convencionales no saben bien cómo hacerlo, pero tienen que ver la manera de cómo integrar día a día mecanismos digitales para los contenidos que producen.

¿En el punto económico donde se ve que hay mayor inversión en los medios digitales o tradicionales?

Los medios convencionales siguen demandando inversiones muy altas en el tema de equipos, infraestructura y de acceso a los mecanismos de distribución y difusión de estos contenidos; mientras que lo digital siempre, desde un principio, ha abaratado costos. Entonces, la diferencia marcada es en lo que es el tema económico para una producción más trabajada.

¿Son más profesionales los medios tradicionales que los medios digitales?

No es que sean más profesionales, sino que los medios digitales son una experiencia más empírica para el que la realiza. Siempre su contenido va a ser el teléfono celular y el teléfono celular se digitaliza y comienza a ofrecer una serie de prestaciones adicionales" (7e-1ps).

\section{El Messenger y Hotmail (8e-1ps)}

"La digitalización de este dispositivo igualmente fue superada cuando aparecen en medios digitales las primeras redes sociales. El Messenger, creado por Hotmail, que fue toda una transformación, porque implicó la posibilidad de ir gradualmente cambiando los comportamientos de la forma de interacción y de contacto del público y, luego de eso, una serie de servicios se vieron afectados y terminaron desapareciendo" (8e1ps).

\section{Telefonía inteligente (9e-1ps)}

"A eso tenemos que sumarle que probablemente se dice que fue iPhone, pero Apple, a partir de la configuración ya de una tecnología digital a través de un dispositivo móvil de la telefonía inteligente, ahí es donde se marca otro hito en el gran cambio de lo que significa esta fórmula de interacción y de transformación de los contenidos frente a los medios convencionales, a tal punto que los medios convencionales no saben bien cómo hacerlo, pero tienen que ver la manera de cómo integrar día a día mecanismos digitales para los contenidos que producen" (9e-1ps).

Inversión en medios tradicionales (10e1ps)

"Los medios convencionales siguen demandando inversiones muy altas en el tema de equipos, infraestructura y de acceso a los mecanismos de distribución y difusión de estos contenidos" (10e-1ps).

Inversión en medios digitales (11e-1ps)

"mientras que lo digital siempre, desde un principio, ha abaratado costos. Entonces, la diferencia marcada es en lo que es el tema económico para una producción más trabajada" (11e-1ps).

Naturaleza empírica y espontanea de los medios digitales (12e-1ps)

"No es que sean más profesionales, sino que los medios digitales son una experiencia más empírica para el que la realiza. Siempre su contenido va a ser algo espontaneo y basado en la experiencia, y eso va a depender del uso 
algo espontaneo y basado en la experiencia, y eso va a depender del uso que le dé al dispositivo que tiene para grabar el contenido en el momento exacto.

¿Qué opina del tema de los auspicios en los medios digitales?

Eso ha cambiado muchísimo, y sobre todo en los últimos años, ya que la penetración de estos mecanismos, como redes sociales y medios digitales, ha hecho despertar a las marcas y a las empresas interesadas en llegar a un nuevo público, y eso ha derivado en que se ha convertido y se ha reconfigurado el mercado de los anuncios. A las marcas siempre les va a convenir hacer tratos con un nuevo público, como es el que tienen los youtubers, que es un público joven.

¿Cree usted que los medios digitales sean el principal medio de acceso a la información?

Creo que tarde o temprano esto va a ocurrir, porque ya estamos en esta lógica. Ya se ve en varias investigaciones un gran consumo de medios digitales en comparación de los tradicionales; gran parte de los estudios que hay sobre los medios convencionales indican que hay un descenso notable en lo que es el servicio de información y entretenimiento, debido a los medios digitales. (15) La televisión y los medios convencionales no tienen respuesta hacia el boom de los medios digitales y tienen que buscar adaptarse y digitalizar sus servicios, e incluso los vemos en las aplicaciones que han lanzado para ver una programación vía Internet y ya no por tv. Con el pasar de los años, los usos y costumbres van a cambiar y los millenials van a estar en la cabeza, y ellos son los principales usuarios de medios digitales. que le dé al dispositivo que tiene para grabar el contenido en el momento exacto" (12e1ps).

Youtubers y la reconfiguración del mercado de los anuncios (13e-1ps)

"Eso ha cambiado muchísimo, y sobre todo en los últimos años, ya que la penetración de estos mecanismos, como redes sociales y medios digitales, ha hecho despertar a las marcas y a las empresas interesadas en llegar a un nuevo público, y eso ha derivado en que se ha convertido y se ha reconfigurado el mercado de los anuncios. A las marcas siempre les va a convenir hacer tratos con un nuevo público, como es el que tienen los youtubers, que es un público joven" (13e1ps).

\section{Lógica hegemónica de los medios digitales (14e-1ps)}

"Creo que tarde o temprano esto va a ocurrir, porque ya estamos en esta lógica. Ya se ve en varias investigaciones un gran consumo de medios digitales en comparación de los tradicionales; gran parte de los estudios que hay sobre los medios convencionales indican que hay un descenso notable en lo que es el servicio de información y entretenimiento, debido a los medios digitales...Ya hoy en día es raro ver a alguien escuchando radio o viendo televisión. Es más común ver a gente pegada a una Tablet o a su teléfono celular" (14e-1ps).

Adaptación de los medios tradicionales (15e-1ps)

"La televisión y los medios convencionales no tienen respuesta hacia el boom de los medios digitales y tienen que buscar adaptarse y digitalizar sus servicios, e incluso los vemos en las aplicaciones que han lanzado para ver una programación vía Internet y ya no por tv." (15e-1ps).

Liderazgo de los millenials (16e-1ps)

"Con el pasar de los años, los usos y costumbres van a cambiar y los millenials van a estar en la cabeza, y ellos son los principales usuarios de medios digitales" (16e-1ps). 


\section{Codificación abierta yt-3da}

\section{Tipo de informante: Youtuber}

\section{Nombre y apellido del informante: Daniela Acosta}

Código: yt-3da

\section{Preguntas que orientan la codificación abierta}

\section{Pregunta principal de investigación}

¿De qué manera los youtubers con más vistas en el Perú constituyen una modalidad emergente de producción audiovisual en la era digital?

\section{Preguntas específicas de investigación}

- Identificar los distintos medios de producción audiovisual en la era digital.

- Describir el fenómeno youtubers desde una perspectiva comunicacional.

- Identificar a los youtubers con más vistas en el Perú.

- Determinar la influencia de los youtubers como modalidad emergente de producción audiovisual en la era digital.

\section{Entrevista \\ 1. ¿Consideras que hay diferencias entre la televisión y YouTube? ¿Cuáles crees que son las principales diferencias? \\ En YouTube tú tienes el control, vas a tu ritmo, no tienes que esperar una hora determinada para sentarte a ver algo, tú decides lo que quieras, ver al momento que tu desees ver y el contenido también lo eliges, de acuerdo a tus gustos, en cambio en la tv hay una plancha de contenido y tu tendrías que escoger en que momento verlo, aparte hoy en día, con toda la tecnología móvil, puedes verlo donde sea, no tienes que estar sentado frente a la tv.}

2. ¿Consideras a YouTube un medio emergente? ¿Por qué?

Ya no sé si tan emergente, emergente fue unos años atrás, yo creo que hoy en día es una plataforma de contenido que está ya en una edad media, es decir no está en pañales, está empezando a desarrollarse con más potencia, ya hay youtubers con más de 30 millones de suscriptores, entonces creo que ya está bastante avanzado. No lo veo en auge y siento más bien que este camino a ser una plataforma gigante en entretenimiento.

\section{Categorías}

Libertad de elegir en YouTube (1yt3da)

"En YouTube tú tienes el control, vas a tu ritmo, no tienes que esperar una hora determinada para sentarte a ver algo, tú decides lo que quieras, ver al momento que tu desees ver y el contenido también lo eliges, de acuerdo a tus gustos, en cambio en la tv hay una plancha de contenido y tu tendrías que escoger en que momento verlo, aparte hoy en día, con toda la tecnología móvil, puedes verlo donde sea, no tienes que estar sentado frente a la tv" (1yt-3da).

YouTube un medio ex expansión (2yt3da)

"Ya no sé si tan emergente, emergente fue unos años atrás, yo creo que hoy en día es una plataforma de contenido que está ya en una edad media, es decir no está en pañales, está empezando a desarrollarse con más potencia, ya hay youtubers con más de 30 millones de suscriptores, entonces creo que ya está bastante avanzado. No lo veo en auge y siento más 


\begin{abstract}
3. ¿De qué manera crees que han impactado los youtubers en el público en general, respecto a los medios tradicionales?

El youtuber es un generador de contenido vs el celebrity $\mathrm{o}$ artista de tv que está en un contenido impuesto, al celebrity se le contrata para determinado contenido, determinada plancha de contenido, ya establecida, mientras que el youtuber, genera su propio contenido, entonces hay un valor agregado en eso, que es una persona como tú o como yo, que está generando un contenido para un público que piensa como él y que tiene los mismos gustos de él, entonces tiene más empatía.
\end{abstract}

4. Para comunicar tus ideas y proyectos, ¿qué plataformas digitales utilizas y cómo las utilizas?

Básicamente Instagram es una de las redes más fuerte que tengo después de YouTube, Instagram Historias, me permite estar cerca de mis seguidores en el día a día, Facebook es una plataforma que sirve mucho más a las personas que tienen trabajo de oficina y tienen abierta esa red social en la computadora como distracción, pero más es una herramienta para compartir memes, información, pero ya no es tanto el target, mientras que Instagram ahorita, luego de YouTube es una de las redes más fuertes que tengo.

5. ¿Qué sensaciones o emociones buscas generar en tu público objetivo?

Lo que busco es que tengan la moda al alcance del bolsillo, la intención de mi canal, no solo es mostrar moda porque sí, 'por las tendencias o conseguir lo caro, ósea el primer grupo de influencers en el tema, estaba dedicado a mostrar marcas caras mientras que había un mercado desatendido y entonces como que dije, puedes vestirte igual de bien, puedes verte increíble pero, a bajo presupuesto, entonces creo que una de las cosas que busco es mostrar ofertas , mostrar cosas que la mayoría de personas puede tener y vestirse bien.

6. ¿Es posible para un youtuber profesionalizarse en su trabajo, tanto en lo económico como en los aspectos técnicos, sin correr el riesgo de perder lo que atrae a su público de este medio?

En lo económico, las brechas son grandes pero eso, no genera mucha diferencia, creo yo, en el bien que este camino a ser una plataforma gigante en entretenimiento" (2yt-3da).

El youtuber vs el celebrity (3yt-3da)

"El youtuber es un generador de contenido vs el celebrity o artista de tv que está en un contenido impuesto, al celebrity se le contrata para determinado contenido, determinada plancha de contenido, ya establecida, mientras que el youtuber, genera su propio contenido" (3yt-3da).

Empatía entre el youtuber y su público(3yt-3da)

"el youtuber, genera su propio contenido, entonces hay un valor agregado en eso, que es una persona como tú o como yo, que está generando un contenido para un público que piensa como él y que tiene los mismos gustos de él, entonces tiene más empatía" (3yt-3da).

Combinación Youtube e Instagram (4yt-3da)

"Básicamente Instagram es una de las redes más fuerte que tengo después de YouTube, Instagram Historias, me permite estar cerca de mis seguidores en el día a día, Facebook es una plataforma que sirve mucho más a las personas que tienen trabajo de oficina y tienen abierta esa red social en la computadora como distracción, pero más es una herramienta para compartir memes, información, pero ya no es tanto el target, mientras que Instagram ahorita, luego de YouTube es una de las redes más fuertes que tengo" (4yt-3da).

Moda al alcance de su bolsillo (5yt-3da) "Lo que busco es que tengan la moda al alcance del bolsillo, la intención de mi canal, no solo es mostrar moda porque sí, 'por las tendencias o conseguir lo caro, ósea el primer grupo de influencers en el tema, estaba dedicado a mostrar marcas caras mientras que había un mercado desatendido y entonces como que dije, puedes vestirte igual de bien, puedes verte" (5yt-3da).

Enfocarse en una necesidad (6yt-3da) "el primer grupo de influencers en el tema, estaba dedicado a mostrar marcas caras mientras que había un mercado 
gusto del consumidor, podríamos hablar de lo que tú me dices, los auspicios, en el caso de la tv lo que es auspiciado, es el programa, mientras que nosotros los youtubers como marcas personales, somos los que manejamos los auspicios, aparte, lo ideal es que trabajo con marcas en las que yo creo y que consumo y veo que es favorable para recomendar a mis seguidores mientras que en la tv, en la menciones, te imponen y haces publicidad a productos que no usas, sin saber realmente si son buenas o malas, en cambio, en mi caso, si bien es cierto, hay un intercambio de dinero si yo menciono o recomiendo una marca, es porque la uso la voy a usar y creo en ella.

7. Ahora cerremos con unas preguntas más personales. ¿Por qué decidiste ser youtuber? Hace muchísimos años, cuando estaba en la universidad, quería compartir mis conocimientos de maquillaje y en ese entonces, porque mis primeras publicaciones fueron sobre maquillajes y entonces, tener la cantidad de suscriptores era bastante para el momento de YouTube en ese entonces, de hecho yuya que hoy tiene más de 3 millones de seguidores, en ese entonces tenía cinco mil, seis mil seguidores y era muchísimo para ese entonces, entonces yo quise compartir mis conocimientos y mis espectadores empezaron siendo mis amigos, luego lo deje y cuando lo retome y lo que quería era seguir mostrando mis conocimientos y generando contenido, quería compartir lo que yo hacía de una forma dinámica y alcanzar a las personas con ese tipo de conocimiento, entonces no es que yo quise ser youtuber si no que quise compartir conocimientos y cosas que me gustaban para un grupo de chicas que tenían mis mismos gustos.

8. ¿Te consideras un influencer? ¿Cuál es la diferencia entre un influencer y un youtuber? Un youtuber es un influencer, un influencer es una persona que está influyendo en lo demás con opiniones, consejos, recomendaciones con tips, etc. Siendo así, si me considero influencer, porque con lo que yo hago estoy influyendo a las personas no solo en opinión si no en acción, lo que yo digo y recomiendo, lo compran y van a la marca y dicen vengo por Daniela y es por eso que me buscan y me auspician y es toda una cadena digamos digital-comercial, donde lo que desatendido y entonces como que dije, puedes vestirte igual de bien, puedes verte increíble, pero, a bajo presupuesto, entonces creo que una de las cosas que busco es mostrar ofertas, mostrar cosas que la mayoría de personas puede tener y vestirse bien" (6yt-3da).

Youtuber como marca personal $(7 \mathrm{yt}$ 3da)

"nosotros los youtubers como marcas personales, somos los que manejamos los auspicios" (7yt-3da).

Youtuber anunciante comprometido (8yt-3da)

"lo ideal es que trabajo con marcas en las que yo creo y que consumo y veo que es favorable para recomendar a mis seguidores mientras que, en la tv, te imponen y haces publicidad a productos que no usas, sin saber realmente si son buenas o malas, en cambio, en mi caso, si bien es cierto, hay un intercambio de dinero si yo menciono o recomiendo una marca, es porque la uso la voy a usar y creo en ella" (8yt-3da).

\section{Compartir conocimientos (9yt-3da)}

"lo que quería era seguir mostrando mis conocimientos y generando contenido, quería compartir lo que yo hacía de una forma dinámica y alcanzar a las personas con ese tipo de conocimiento" (9yt-3da). Gustos comunes con el público (10yt3da)

"yo quise ser youtuber si no que quise compartir conocimientos y cosas que me gustaban para un grupo de chicas que tenían mis mismos gustos" (10yt-3da).

\section{Youtuber como influencer}

"Un youtuber es un influencer, un influencer es una persona que está influyendo en lo demás con opiniones, consejos, recomendaciones con tips, etc. Siendo así, si me considero influencer, porque con lo que yo hago estoy influyendo a las personas no solo en opinión si no en acción, lo que yo digo y recomiendo, lo compran y van a la marca y dicen vengo por Daniela" (10yt-3da). Cadena digital comercial (11yt-3da) 
está de por medio, es mi recomendación, mi influencia y si me considero influencer, y un youtuber también puede ser un influencer

9. ¿Cuáles son tus referentes en YouTube, tanto a nivel nacional como internacional y por qué?

Bueno, Yuya es un ejemplo, porque ahorita es en maquillaje y estilo de vida una de las latinas con más seguidores a nivel mundial, pero en YouTube, puede que sea Joryck que hace todo lo que es moda, que tiene un estilo muy lindo a nivel audiovisual y de vestimenta, en maquillaje hay muchísimas, sobre todo en US y en España está Happy funny flowers, quien es una española que tiene muchos años años en YouTube y ha generado un buen lazo con sus seguidores, en Instagram sigo a Jelac, que tiene cosas parecidas a lo que yo hago y así tengo varios referentes a los que sigo y me inspiran y que tomo como ejemplo.

10. ¿Cómo crees que será el futuro de YouTube?

Hoy en día los celebrity, que son la gente de tv y medios tradicionales, también están generando contenido en YouTube, tienen muchas vistas, pero no tienen fidelidad de seguidores.

Yo creo que va a haber variedad, los celebrity que pueden generar vistas y van a seguir, los influencer, que son los que finalmente tienen ese enganche con el público, entonces veo a YouTube con una diversidad, con canales con más seguidores porque es el medio que reemplaza a la tv.

Por ejemplo, los programas de farándula o los chismes, no tengo que verlos en vivo, solo abro YouTube y ahí está, ya no es necesario estar frente a la tv, para enterarte de las cosas.

El YouTube va a ser la tv acompañante, la que llevas a todos lados y puedes ver en cualquier momento.

Va a terminar dejando de lado a los medios tradicionales y muchos de esos programas tradicionales ya han visto eso y es por eso que ahora todos o casi todos cuelgan sus programas en YouTube. "y es por eso que me buscan y me auspician y es toda una cadena digamos digital-comercial, donde lo que está de por medio, es mi recomendación, mi influencia y si me considero influencer, y un youtuber también puede ser un influencer" (11yt-3da)

Inspirados en similares (12yt-3da)

"Bueno Yuya es un ejemplo, porque ahorita es en maquillaje y estilo de vida una de las latinas con más seguidores a nivel mundial, pero en YouTube, puede que sea Joryck que hace todo lo que es moda, que tiene un estilo muy lindo a nivel audiovisual y de vestimenta, en maquillaje hay muchísimas, sobre todo en US y en España está Happy funny flowers" (12yt3da).

\section{Celebrity en YouTube (13yt-3da)}

"Hoy en día los celebrity, que son la gente de tv y medios tradicionales, también están generando contenido en YouTube, tienen muchas vistas, pero no tienen fidelidad de seguidores" (13yt-3da).

\section{Fidelidad de los seguidores (14yt-3da)}

"Hoy en día los celebrity, que son la gente de tv y medios tradicionales, también están generando contenido en YouTube, tienen muchas vistas, pero no tienen fidelidad de seguidores" (14yt-3da).

YouTube reemplaza a la TV (15yt-3da) "entonces veo a YouTube con una diversidad, con canales con más seguidores porque es el medio que reemplaza a la tv" (15yt-3da).

Combinación medios tradicional y YouTube (16yt-3da)

"Va a terminar dejando de lado a los medios tradicionales y muchos de esos programas tradicionales ya han visto eso y es por eso que ahora todos o casi todos cuelgan sus programas en YouTube" (16yt-3da). 


\section{Codificación abierta yt-2ka}

\section{Tipo de informante: Youtuber}

Nombre y apellido del informante: Karina Arancibia

Código: yt-2ka

\section{Preguntas que orientan la codificación abierta}

\section{Pregunta principal de investigación}

¿De qué manera los youtubers con más vistas en el Perú constituyen una modalidad emergente de producción audiovisual en la era digital?

\section{Preguntas específicas de investigación}

- ¿Cuáles son los distintos medios de producción audiovisual en la era digital?

- ¿Cómo se caracteriza el fenómeno youtubers desde una perspectiva comunicacional?

- ¿Cuáles son los youtubers con más vistas en el Perú?

- ¿De qué manera influyen los youtubers como modalidad emergente de producción audiovisual en la era digital?

\section{Entrevista \\ 1. ¿Consideras que hay diferencias entre la televisión y YouTube? ¿Cuáles crees que son las principales diferencias?}

En YouTube, tu entras directamente a lo que quieres elegir (1), ósea tú buscas de frente, no estas esperando como en la televisión a que llegue la información si no que, aquí tienes el link de libre acceso para buscar directamente lo que necesitas, sin necesidad de establecer un horario o saltándote de ver contenidos extras.

Pero también, está la contraparte de que en YouTube para que llegues a un canal o información específica por encima te van a salir opciones que no son de tu país u otros contenidos distintos y tienes que darte tiempo para llegar a la información que finalmente vas a utilizar.

Una vez que llegas a un tema te lleva a temas relacionados de tu interés y es algo que te sirve para que el tiempo de búsqueda sea menor.

2. ¿Consideras a YouTube un medio emergente? ¿Por qué?

Considero que ha sido un medio emergente, pero hoy en día ya está establecido porque ya la gente que entra a YouTube es gente que ya sabe específicamente lo que ha ido a buscar, años atrás, en el 2007 cuando yo estaba en el colegio, YouTube

\section{Categorías}

YouTube y el derecho a elegir (1yt-2ka)

"En YouTube, tu entras directamente a lo que quieres elegir (1), ósea tú buscas de frente, no estas esperando como en la televisión a que llegue la información si no que, aquí tienes el link de libre acceso para buscar directamente lo que necesitas" (1yt-2ka).

Prevalencia de otros países en YouTube (2yt-2ka)

"Pero también, está la contraparte de que en YouTube para que llegues a un canal o información específica por encima te van a salir opciones que no son de tu país" (2yt2ka).

Tiempo para buscar información (3yt-2ka) 
recién comenzaba incluso el contenido que había antes, era completamente distinto, ahora se genera contenido para cada uno de los géneros que se necesite, historia, pastelería, viajes, gamers, hay más variedad y eso es lo que lo ha convertido en medio emergente, porque siempre hay gente que quiere contar algo y nunca habían tenido una plataforma que les permita llegar a todos, sin necesidad de un casting como lo es en la televisión, ahora todos pueden comunicar algo y si es de valor se vuelve de interés hacía los demás.

3. ¿De qué manera crees que han impactado los youtubers en el público en general, respecto a los medios tradicionales?

Han generado fidelidad con sus seguidores, porque finalmente les están dando contenido de calidad, si tú ves digamos a escalas de años anteriores a ahora, incluso los mismos youtubers han ido evolucionando sus canales, han ido agregándoles más contenido, el tema de edición ha sido mucho más pulido, porque si tú ves en retrospectiva antes lo hacían en escenarios más simples, ahora ponen escenarios más sofisticados y te dan opciones para ofrecer diferentes estilos eso en el modo audio visual.

Esto se da a medida de las respuestas que tienes de tu público y eso hace que tú mismo te retes a mejorar, es como en cualquier otro trabajo, si tú no vas mejorando tus estándares de calidad, a la larga la gente lo va a dejar de ver, es igualito a lo que pasa en la tv, si tú no vas modificando los programas a largo plazo la gente se satura y deja de verlos.

A diferencia de un programa de tv, YouTube, te permite tener mucha más cercanía con el público que te está viendo, te permite por ejemplo en mi caso que yo hago recetas te permite que abajo la gente comente preguntándote sobre esa receta o si les ha quedado alguna duda cosa que en la tv no se puede hacer, porque a veces para llegar al personaje que está detrás de la tv es como que no te permite tener esa cercanía y es lo que hay y se acabó, en cambio lo que se ha creado a través del YouTube (9) son comunidades donde el creador de contenido tiene mucha más cercanía y acceso a poder conversar con sus seguidores o su público objetivo hasta cierto punto, que eso a parte ya se viene reforzando a través de otras redes sociales que vas involucrando además de YouTube ósea para tener un canal de comunicación mucho más directo o también la plataforma que ahora tiene YouTube que tú puedes lanzar el video inbox y durante el lanzamiento del "tienes que darte tiempo para llegar a la información que finalmente vas a utilizar.

Una vez que llegas a un tema te lleva a temas relacionados de tu interés y es algo que te sirve para que el tiempo de búsqueda sea menor" (3yt-2ka).

Información diversa y segmentada en YouTube (4yt2ka)

"ahora se genera contenido para cada uno de los géneros que se necesite, historia, pastelería, viajes, gamers, hay más variedad y eso es lo que lo ha convertido en medio emergente, porque siempre hay gente que quiere contar algo y nunca habían tenido una plataforma que les permita llegar a todos" (4yt-2ka).

Derecho y posibilidad de comunicar en YouTube (5yt2ka)

"hay gente que quiere contar algo y nunca habían tenido una plataforma que les permita llegar a todos, sin necesidad de un casting como lo es en la televisión, ahora todos pueden comunicar algo y si es de valor se vuelve de interés hacía los demás" (5yt-2ka)

Profesionalización de los youtuber (6yt-2ka)

"Han generado fidelidad con sus seguidores, porque finalmente les están dando contenido de calidad, si tú ves digamos a escalas de años anteriores a ahora, incluso los mismos youtubers han ido evolucionando sus canales, han ido agregándoles más contenido, el tema de edición ha sido mucho más pulido, porque si tú ves en retrospectiva 
video tú estás conectado y puedes ir respondiéndoles las dudas a las personas que están ahí.

4. Para comunicar tus ideas y proyectos, ¿qué plataformas digitales utilizas y cómo las utilizas?

(10) Yo utilizo YouTube para hacer videos de

recetas, Instagram y Facebook para poder

comunicarme y como medio de venta.

Cuando empecé con YouTube, ósea hace años yo quería hacerlo, pero no sé, me daba vergüenza de repente, o decía de repente el contenido que voy a hacer no le va a interesar a la gente, que se yo, pero hasta que un día dije, ok, lo voy a probar y vamos a ver qué tal me va y tuve muy buena respuesta, lo que hago para complementar porque obviamente al entrar a YouTube es un terreno nuevo para mí, porque YouTube funciona o sea la manera cómo funciona YouTube sobre (11) cómo obtener seguidores es muy distinta a la de Facebook o Instagram, porque en YouTube tú tienes que realmente generar un gran interés con tu suscriptor para que el apriete el botoncito, no es como el otro, que pones me gusta, no me gusta, te sigo o no, si no que en YouTube, para que tú puedas generar una empatía con tu suscriptor él tiene que ver unos 4 o 5 vídeos de su interés para decidirse a poner el clic en la ventanita de suscribir, ahora como hago yo, para complementar eso porque obviamente YouTube es el medio menos conocido para mí, es que empecé a través de las redes sociales tipo Facebook o Instagram a hacer rondas de preguntas sobre que vídeos quieren que coloqué en YouTube, ósea involucro a todas las redes sociales, por ejemplo hago la ronda de preguntas a través de Instagram, donde aprovecho para contestar dudas a la gente, que va viendo los videos sobre las recetas o que de repente quieran empezar a hacer un negocio y no saben cómo hacerlo, yo trato de responderles por ahí, de todos los pedidos, lo que ellos quieren, es que les enseñe como hacer la cotización de un producto para no perder plata, para ganar. A través de Instagram, he tenido una temática para lanzarla en YouTube, al final todo está involucrado o, por ejemplo, cuando yo subo un vídeo en YouTube, dónde publico mi receta es en Facebook y en la cajita de descripción te pongo el vínculo que te lleva a mi vídeo en YouTube. Al final, uno todas las redes sociales, porque estoy generando una (12) comunidad multiplataforma y eso es el medio por el que empecé a trabajar desde el año pasado, que arranque con lo del YouTube y que he tratado de mantener hasta ahora y de hecho me ha dado buenos resultados antes lo hacían en escenarios más simples, ahora ponen escenarios más sofisticados y te dan opciones para ofrecer diferentes estilos eso en el modo audio visual (6yt-2ka).

Mejoramiento continuo del trabajo del youtuber (7yt2ka)

"Esto se da a medida de las respuestas que tienes de tu público y eso hace que tú mismo te retes a mejorar, es como en cualquier otro trabajo, si tú no vas mejorando tus estándares de calidad, a la larga la gente lo va a dejar de ver, es igualito a lo que pasa en la tv, si tú no vas modificando los programas a largo plazo la gente se satura y deja de verlos" (7yt-2ka).

Cercanía del youtuber con su público (8yt-2ka)

"YouTube, te permite tener mucha más cercanía con el público que te está viendo, te permite por ejemplo en mi caso que yo hago recetas te permite que abajo la gente comente preguntándote sobre esa receta o si les ha quedado alguna duda cosa que en la tv no se puede hacer, porque a veces para llegar al personaje que está detrás de la tv es como que no te permite tener esa cercanía" (8yt-2ka).

YouTube son comunidades (9yt-2ka)

"YouTube son comunidades donde el creador de contenido tiene mucha más cercanía y acceso a poder conversar con sus seguidores o su público objetivo hasta cierto punto, que eso a parte ya se viene reforzando a través de otras redes sociales" (9yt-2ka). 
5. ¿Qué sensaciones o emociones buscas generar en tu público objetivo?

Impulsarlos a que emprendan sus negocios, pero también enseñarles, a que pueden hacer pastelería o cocinar, sin que les sea algo difícil, (13) normalmente cuando yo he visto algún tipo de video y es en lo que yo me he tratado de enfocar más, al haber trabajado en recetarios para diferentes revistas es que había miles de recetarios y miles de videos donde te dicen esto se hace de esta manera u otra, pero no te dan las pautas ni las cantidades necesarias y cuando el usuario lo realizaba, no le salía como debería salirle, entonces cuando empecé a escribir en revistas y una de mis políticas era revisar que todo lo que decían en las recetas estaban bien y si había algo mal que la arreglen y me la vuelvan a dar para poder dar la información correcta, de esa manera aprendía a leer recetas antes de que estudiar pastelería, eso me ha ayudado a tener una imagen de chef en línea generando que me pregunten cosas acerca de recetas y yo les respondo para que puedan realizar su cocina de la mejor manera.

6. ¿Es posible para un youtuber profesionalizarse en su trabajo, tanto en lo económico como en los aspectos técnicos, sin correr el riesgo de perder lo que atrae a su público de este medio?

Ahora la profesionalización no es tan necesaria, por el mismo avance de la tecnología y con el pasar del tiempo, está al alcance de todos, es por eso, que para comunicar o generar contenido, no necesitas tanto equipo ni producción como en la Tv.

7. Ahora cerremos con unas preguntas más personales. ¿Por qué decidiste ser youtuber?

Al principio, me daba vergüenza o pensaba que no iba a generar interés por lo que quiero comunicar, pero es cuestión de perder el miedo y soltarte, al final de cuentas si tú crees que tu contenido es de valor, va a servir y vas a tener seguidores, siempre $\mathrm{y}$ cuando hagas caso a lo que la gente pide y necesite de acuerdo a tu rubro

8. ¿Te consideras un influencer? ¿Cuál es la diferencia entre un influencer y un youtuber?

Creo que en el aspecto de pastelería sí, lo que pasa es que creo, que hay unas mediciones para tipos de influencers, como son los microinfluencers, que es algo mucho más puntual para un solo aspecto , una cantidad de seguidores más pequeña que es lo que yo considero que tengo ahorita, pero si considero que influyo de manera positiva en la gente que está viendo el producto que yo hago, porque a través de mi trabajo, ellos me están mandando mensajes y un

\section{Combinación de redes sociales (10yt-2ka) \\ "Yo utilizo YouTube para hacer videos de recetas, Instagram y Facebook para poder comunicarme y como medio de venta" (10yt-2ka).}

YouTube más exigente que otras redes (11yt-2ka).

"porque YouTube funciona o sea la manera cómo funciona YouTube sobre cómo obtener seguidores es muy distinta a la de Facebook o Instagram, porque en YouTube tú tienes que realmente generar un gran interés con tu suscriptor para que el apriete el botoncito, no es como el otro, que pones me gusta, no me gusta, te sigo o no , si no que en YouTube, para que tú puedas generar una empatía con tu suscriptor él tiene que ver unos 4 o 5 vídeos de su interés para decidirse a poner el clic en la ventanita de suscribir" (11yt-2ka).

\section{Comunidad multiplataforma} (12yt-2ka)

Al final, uno todas las redes sociales, porque estoy generando una comunidad multiplataforma y eso es el medio por el que empecé a trabajar desde el año pasado, que arranque con lo del YouTube y que he tratado de mantener hasta ahora $y$ de hecho me ha dado buenos resultados" (12yt-2ka).

Didáctica de lo fácil (13yt-
2ka)
"Impulsarlos a que emprendan
sus negocios, pero también
enseñarles, a que pueden hacer
pastelería o cocinar, sin que les
sea algo difícil" (13yt-2ka).


montón de gente me ha escrito, para decir que empezaron a hacer su negocio de pastelería cuando empezaron a ver a mis videos o que los tips que les doy les han servido, otras personas me dicen, me compré la batidora que me recomendaste y bacán y al final, si te das cuenta que tienes un impacto positivo en la gente.

Influencer se le llama a la persona que ya bien sea youtuber o instagramer, impacta de manera positiva en los seguidores que tiene, pero hay niveles para nombrar influencers o microinfluencers, de acuerdo a las medidas que tienen las empresas de marketing. Y estos grupos pequeños, los microinfluencers, tiene seguidores más fieles que los macros influencers.

9. ¿Cuáles son tus referentes en YouTube, tanto a nivel nacional como internacional y por qué?

Bueno lo más loco, es que yo no sigo o no tengo referentes de canales de pastelería, pero lo que si hago es seguir estilos por ejemplo del canal, "Mis pastelitos", luego a veces me pongo a ver tutoriales de diferentes youtubers a nivel mundial. Si tengo que darte un referente sería el de "Mis pastelitos" ya que da información importante, me gusta su estilo y si me voy a otros youtubers, sigo youtubers de lecturas, que recomiendan libros y hacen críticas y te resumen series y películas, en si sigo YouTube para relajarme.

10. ¿Cómo crees que será el futuro de YouTube? Que se mantenga siendo una plataforma que le da libre acceso a la información a la gente, creo que YouTube hasta cierto punto, ha ayudado a que el mundo globalizado se haya podido converger en un solo sitio, ósea tienes acceso a mucha información de todo el mundo y de diferentes rubros y para mi es importante, que YouTube siga siendo una plataforma de acceso para todos y ahora existe el YouTube Premium y ahora puedes ver contenido sin publicidad y es algo bueno, pero tampoco estoy en contra de la publicidad porque entiendo que los youtubers, están monetizando sus contenidos y les pagan por ese trabajo. YouTube va a seguir mejorando como lo ha hecho hasta ahora, que puedes editar videos y poner efectos y música y eso es bueno y muchas veces es gracias a la publicidad. Que continúe teniendo esa facilidad para unir al mundo con diferentes temáticas y generando esa confianza de que vas a subir tu video de manera rápida y segura.
Identificar el enfoque (13yt2ka)

"había miles de recetarios y miles de videos donde te dicen esto se hace de esta manera u otra, pero no te dan las pautas ni las cantidades necesarias y cuando el usuario lo realizaba, no le salía como debería salirle" (13yt-2ka).

Profesionalización

no necesaria (14yt-2ka)

"Ahora la profesionalización no es tan necesaria, por el mismo avance de la tecnología y con el pasar del tiempo, está al alcance de todos, es por eso, que para comunicar o generar contenido, no necesitas tanto equipo ni producción como en la Tv" (14yt-2ka).

Perder el miedo y soltarse (15yt-2ka)

"Al principio, me daba vergüenza o pensaba que no iba a generar interés por lo que quiero comunicar, pero es cuestión de perder el miedo y soltarte, al final de cuentas si tú crees que tu contenido es de valor, va a servir y vas a tener seguidores, siempre y cuando hagas caso a lo que la gente pide y necesite de acuerdo a tu rubro" (15yt-2ka).

Ver tutoriales de otros youtubers (16yt-2ka)

"Bueno lo más loco, es que yo no sigo o no tengo referentes de canales de pastelería, pero lo que sí hago es seguir estilos, por ejemplo, del canal "Mis pastelitos". Luego, a veces me pongo a ver tutoriales de diferentes youtubers a nivel mundial" (16yt-2ka). 


\section{Codificación abierta yt-1v}

Tipo de informante: Youtuber

Nombre y apellido del informante: Víctor Goya

Código: yt-1v

Preguntas que orientan la codificación abierta

\section{Pregunta principal de investigación}

¿De qué manera los youtubers con más vistas en el Perú constituyen una modalidad emergente de producción audiovisual en la era digital?

\section{Preguntas específicas de investigación}

- ¿Cuáles son los distintos medios de producción audiovisual en la era digital?

- ¿Cómo se caracteriza el fenómeno youtubers desde una perspectiva comunicacional?

- ¿Cuáles son los youtubers con más vistas en el Perú?

- ¿De qué manera influyen los youtubers como modalidad emergente de producción audiovisual en la era digital?

\begin{tabular}{|c|c|}
\hline Entrevista & Categorías \\
\hline $\begin{array}{l}\text { 1. ¿Consideras que hay diferencias } \\
\text { entre la televisión y YouTube? ¿Cuáles } \\
\text { crees que son las principales } \\
\text { diferencias? } \\
\text { Sí existen diferencias, en cuanto a } \\
\text { interacción medio-viewer, la evaluación } \\
\text { de métricas es más exacta que en la tv, la } \\
\text { elección de a qué hora, y cuando ver un } \\
\text { video de YouTube, frente a los horarios } \\
\text { fijos de la tv. El Youtuber no está } \\
\text { necesariamente presionado por el } \\
\text { auspiciador, por lo que tiene mayor } \\
\text { libertad de acción. (1) } \\
\text { 2. ¿Consideras a YouTube un medio } \\
\text { emergente? ¿Por qué? } \\
\text { Entre emergente y a ser parte de los } \\
\text { medios tradicionales de comunicación. } \\
\text { Los medios tradicionales, ya están } \\
\text { considerando a Youtube como medio de } \\
\text { información, incluso están empezando a } \\
\text { interactuar con él, tal es el caso de } \\
\text { Andysane y Latina Tv (2) }\end{array}$ & $\begin{array}{l}\text { Diferencia entre YouTube y la } \\
\text { televisión (1yt-1v) } \\
\text { "Sí existen diferencias, en cuanto a } \\
\text { interacción medio-viewer, la evaluación } \\
\text { de métricas es más exacta que en la tv, la } \\
\text { elección de a qué hora, y cuando ver un } \\
\text { video de YouTube, frente a los horarios } \\
\text { fijos de la tv. El Youtuber no está } \\
\text { necesariamente presionado por el } \\
\text { auspiciador, por lo que tiene mayor } \\
\text { libertad de acción" (1yt-1v). } \\
\text { Complementación entre YouTube y } \\
\text { medios tradicionales (2yt-1v) } \\
\text { "Entre emergente y a ser parte de los } \\
\text { medios tradicionales de comunicación. } \\
\text { Los medios tradicionales, ya están } \\
\text { considerando a Youtube como medio de } \\
\text { información, incluso están empezando a } \\
\text { interactuar con él, tal es el caso de } \\
\text { Andysane y Latina Tv" (2yt-1v). }\end{array}$ \\
\hline
\end{tabular}


3. ¿De qué manera crees que han impactado los youtubers en el público en general, respecto a los medios tradicionales?

La torta está inclinándose a favor de Youtube. Pero los medios tradicionales siguen teniendo mayor credibilidad. (3)

4. Para comunicar tus ideas y proyectos, ¿qué plataformas digitales utilizas y cómo las utilizas?

Youtube para mis videos e Instagram. (4) 5. ¿Qué sensaciones o emociones buscas generar en tu público objetivo?

Risa, en algunos casos indignación. (5)

6. ¿Es posible para un youtuber profesionalizarse en su trabajo, tanto en lo económico como en los aspectos técnicos, sin correr el riesgo de perder lo que atrae a su público de este medio? Claro que sí, siempre y cuando no pierda el sentido de su contenido. (6)

7. Ahora cerremos con unas preguntas más personales. ¿Por qué decidiste ser youtuber?

Porque mi cabeza es un amasijo de ideas que necesitan salir (7)

8. ¿Te consideras un influencer? ¿Cuál es la diferencia entre un influencer y un youtuber?

Todos somos influencers. Un youtuber simplemente es una persona que tiene un canal de Youtube. Pero si la persona por sí misma, no llega a persuadirte para algo en específico, entonces no es influencer. Ejemplo: un canal de YouTube que muestra a su perro comiendo, sin contexto alguno y sin ningún fin.

9. ¿Cuáles son tus referentes en YouTube, tanto a nivel nacional como internacional y por qué?

Nigahiga, porque es chévere, lo he visto desde sus inicios cuando no tenía nada, era pura creatividad y he sido testigo de cómo fue creciendo.

10. ¿Cómo crees que será el futuro de YouTube?

Crecerá o será comprado por otra empresa, con internet todo es incierto.
Hegemonía digital Vs credibilidad tradicional (3yt-1v)

"La torta está inclinándose a favor de Youtube. Pero los medios tradicionales siguen teniendo mayor credibilidad" (3yt1v).

Combinación de medios digitales (4yt1v)

"Youtube para mis videos e Instagram" (4yt-1v).

Intencionalidad del Youtuber (5yt-1v)

"Risa, en algunos casos indignación" (5yt-1v).

Profesionalización de youtuber (6yt-1v) "Claro que sí, siempre y cuando no pierda el sentido de su contenido" (6yt-1v).

Inspiración personal del youtuber (7yt1v)

"Porque mi cabeza es un amasijo de ideas que necesitan salir" (7yt-1v).

Youtuber especializado y ético (8yt-1v)

"Todos somos influencers. Un youtuber simplemente es una persona que tiene un canal de Youtube. Pero si la persona por sí misma, no llega a persuadirte para algo en específico, entonces no es influencer. Ejemplo: un canal de YouTube que muestra a su perro comiendo, sin contexto alguno y sin ningún fin" (8yt-1v).

\section{Youtuber chévere y creativo (9yt-1v)}

"Nigahiga, porque es chévere, lo he visto desde sus inicios cuando no tenía nada, era pura creatividad y he sido testigo de cómo fue creciendo" (9yt-1v).

Incertidumbre de internet (9yt-1v)

"Crecerá o será comprado por otra empresa, con internet todo es incierto" (9yt-1v). 


\section{Codificación Axial y triangulación}

Subcategoría: Características de YouTube

\begin{tabular}{|l|l|l|}
\hline Aspectos & Características de YouTube & Medios tradicionales \\
\hline Información & $\begin{array}{l}\text { Diversa, segmentada y ajustada a } \\
\text { los requerimientos de los } \\
\text { usuarios }\end{array}$ & $\begin{array}{l}\text { Concebida para todos los } \\
\text { públicos }\end{array}$ \\
\hline $\begin{array}{l}\text { Participación de los } \\
\text { usuarios }\end{array}$ & $\begin{array}{l}\text { Productores y receptores de } \\
\text { contenidos }\end{array}$ & Receptor de contenidos \\
\hline $\begin{array}{l}\text { Elección de los } \\
\text { contenidos }\end{array}$ & El usuario elige el contenido & $\begin{array}{l}\text { El medio elige el } \\
\text { contenido }\end{array}$ \\
\hline $\begin{array}{l}\text { Posibilidades de } \\
\text { crecimiento }\end{array}$ & En plena expansión & $\begin{array}{l}\text { En proceso de } \\
\text { adaptación a la era } \\
\text { digital }\end{array}$ \\
\hline Interactividad & Total & Limitada \\
\hline $\begin{array}{l}\text { Complementariedad } \\
\text { con otros medios }\end{array}$ & Comunidad multiplataforma & $\begin{array}{l}\text { En proceso de } \\
\text { adaptación a la era } \\
\text { digital }\end{array}$ \\
\hline
\end{tabular}

Subcategoría: Hegemonía de medios de comunicación digital

\begin{tabular}{|l|l|l|}
\hline Aspecto & Medios digitales & Medios tradicionales \\
\hline Consumo del medio & $\begin{array}{l}\text { En fase de crecimiento, } \\
\text { elevada }\end{array}$ & En decrecimiento, baja \\
\hline $\begin{array}{l}\text { Participación de los } \\
\text { usuarios }\end{array}$ & $\begin{array}{l}\text { Receptores, electores y } \\
\text { productores de contenidos }\end{array}$ & $\begin{array}{l}\text { El medio determina los } \\
\text { contenidos }\end{array}$ \\
\hline Cadena medio- empresas & En fase de crecimiento & En decrecimiento \\
\hline Proyección futura & Liderazgo de los millenials & $\begin{array}{l}\text { En proceso adaptativo a la } \\
\text { era digital }\end{array}$ \\
\hline $\begin{array}{l}\text { Confiabilidad de la } \\
\text { información }\end{array}$ & Baja & Elevada \\
\hline Economía de medios & Bajos costos & $\begin{array}{l}\text { Insostenibilidad de los } \\
\text { costos }\end{array}$ \\
\hline
\end{tabular}

